\title{
THE ROLE OF SENSE OF COHERENCE IN STRESSOR APPRAISAL
}

\section{By}

Lisa Lynn Brady

Christopher J. L. Cunningham

UC Foundation Professor of Psychology (Chair)

David E. Ferrier

Assistant Professor of Psychology

(Committee Member)
Brian. J. O’Leary

Associate Professor of Psychology

(Committee Member) 


\section{THE ROLE OF SENSE OF COHERENCE IN STRESSOR APPRAISAL}

By

Lisa Lynn Brady

A Thesis Submitted to the Faculty of the University of

Tennessee at Chattanooga in Partial

Fulfillment of the Requirements of the Degree of

Master of Science: Psychology

The University of Tennessee at Chattanooga

Chattanooga, Tennessee

May 2017 
Copyright (C) 2017

By Lisa Lynn Brady

All Rights Reserved 


\begin{abstract}
According to the transactional theory of stress, cognitive individual differences impact stressor appraisal. Sense of Coherence (SoC) refers to an individual's generalized perception of environmental stimuli. Individuals with a strong SoC perceive the world as more comprehensible, manageable, and meaningful and may be more likely to appraise work-related stressors as having potential for opportunities (challenges) than for obstructing personal gain (hindrances) or causing harm (threats). This study assessed the role of SoC in the appraisal of work-related stressors as challenges, hindrances, and threats. Although an individual's SoC remains relatively stable upon reaching adulthood, there is a positive association between age and SoC across the lifespan. This study examined the moderating effect of age on the relationship between SoC and stressor appraisal. Two statistical techniques were applied, with one set of results supporting the hypothesis and the other set revealing significant relationships between stressor appraisal tendencies and the three SoC subdimensions.
\end{abstract}




\section{ACKNOWLEDGMENTS}

I would especially like to thank my parents for their endless love and support throughout my academic career, and I want to thank my family and friends for their help and generosity. I would also like to thank my thesis chair, Dr. Chris Cunningham, for his constant guidance, encouragement, and dedication in helping me with this project. Thank you to Dr. Amanda Clark for her mentorship and to my committee members, Dr. Brian O'Leary and Dr. David Ferrier, for generously sharing their knowledge and offering advice throughout the process. I would like to thank all those who have contributed to this area of research and to those who are dedicated to improving occupational health and well-being. Finally, I am grateful to each of my amazing classmates, who have inspired and supported me along this journey. 


\section{TABLE OF CONTENTS}

ABSTRACT

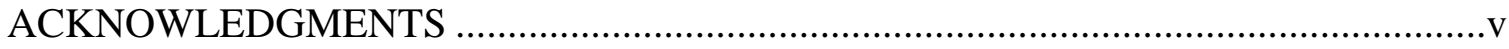

LIST OF TABLES ............................................................................................ vii

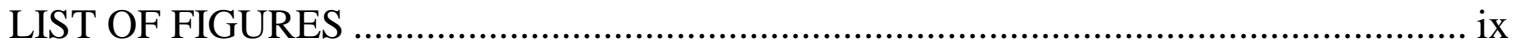

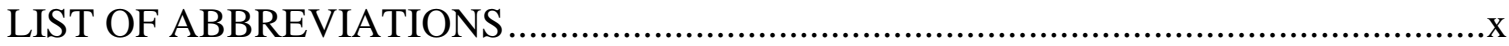

LIST OF SYMBOLS ………………………........................................................ xii

\section{CHAPTER}

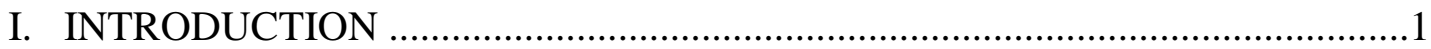

Appraising Stressors: Challenges, Hindrances, Threats? .....................................1

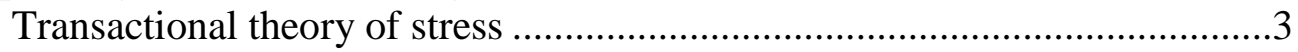

Measuring stressor appraisal .....................................................................

Challenge, hindrance, and threat appraisal ...............................................6

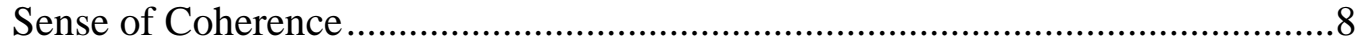

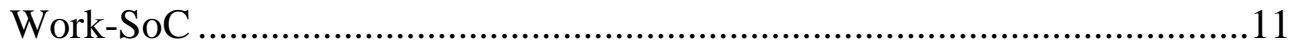

The Present Study ……………………..........................................................

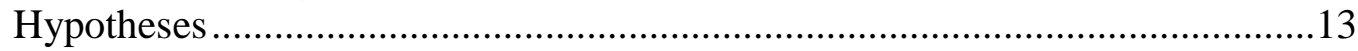

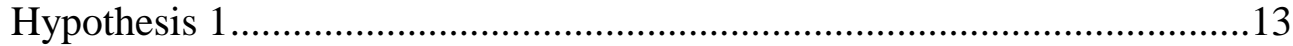

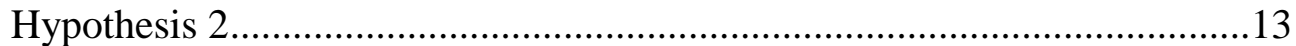

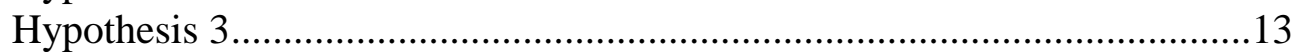

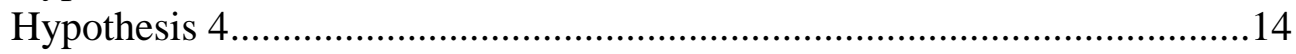

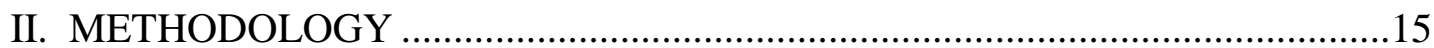

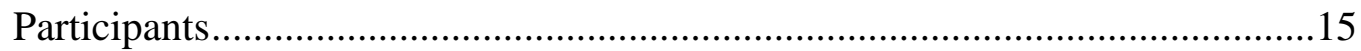

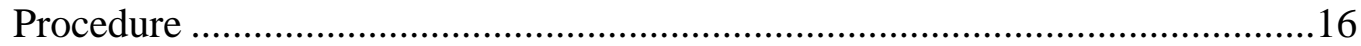

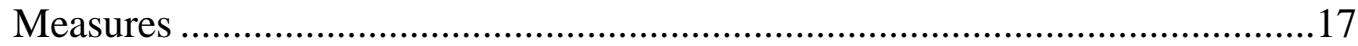

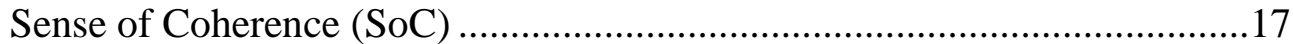

Work-Related Sense of Coherence (Work-SoC) …......................................18

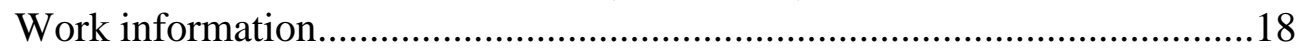

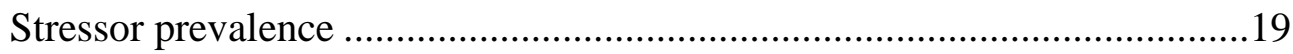




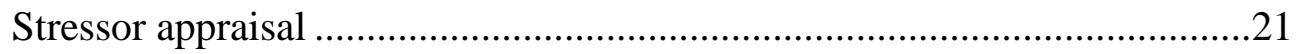

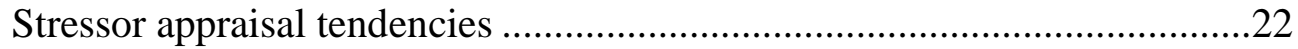

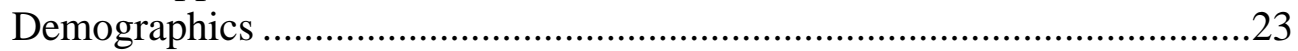

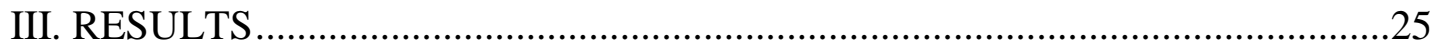

Hypothesis Tests .........................................................................................28

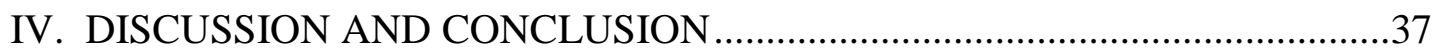

Limitations and Future Research ....................................................................40

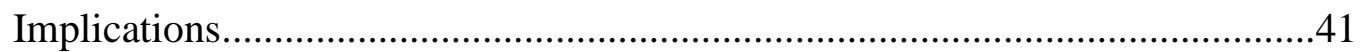

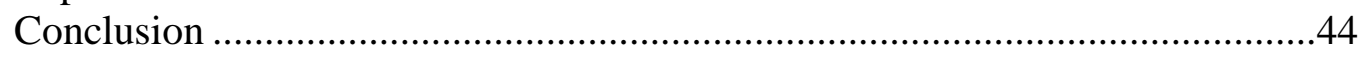

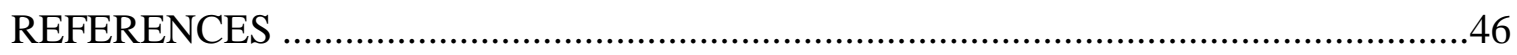

APPENDIX

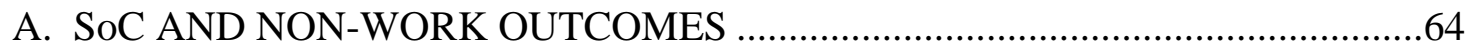

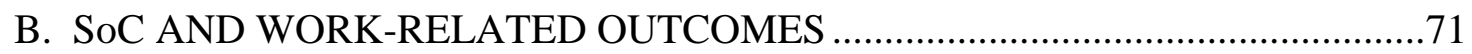

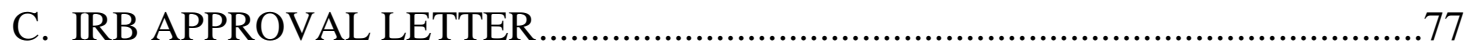

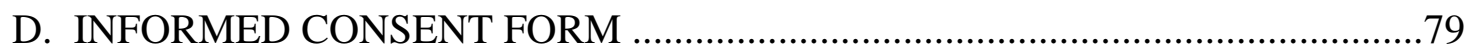

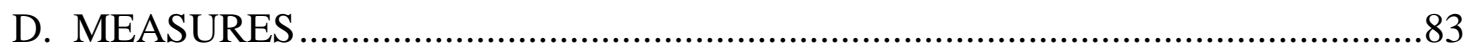

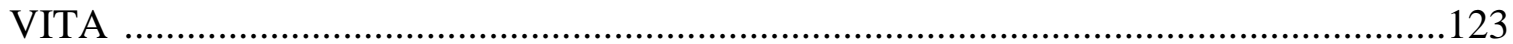




\section{LIST OF TABLES}

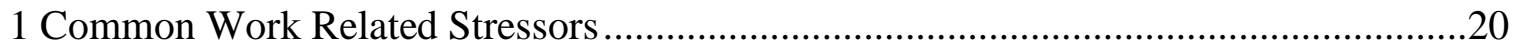

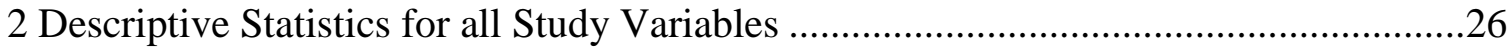

3 Intercorrelations between all Study Variables ....................................................2

4 Measurement Model of Fit Statistics without Covariates...........................................32

5 Measurement Model of Fit Statistics with Covariates ................................................32

6 Factor Correlations for Five Factor (2b) and Five Factor + General Factor (2c)

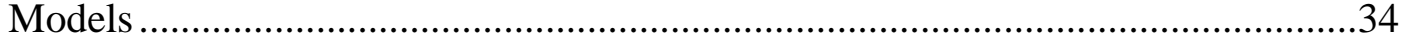

7 Factor Correlations for Seven Factor (2d) and Seven Factor + General Factor (2e) Models .....

8 Challenge, Hindrance, and Threat Appraisals Explained by Age and Sense of

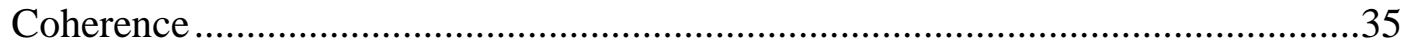

9 Challenge, Hindrance, and Threat Appraisals Explained by Age and Work-SoC .........36 


\section{LIST OF FIGURES}

1 Conceptual Model of Hypotheses 1 through 4 ............................................................13

2 Conceptual Model of ESEM Analysis of Factor Correlations for and Five Factor + General Factor Model (2c) ............................................................................

3 Conceptual Model of ESEM Analysis of Factor Correlations for and Seven Factor + General Factor Model (2e) ............................................................................

4 Relationship between Challenge Appraisal and Work-SoC Moderated by Age .............40 


\section{LIST OF ABBREVIATIONS}

H1, Hypothesis 1

$\mathrm{H} 2$, Hypothesis 2

H3, Hypothesis 3

$\mathrm{H} 4$, Hypothesis 4

SoC, Sense of Coherence

Work-SoC, Work-Related Sense of Coherence

NIOSH, National Institute for Occupational Safety and Health

BLS, Bureau of Labor Statistics

SD, Standard Deviation

IRB, Institutional Review Board

USA, United States of America

SoC-29, 29-Item Sense of Coherence Scale

OLQ, Orientation to Life Questionnaire

SoC-C, Comprehensibility

SoC-Ma, Manageability

SoC-Me, Meaningfulness

ESEM, Exploratory Structural Equation Modeling

CFA, Confirmatory Factor Analysis

EFA, Exploratory Factor Analysis 
SEM, Structural Equation Modeling

$d f$, Degrees of Freedom

AIC, Akaike Information Criterion

BIC, Bayesian Information Criterion

RMSEA, Root Mean Square Error of Approximation

CI, Confidence Interval

CFI, Comparative Fit Index

TLI, Tucker-Lewis Index

SRMR, Standardized Root Mean Square Residual 


\section{LIST OF SYMBOLS}

$\alpha$, Cronbach's alpha

$N$, Total number of cases

$r$, Estimate of Pearson product-moment correlation coefficient

$M$, Mean

$p$, Probability

$\chi^{2}$, Chi square

Adj. $R^{2}$, adjusted proportion of variance accounted for in a multiple regression

$F$, the ANOVA test statistic 


\section{CHAPTER I}

\section{INTRODUCTION}

Occupational stress researchers have long acknowledged that work-related stress can negatively impact physical and psychological health, employee attitudes, and work behaviors

(e.g., Jex \& Yankelevich, 2008), but a growing number of studies indicates that the impact of stress is not always consistently bad (Lepine, Podsakoff, \& Lepine, 2005; Podsakoff, LePine, \& LePine, 2007). Work stressors can positively or negatively impact work-related psychological and behavioral outcomes (e.g., motivation and actual job-related performance), even while being detrimental to personal physical health if chronic and persistent. The present study focused one mechanism by which these inconsistencies may be at least partially explained. Specifically, this study examined how the appraisal of work-related stressors may be influenced by a potent form of psychological individual difference known as Sense of Coherence (SoC).

\section{Appraising Stressors: Challenges, Hindrances, Threats?}

The notion that personal experiences with stress can be positive and/or negative is typically traced back to the concepts of eustress and distress, respectively (Selye, 1974). More recent work in this area suggests that stressors and the resulting experienced stress may take both positive and negative forms, as challenges and hindrances (Cavanaugh, Boswell, Roehling, \& Boudreau, 2000). Within this model, common challenge stressors include demands such as high workload, time pressure, job scope, and high responsibility; employees tend to view these 
demands as creating a challenge and/or opportunity for personal development and achievement. In contrast, hindrance stressors include demands such as organizational politics or bureaucracy, role ambiguity, and concerns related to job security; employees tend to view these demands as obstacles to task accomplishment and personal growth (Cavanaugh et al., 2000). Challenge stressors have been positively associated with job satisfaction (Beehr, Glaser, Canali, \& Wallwey, 2001; Podsakoff et al., 2007), organizational loyalty (Boswell, Olson-Buchanan, \& LePine, 2004), performance (Lepine et al., 2005; Pearsall, Ellis, \& Stein, 2009), and retention (Podsakoff et al., 2007), whereas hindrance stressors have been negatively associated with these outcomes.

Recent research employing the challenge-hindrance perspective on work stressors often treats specific stressors as either inherently challenging or hindering, leading to the assumption that everyone interprets stressors as they are categorized in the research. However, little attention has been paid to the stressor appraisal process since the introduction of the taxonomy. To initially determine the categorization of certain stressors, Cavanaugh et al. (2000) jointly labelled 11 stressors as either challenges or hindrances and then requested four individuals ( 3 students and 1 professor) to report how they would appraise each stressor. Although the evaluators' categorization of the stressors agreed with the researchers' categorization in $93 \%$ of the cases, this method involved assumptions about how individual stressors are interpreted within a larger population (Cavanaugh et al., 2000). Instead, the challenge and hindrance appraisals of research participants themselves must be examined. While the challenge-hindrance stressor framework presents an improvement over previous and more simplistic attempts to create a taxonomy of stressors, it overlooks the role of individual differences in how individuals actually appraise different stressors. This is surprising given that the challenge-hindrance stressor model draws 
heavily from the transactional theory of stress (Lazarus \& Folkman, 1984), which emphasizes that an individual's appraisal of a stressor plays a crucial role in that individual's ultimate stress experience.

Transactional theory of stress. The most dominant framework for explaining the cognitive stressor appraisal process is Lazarus and Folkman's (1984) work with the transactional theory of stress. Stress results from a transaction between the environment and the individual, including the individual's perceptions, expectations, and coping behaviors. Central to the transactional theory of stress is the idea of cognitive appraisal, which involves an evaluative perception that one's well-being is implicated in the person-environment transaction (Lazarus \& Folkman, 1984). Within the theory, Lazarus and Folkman identify two types of cognitive appraisal: primary appraisal and secondary appraisal.

Primary appraisal involves the initial evaluation of the significance of an encounter or transaction for a specific individual, and secondary appraisal involves the evaluation of one's capacity to cope with the situation (Lazarus \& Folkman, 1984). They proposed that primary appraisals of stress can take three forms: (1) harm or loss already experienced; (2) the threat of future harm or loss, known as threat appraisal; or (3) the potential for mastery and gain, known as challenge appraisal. Following an individual's primary appraisal of a stressor, a secondary appraisal ensues in which the individual assesses what, if anything, can be done to improve the potential for benefits or prevent harm (Lazarus \& Folkman, 1984). Thus, secondary appraisal involves the evaluation of various coping options (e.g., altering the situation, accepting the situation, seeking more information, or holding back from acting in a counterproductive 
manner). Although secondary appraisal is part of the transactional theory, the focus in the present study is on the primary appraisal processes.

Regarding the role of primary appraisal in the transactional theory of stress, Lazarus and Folkman (1984) proposed that an individual can simultaneously perceive that a situation provides opportunities for mastery or growth (challenge appraisal) and opportunities for harm or loss (threat appraisal). Therefore, they emphasized the importance of measuring and understanding the extent to which an individual appraises the same situation as both a challenge and a threat (Lazarus \& Folkman, 1984). In support of the transactional theory, recent research has demonstrated that stressors can be appraised along both dimensions simultaneously.

Several work-related stressors have been perceived as a challenge in one study, a hindrance in another study, and as both a challenge and a hindrance simultaneously. For example, workload is considered a challenge stressor in the management literature and has been linked to increases in job performance (Cavanaugh et al., 2000). However, other studies have shown that it can be perceived as a hindrance stressor, specifically in occupations in which the individual cares for others (Bakker \& Sanz-Vergel, 2013; Drach-Zahavy \& Freund, 2007), or that it can be appraised as both a challenge and a hindrance stressor (Webster, Beehr, \& Love, 2011). Webster and colleagues (2011) also demonstrated that role ambiguity and role conflict, considered hindrance stressors in previous stressor frameworks, can be appraised as both challenge and hindrance stressors. Similarly, time pressure has been appraised as both a challenge and a hindrance stressor (Searle \& Auton, 2015) and is associated with both positive and negative well-being (Widmer, Semmer, Kälin, Jacobshagen, \& Meier, 2012). While studies using the challenge-hindrance stressor framework have begun to demonstrate that stressors can be classified into more than one category simultaneously, many researchers continue to overlook 
the vital issue of how and why this is possible. Within the transactional theory of stress, one possibility is through the process of individual cognitive appraisal of stressors.

Measuring stressor appraisal. Lazarus and Folkman (1984) stated that an individual's cognitive appraisal should mediate the effects of the demand on strain and other outcomes. Indeed, studies have shown that the relationships between stressors and strains and between stressors and work-related outcomes are partially mediated by cognitive appraisal (Gomes, Faria, \& Gonçalves, 2013; Searle \& Auton, 2015; Webster et al., 2011). In addition to the effects of challenge and hindrance stressors, information about appraisals is useful in understanding affective states, coping behaviors, and task performance (Searle \& Auton, 2015). However, there is a general lack of empirical evidence about the role of individual cognitive appraisal among research involving the challenge-hindrance stressor framework.

Although the challenge-hindrance stressor framework draws heavily from the transactional theory of stress, much of the research using this model is inconsistent with the core element of Lazarus and Folkman's (1984) theory. Recent meta-analyses on the topic (Crawford, LePine, \& Rich, 2010; Podsakoff et al., 2007) indicate that many researchers have not directly measured participants' appraisals of stressors as challenges (i.e., having potential for mastery or growth) or hindrances (i.e., having potential for future harm or loss). Instead, stressors have been classified a priori by the researchers based on a majority of respondents classifying them in a certain way (see Cavanaugh et al., 2000) and/or based on the stressors' known relationships with certain outcomes. In other words, rather than recording participants' direct appraisal of specific stressors, researchers have asked participants to report either the experienced level of the work 
stressors (e.g., Lepine et al., 2005) or the amount of stress caused by stressors (e.g., Cavanaugh et al., 2000; LePine, LePine, \& Jackson, 2004).

This approach to stressor research applies pre-identified appraisal classifications and typically focuses on measuring either the prevalence of the stressor or the amount of stress arousal associated with a perceived stressor. Neither approach first directly measures whether a participant's appraisal of a stressor is actually of a challenge or threat form. This omission further perpetuates these theoretically, rather than empirically derived, stressor classifications. If common work-related stressors and other stimuli in a work environment can be appraised differently, either by different people in one context or by the same person in different contexts, then a priori categorization of stressors or stimuli should not be assumed to necessarily and accurately reflect an individual's appraisal of a stressor. Furthermore, prior to directly measuring an individual's appraisal of a stressor, distinctions must be made concerning more than just the two standard appraisal dimensions - indeed, there are three well-established and distinct forms of stressor appraisal that should be studied.

Challenge, hindrance, and threat appraisal. Lazarus and Folkman (1984) indicated that besides the appraisal of harm or loss already experienced, primary appraisal involves an individual's perception of a stressor as having potential for mastery or gain (challenge appraisal) and as having potential for future harm or loss (threat appraisal). In addition to these two forms of appraisal, Lazarus (1991) proposed a third type of primary appraisal, which involves frustration. Building on this idea, Tuckey and colleagues (2015) suggested that when the pursuit of a goal is blocked and frustration arises, this can be labeled as an additional form of primary appraisal, which they termed hindrance appraisal. In making this distinction, Tuckey et al. 
argued that the potential for stressors to threaten the self adds an important dimension to the existing challenge-hindrance stressor framework.

As stated previously, within the framework stressors appraised as challenges enhance a person's opportunities for meaningful gains, and those appraised as hindrances prevent, restrict, or obstruct opportunities for such gains. However, Tuckey and colleagues (2015) pointed out that the potential for a stressor to threaten oneself does not fit into the framework's descriptions of either challenge or hindrance. They noted that previous researchers (e.g.,Lepine et al., 2005, pp. 765, 767; Webster et al., 2011, p. 506) made assumptions by equating threat and hindrance, sometimes using "threat" or "threatening" in relation to hindrance stressors or the perception of hindrance (Tuckey et al., 2015). To distinguish threat stressors from the categories of challenge and hindrance stressors, Tuckey et al. (2015) drew upon Lazarus and Folkman's (1984) concept of threat appraisal and defined stressors appraised as threats to be "work-related demands or circumstances that tend to be directly associated with personal harm or loss" (p. 133). Ultimately, Tuckey et al. found that hindrance and threat were not only different categories of stressors but were also different categories of appraisals, thus providing empirical support for the differentiation among challenge, hindrance, and threat appraisals.

Although this distinction provides a starting place for future stress interventions, Tuckey et al. (2015) specifically noted that researchers should consider the mechanisms underlying the damaging effects of stress, such as how employees' personal resources influence the appraisal of work stressors. To understand how and why individuals appraise stressors in certain ways, it is critical to examine cognitive individual differences. Research on the appraisal of stressors as challenge, hindrance, or threat is still in its infancy; thus, there are few studies assessing the role that individual differences play in employees' cognitive appraisals of work-related stressors. 
What is clear so far, is that people do differ in how they perceive, appraise, and respond to stressors. It is likely that these differences are due in large part to underlying differences in how individuals cognitively process stimuli that may become stressors and therefore trigger stress events (Lazarus \& Folkman, 1984). What is not clear yet is which specific cognitive factors matter most for their influence over the primary appraisal processes detailed in the preceding material. However, one cognitive factor of particular relevance is a person's sense of coherence (SoC; Antonovsky, 1987b).

\section{Sense of Coherence}

The present study was designed to focus on one such cognitive individual difference, a person's SoC, and its role in stressor appraisal. This study, therefore, builds on previous work (e.g., Searle \& Auton, 2015; Tuckey et al., 2015; Webster et al., 2011) by directing attention to how an individual's level of SoC may influence their appraisal of a stressor as a challenge or hindrance. While there is little doubt that cultural and social structures play a significant role in shaping individuals' thoughts, feelings, and behaviors, Lazarus and Folkman (1984) insisted that these variables alone cannot account fully for how people appraise stressors; the private thoughts and feelings that make up one's social reality can differ greatly from individual to individual. The complex stressor appraisal process is influenced by a number of individual differences that shape cognitive perceptions in every situation (Lazarus \& Folkman, 1984).

Of direct relevance to this line of inquiry is Antonovsky's (1979, 1987b) work on the SoC construct and theory. He referred to SoC as an individual's generalized emotional-cognitive perception of stimuli in the environment. Antonovsky $(1987 \mathrm{~b}, 1991,1993)$ proposed that SoC is a broadband health resource, rather than a particular coping style or specific personality trait, 
which influences an individual's perceptions and coping behavior. It is a global orientation through which an individual perceives life as comprehensible, manageable, and meaningful. SoC is defined as:

a global orientation that expresses the extent to which one has a pervasive, enduring, though dynamic, feeling of confidence that (1) the stimuli deriving from one's internal and external environments in the course of living are structured, predictable, and explicable (comprehensibility); (2) the resources are available to meet the demands posed by the stimuli (manageability); and (3) these demands are challenges, worthy of investment and engagement (meaningfulness) (Antonovsky, 1987b, p. 19).

SoC is associated with a wide variety of general health and well-being indicators, as demonstrated by a vast amount of research across multiple disciplines (see summary in Appendix A). For example, studies have shown that $\mathrm{SoC}$ is significantly and negatively related to anxiety and depression (Schnyder, Buchi, Sensky, \& Klaghofer, 2000), cancer (Poppius, Virkkunen, Hakama, \& Tenkanen, 2006), diabetes (Kouvonen et al., 2008), and mortality (Super, Verschuren, Zantinge, Wagemakers, \& Picavet, 2014; Wainwright et al., 2008), and positively related to general health and well-being (Binkowska-Bury \& Januszewicz, 2010; Feldt, 1997; Geyer, 1997; Kivimaki, Feldt, Vahtera, \& Nurmi, 2000; Pallant \& Lae, 2002), resilience (Hart, Wilson, \& Hittner, 2006), and quality of life (Eriksson \& Lindstrom, 2007; Pusswald et al., 2012; Tartas, Walkiewicz, Budzinski, Majkowicz, \& Wojcikiewicz, 2014).

Rather than approach health from a pathogenic perspective, which focuses on the origin of disease, Antonovsky (1979) developed a salutogenic theory, which places emphasis on the origin of health and staying well (e.g., why certain individuals are able to successfully cope with stressors) (Antonovsky, 1979, 1985, 1987b). He claimed that an individual's state of health is not 
a dichotomy of health or disease, but is instead a continuum ranging from ease to disease throughout the course of one's life. SoC is a central variable in explaining an individual's movement toward the healthy end of this continuum (Antonovsky, 1987b). The central tenet in this theory is that individuals with a stronger overall SoC have a greater capacity for coping with stressors in a healthy manner (Antonovsky, 1987a). As such, SoC has been found to impact individuals' appraisal of stressful events, although seemingly without one's conscious awareness (Amirkhan \& Greaves, 2003). Due to differences in one's perception of the comprehensibility, manageability, and meaningfulness of stimuli in the environment, the impact of stressful experiences may vary for individuals depending on their SoC (Bolger \& Zuckerman, 1995; Cooper, 2001).

Antonovsky $(1979,1987 b, 1993)$ referred to SoC as a relatively stable disposition that is shaped by a person's life experiences in childhood, adolescence, and early adulthood (e.g., marriage, work, lifestyle, set of social roles; Antonovsky, 1987b). Although SoC was once thought to be stable by the age of 30 , this early idea has been challenged by a number of more recent longitudinal studies (e.g., Feldt, Leskinen, Kinnunen, \& Mauno, 2000; Hakanen, Feldt, \& Leskinen, 2007; Smith, Breslin, \& Beaton, 2003). SoC is not necessarily fixed in adulthood; it has a dynamic nature and may change for individuals throughout the course of life as a result of major adaptations or development efforts in attempt to strengthen one's SoC (Antonovsky, 1979, 1987b, 1991). Antonovsky (1987b) theorized that, as in other significant life contexts, the work environment can contribute significantly to an individual's SoC.

In the workplace, consistent daily experiences enhance one's sense of comprehensibility, balancing of workload enhances manageability, and participation in socially valued decisionmaking enhances meaningfulness (Antonovsky, 1979, 1987b, 1991). Within the context of the 
workplace, general SoC has proven to be a valuable construct. Many studies have shown the influences of the work environment on its manifestation (see summary in Appendix B). Empirical evidence reveals that $\mathrm{SoC}$ (a) is influenced by different aspects of the workplace, (b) influences work-related outcomes, and (c) moderates the effects of adverse working conditions on health outcomes (Jenny, Bauer, Vinje, Vogt, \& Torp, 2016).

Work-SoC. A coherent work experience is relevant to both the general SoC of employees and their appraisals of work-related stressors. Although Antonovsky (1979) viewed $\mathrm{SoC}$ as a non-context specific element in the makeup of an individual, he acknowledged that a context-based SoC replaces a purely individual perspective and refers to one's experiences dealing with external stimuli, challenges, and threats. A context-specific SoC can take into account one's social environment and the meaning of situational transactions (Antonovsky, 1979). Several authors have redefined SoC as a flexible and context-specific construct. Antonovsky and Sourani (1988) identified the construct of family SoC, which is the perceived coherence of family life; Artinian (1997) discussed situational SoC, which reflects one's present and specific orientation rather than a global life orientation; and Gräser (2003) developed a scale to measure university SoC, which is the extent to which university staff perceive their work situation as coherent. As such, it is reasonable to at least consider using a contextualized version of SoC when trying to understand its impact in a work-specific environment.

Bauer and Jenny (2007) proposed a work context-specific application of SoC, (Work$\mathrm{SoC}$ ), as a way to measure coherent work experiences. Work-SoC extends from the traditional framework for measuring SoC and focuses on an individual's current work situation. As contextualized within the Work-SoC model: (a) comprehensibility refers to the extent to which 
employees perceive a work environment as ordered, predictable, and understandable; (b)

manageability refers to the extent to which employees recognize available resources and have access to use them to cope with workplace demands; and (c) meaningfulness refers to the extent to which employees view the work environment to have importance and value, and that it is worthwhile to engage in dealing with workplace challenges (Bauer \& Jenny, 2007). This is a very new construct in the literature, but already there is some evidence to support its value and utility within occupational stress research. Eberez, Becker, and Antoni (2015) interpreted WorkSoC as an individual meta-resource that moderates the work-health relationship by reducing the pathogenic effects of work stressors. Eberez et al. (2015) found evidence that Work-SoC appears to be a stronger predictor for work-related stress than global SoC.

\section{The Present Study}

Antonovsky (1984) stated that a strong SoC plays a significant role in influencing a person's tendency to appraise unavoidable stimuli as opportunities rather than stressors. Building on the theoretical and empirical work presented above, the present study examined the possible influence of general and work-specific SoC on individuals' appraisals of common work-related stressors as challenges, hindrances, and threats. Individuals with a high SoC tend to experience environmental stimuli in a way that enables them to perceive life events as coherent (Antonovsky, 1987b). This may lead to the perception of a more favorable working environment and the appraisal of stressors as challenges rather than hindrances or threats. The present study tested for the first time how the individual cognitive difference of SoC is associated with one's primary appraisal of common work stressors. Specifically, the present study tested the relationships illustrated in Figure 1. 


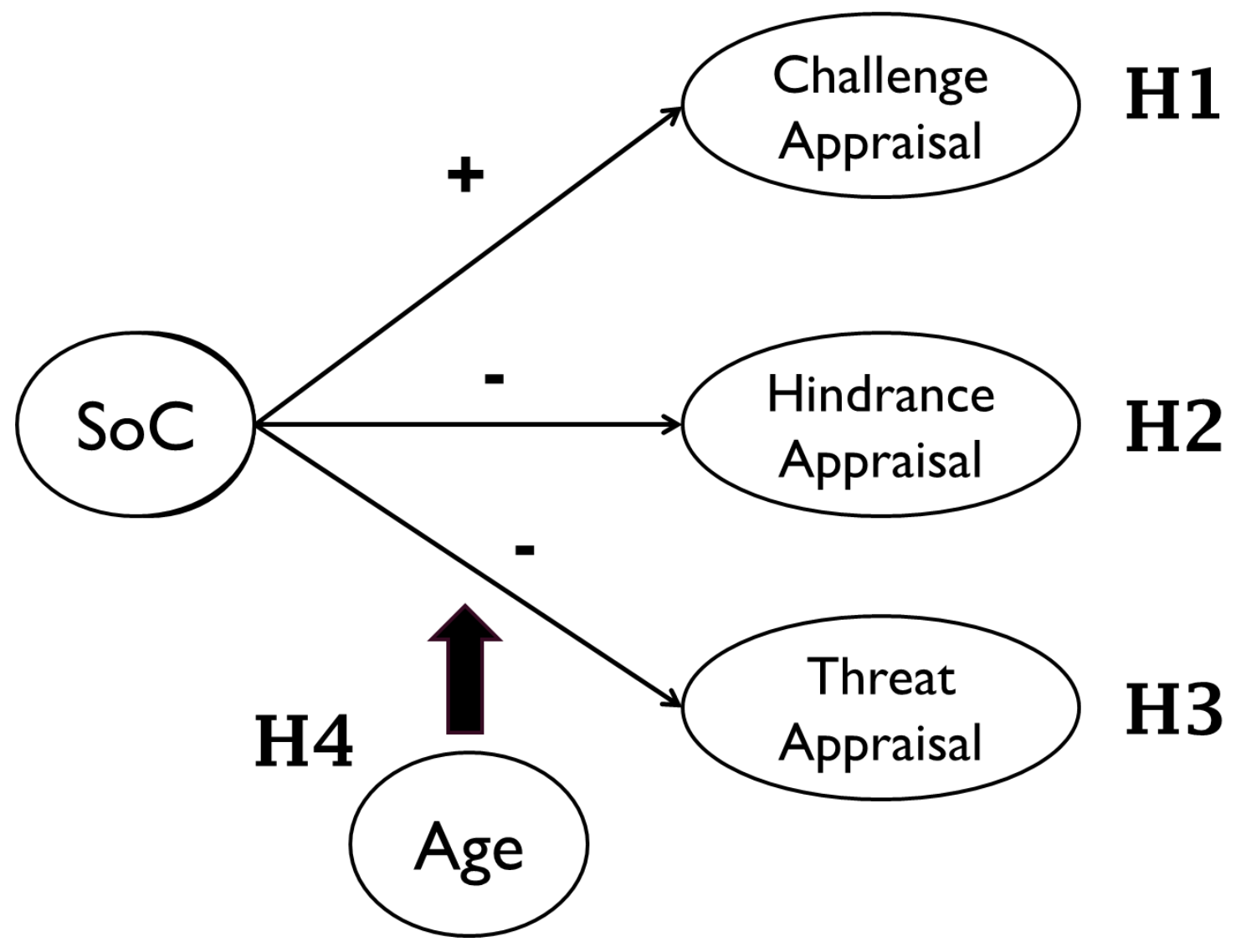

Figure 1 Conceptual Model of Hypotheses 1 through 4

Hypotheses. Extending from the preceding figure and discussion, the following hypotheses were tested using various operationalizations of appraisal tendencies (as detailed in the Method section):

Hypothesis 1: There is a positive relationship between $\mathrm{SoC}$ and tendency to appraise work stressors as challenges.

Hypothesis 2: There is a negative relationship between $\mathrm{SoC}$ and tendency to appraise work stressors as hindrances.

Hypothesis 3: There is a negative relationship between SoC and tendency to appraise work stressors as threats. 
Antonovsky (1987) predicted that SoC develops until about the age of 30, at which point it becomes relatively stable until retirement, after which a decrease is expected. However, this assumption has not found much support in subsequent empirical research. SoC seems to be relatively stable over time, but not as stable as Antonovsky assumed. Research shows that SoC steadily increases with age over the entire life cycle (Feldt et al., 2000; Nilsson, Leppert, Simonsson, \& Starrin, 2010). In a longitudinal study with more than 18,000 Finnish respondents, SoC was shown to develop over time, continuously increasing with age (Feldt et al., 2011). Additionally, in a population-based, five-year follow-up study of 43,500 Swedish respondents aged 18-85, Nilsson and colleagues (2010) demonstrated that SoC increases with age in men and women. In the present study, it was anticipated that less stability in SoC among younger individuals would likely result in less clear and therefore weaker relations between SoC and cognitive appraisal in comparison to SoC among older individuals. Specifically,

Hypothesis 4: The relationships between SoC and stressor appraisals (H1-H3) are moderated by age, such that they are stronger for older individuals than for younger individuals.

Finally, as an important note to the preceding hypotheses, Antonovsky (1987) proposed that life experiences that shape SoC are characterized by consistency, participation in shaping outcomes, and balance. Due to the numerous life experiences that may be characterized in this way, in the present study the analyses testing the preceding hypotheses included certain variables due to their potential confounding effect on the relationships that were the focus of this research. Specifically, the covariates were: sex, marital status, race, ethnicity, number of children, number of dependents, social support, tenure in current position, number of years working full-time, and highest level of education. 


\section{CHAPTER II}

\section{METHODOLOGY}

\section{Participants}

To ensure a basic level of exposure to common work-related stressors, participants for this study were either full-time graduate students with additional paid work responsibilities beyond classwork (e.g., Graduate/Teaching/Research Assistantship, Internship, part-/full-time work) or adults who were full-time employees working at least 34 hours per week (Bureau of Labor Statistics [BLS], 2016). Individuals who did not meet these inclusion criteria were excluded. Approximately 1876 potential participants were contacted and a total of 859 at least partially responded to the survey (45.8\% response rate). After applying the inclusion/exclusion rules just described, removing respondents who completed less than $50 \%$ of the survey, and excluding respondents who did not provide critical demographic information, the final sample for analysis included 591 mostly complete survey records (response rate against overall target sample $=31.5 \%$ ). All reported statistics past this point are based on this final sample.

Respondents ranged in age from 19-77 years, and the mean age was 36.31 years old (SD $=13.26)$. Of the respondents, $86.3 \%$ were full-time workers and $22 \%$ were full-time graduate students with paid work responsibilities in addition to school. Female respondents made up $68.1 \%$ of the sample, $27.5 \%$ of respondents indicated they were single adults, and $65.9 \%$ indicated they were married, living as married, or in a committed relationship. A majority of respondents identified their ethnicity as non-Hispanic (97.1\%). The most prevalent race 
represented in the sample was White (90\%), followed by Black/African American (4.7\%), Asian (1.2\%), Middle Eastern/Arab (1.0\%), and American Indian/Alaskan Native (0.3\%); $2.7 \%$ of respondents represented two or more races.

Forty percent of respondents reported that they had at least one child, and $46.1 \%$ of respondents reported that they were responsible for at least one other person. Approximately $72 \%$ of respondents had obtained a Bachelor's degree or higher, and the mean number of hours worked per week was $44.29(S D=11.65)$. Roughly $55 \%$ of respondents reported that they function as a supervisor of at least one other individual. The mean number of years that respondents had been working in their current position was $5.66(S D=7.54)$, and the mean number of years that respondents had been working full-time was $13.58(S D=12.93)$. If in need of social support, participants indicated they could talk to their: spouse (16.1\%), children (24.2\%), relative $(29.6 \%)$, close friend $(21.3 \%)$, neighbor $(6.4 \%)$, and coworker $(1.7 \%)$. Out of these six total social support options that respondents could have selected, the median response was three. Approximately $40 \%$ of respondents worked in the Education and Health Services industry, and $15 \%$ worked in the Professional and Business Services industry.

\section{Procedure}

The university's Institutional Review Board (IRB) approved this research study prior to data collection. Participants were asked to respond to a securely managed, web-based structured survey delivered through the Qualtrics internet-survey system. The survey required about 30 minutes to complete and was administered to samples recruited using the following strategies: (1) via emails to all graduate students at a medium-sized, public university in the southeastern United States of America (USA), (2) via a membership email list to a young professionals 
association, (3) via email list to the agency representatives of a community coalition, and (4) via direct and indirect personal appeal through professional social networking groups (e.g., LinkedIn, Facebook). No incentives were offered to encourage participation.

\section{Measures}

The data for this study were gathered using the measures detailed in this section. All measures are included in Appendix D along with a copy of the actual survey.

Sense of Coherence (SoC). Participants responded to the 29-item SoC scale (SoC-29), called the 'Orientation to Life Questionnaire' (OLQ) in its operational format (Antonovsky, 1993). The SoC-29 has been shown to be a reliable, valid, and cross culturally applicable instrument measuring how people manage stressful situations and stay well (Eriksson \& Lindstrom, 2005). The SoC model encompasses three components: comprehensibility (SoC-C), manageability (SoC-Ma), and meaningfulness (SoC-Me), which are measured with 11, 10, and 8 items, respectively. Previous research has supported the multidimensional factorial structure of the SoC-29 (Eriksson \& Lindstrom, 2005). Participants were instructed to respond to a variety of items along various rating scales all ranging from one to seven. An example is, "Do you have the feeling that you don't really care what goes on around you?", with responses ranging from $1=$ "Very seldom to never" to $7=$ "Very often". Higher scores on the measure indicate a strong SoC, which manifests itself through an individual's ability to perceive stressors as challenges rather than negative threats (Antonovsky, 1987b). Previous studies have shown high test-retest reliability for the SoC-29 measure (Feldt, Kivimaki, Rantala, \& Tolvanen, 2004; Feldt et al., 2000; Feldt, Leskinen, \& Kinnunen, 2005; Kivimaki et al., 2000; Schnyder et al., 2000). From a 
review of 124 previous studies, this measure has demonstrated adequate internal consistency reliability, with values ranging from $\alpha=.70$ to .95 for the items overall and for the items linked to each of the subdimensions (Eriksson \& Lindstrom, 2005). In the present study, the internal consistency reliability was $\alpha=.83$ for the overall SoC-29 and $\alpha=.79, .79$, and .83 for the three subdimensions (SoC-C, SoC-Ma, and SoC-Me), respectively.

Work-Related Sense of Coherence (Work-SoC). Bauer and Jenny (2007) proposed the concept of Work-SoC, which assumes that the participant's perception of comprehensibility, manageability, and meaningfulness is influenced by the interaction between individual characteristics and the characteristics of the work environment (Vogt, Jenny, \& Bauer, 2013). Based on Antonovsky's (1987b) definition of SoC, Bauer and Jenny (2007) extracted adjectives and added matched counterparts, forming a scale of nine bipolar items. Individuals responded to the question, "How do you personally find your current job and work situation in general?" by selecting the extent to which they agreed with the presented opposing adjectives on a seven-point scale. For example, one item displays the bipolar items "unmanageable" and "manageable" on opposite ends of the seven-point scale. Previous validation studies have demonstrated good internal consistency for these items, $\alpha=.83$ (e.g., Bauer, Vogt, Inauen, \& Jenny, 2015; Vogt et al., 2013) and have identified a three-factor structure of the scale with subdimensions of comprehensibility, manageability, and meaningfulness, and subdimension values ranging from $\alpha$ $=.72$ to .84 (Vogt et al., 2013). In the present study, the internal consistency reliability of the overall Work-SoC scale was $\alpha=.81$; subdimensions for this scale were not considered in the present study because of the limited number of items per dimension and the focus of the hypotheses being tested. 
Work information. Participants were informed that in this study, "work environment" refers to "the environment in which you are working for compensation or pay (e.g., part-/fulltime work, internship, graduate/teaching/research assistantship, clinical hours)". This definition was followed by a check item to assess participant understanding. The subsequent two items were used to gather participant information regarding job industry and job title. Job industry was categorized by the creation of ten industries from the United States Department of Labor.

Stressor prevalence. Although the research on work-related stress is vast, there is a subset of common or universal stressors that exists in a majority of work environments and appears in most research in this area (Wiegand et al., 2012). To reach a consensus in selecting practical psychosocial measures during the National Institute for Occupational Safety and Health (NIOSH) field investigations, an expert panel developed a taxonomy of psychosocial constructs. Panel members identified measures for each construct using existing taxonomies and criteria regarding the malleability, utility, and validity of constructs (Wiegand et al., 2012). The stressors were identified from the existing research and summarized in Table 1. For the present study, a comprehensive measurement item was formed for each of the 17 most commonly studied workrelated stressors. Participants were again provided with the definition of "work environment" and received the following instructions: "Indicate the percentage of time for which each of the following statements is true about your current 'work environment' (as defined above)." To measure the prevalence of the 17 stressors in a participant's workplace, each stressor was presented as a single item in first-person sentence format (e.g., "I have discretion in planning out my work and determining procedures in my work"). Participants were instructed to use a slider scale to indicate the prevalence of each of the 17 stressors in his or her work, with 0 indicating 
that a specific stressor occurred $0 \%$ of the time and 100 indicating that a specific stressor occurred $100 \%$ of the time.

Table 1 Common Work-Related Stressors

\begin{tabular}{|c|c|}
\hline Work-related stressor & Description \\
\hline Job autonomy & $\begin{array}{l}\text { Discretion in planning out the work and determining procedures } \\
\text { in the work (Hackman \& Oldham, 1980) }\end{array}$ \\
\hline $\begin{array}{l}\text { Participative decision- } \\
\text { making }\end{array}$ & $\begin{array}{l}\text { Input in the formulation of decisions for which one is responsible } \\
\text { for implementing (Lowin, 1968) }\end{array}$ \\
\hline Predictability of work & Unexpected events that occur at work (Tetrick \& LaRocco, 1987) \\
\hline Role ambiguity & $\begin{array}{l}\text { Unclear information concerning one's work objectives and what } \\
\text { is expected (Kahn, Wolfe, Quinn, Snoek, \& Rosenthal, 1964; } \\
\text { King \& King, 1990) }\end{array}$ \\
\hline Role conflict & $\begin{array}{l}\text { Conflicting information or inconsistent demands concerning } \\
\text { one's work or methods (Kahn et al., 1964; King \& King, 1990) }\end{array}$ \\
\hline $\begin{array}{l}\text { Quantitative work } \\
\text { overload }\end{array}$ & $\begin{array}{l}\text { Too much work to do in a given time frame (Spector \& Jex, } \\
\text { 1998) }\end{array}$ \\
\hline Qualitative work overload & The work is too difficult \& exceeds one's abilities (Fisher, 1993) \\
\hline $\begin{array}{l}\text { Quantitative work } \\
\text { underload }\end{array}$ & Not enough work to do (Fisher, 1993) \\
\hline $\begin{array}{l}\text { Qualitative work } \\
\text { underload }\end{array}$ & $\begin{array}{l}\text { The work is too simple and does not allow individuals to use their } \\
\text { full abilities. (Fisher, 1993) }\end{array}$ \\
\hline Responsibility for others & $\begin{array}{l}\text { Responsibility for the work of others (e.g., their morale, division } \\
\text { of labor) (Hurrell \& McLaney, 1988) }\end{array}$ \\
\hline $\begin{array}{l}\text { Lack of social support } \\
\text { from colleagues }\end{array}$ & $\begin{array}{l}\text { Lack of help and support from colleagues (Pejtersen, Kristensen, } \\
\text { Borg, \& Bjorner, 2010) }\end{array}$ \\
\hline $\begin{array}{l}\text { Lack of social support } \\
\text { from supervisors }\end{array}$ & Lack of help and support from supervisors (Pejtersen et al., 2010) \\
\hline $\begin{array}{l}\text { Interpersonal conflict } \\
\text { among colleagues or peers }\end{array}$ & $\begin{array}{l}\text { Negatively charged interactions in the work environment } \\
\text { (Spector \& Jex, 1998) among colleagues or peers }\end{array}$ \\
\hline $\begin{array}{l}\text { Interpersonal conflict } \\
\text { involving one's supervisor }\end{array}$ & $\begin{array}{l}\text { Negatively charged interactions in the work environment } \\
\text { (Spector \& Jex, 1998) involving one's supervisor }\end{array}$ \\
\hline Bureaucratic constraints & $\begin{array}{l}\text { Bureaucracy (e.g., rules, procedures) that prevent individuals } \\
\text { from performing up to their capabilities; (refers to a subset of } \\
\text { Spector \& Jex's (1998) "Organizational Constraints Scale") }\end{array}$ \\
\hline $\begin{array}{l}\text { Material and } \\
\text { technological constraints }\end{array}$ & $\begin{array}{l}\text { Missing or lack of equipment at work that prevent individuals } \\
\text { from performing up to their capabilities; (refers to a subset of } \\
\text { Spector \& Jex's (1998) Organizational Constraints Scale) }\end{array}$ \\
\hline Job insecurity & $\begin{array}{l}\text { Uncertainty about the security of one's job in the future } \\
\text { (Greenhalgh, 1982; Hartley, Jacobson, Klandermans, \& Van } \\
\text { Vuuren, 1991) }\end{array}$ \\
\hline
\end{tabular}


Stressor appraisal. Stressor appraisals reflect individual experiences that vary within a person from one day to the next (Ohly \& Fritz, 2010) and can be influenced by stable individual differences (Lazarus \& Folkman, 1984). The scale used in the present study measured three types of primary appraisal tendencies: challenge and hindrance (Searle \& Auton, 2015) and threat (Feldman, Cohen, Hamrick, \& Lepore, 2004). These appraisal tendencies were operationalized in three ways: (1) challenge appraisal refers to the appraisal of a stressor as one that, although potentially stressful, has associated opportunities for personally meaningful gain (Cavanaugh et al., 2000) and may potentially challenge and engage the individual; (2) hindrance appraisal refers to the appraisal of a stressor that tends to restrict or obstruct opportunities for personally meaningful gains or interferes with an individual's work achievement (Cavanaugh et al., 2000); and (3) threat appraisal refers to the appraisal of a stressor that tends to be directly associated with ongoing exposure to the likelihood for personal harm or loss (Tuckey et al., 2015).

Participants' general challenge, hindrance, and threat appraisal tendencies, when confronted with work-related stressors, defined as stimuli in the work environment that require some adaptive response on the part of the individual (Jex \& Britt, 2014), were measured with the items used by Tuckey, Searle, Boyd, Winefield, and Winefield (2015). In previous research (Searle \& Auton, 2015), the challenge and hindrance items in this measure were found to converge with other appraisal measures and related constructs. These scales were developed from descriptions of challenge appraisal (Lazarus \& Folkman, 1984) and frustration (hindrance) appraisal (Lazarus, 1991) and informed by definitions of challenge and hindrance stressors (e.g., Cavanaugh et al., 2000). They measure the growth and achievement aspects of anticipated personal gains (challenge appraisal) and obstacles (hindrance appraisal). 
Four items were used to measure challenge appraisal (e.g., "They will help me to develop my skills"; $\alpha=.84$ ), and four items were used to measure hindrance appraisal (e.g., "They will restrict my capabilities"; $\alpha=.86$ ) (Searle \& Auton, 2015). Similarly, three items were used to measure threat appraisal (e.g., "They will have a negative impact on me"; $\alpha=.85$ ) (Feldman et al., 2004). In the present study, the internal consistencies for challenge appraisal, hindrance appraisal, and threat appraisal were $\alpha=.84, .89$, and .81 , respectively. In previous literature (Tuckey et al., 2015), appraisal scales were framed in relation to an event or situation (and/or a time frame in which events may occur) so that respondents understood what they were appraising and responses were indicated using a five-point Likert scale from $1=$ Strongly disagree to $5=$ Strongly agree. Similarly, in this study participants were presented with the operational definitions for "work environment", defined as "the environment in which you are working for compensation or experience (for example, part-/full-time work, internship, graduate/research/teaching assistantship, clinical hours)" and "stressor", defined as "a situation or event that requires some adaptive response on your part (for example, a difficult coworker, a work interruption, or a new management style)". In the present study, participants were instructed to "assess how encountering 'stressors' in your 'work environment' is likely to affect you" and indicated their responses on a seven-point Likert scale $(1=$ Disagree strongly, $2=$ Disagree moderately, $3=$ Disagree, $4=$ Neutral, $5=$ Agree, $6=$ Agree moderately, $7=$ Agree strongly) to improve the overall sensitivity of this measure.

Stressor appraisal tendencies. As a secondary measure of participants' stressor appraisal tendencies, the 17 common work-related stressors identified in Table 1 were then presented to participants as stimuli to which participants were asked to respond in three separate 
ways, appraising likelihood of appraising each common stressor as a challenge, hindrance, and threat. These three sections were used to assess participants' appraisals of the specific stressors as challenge, hindrance, and threat, respectively. Each section began with a different set of instructions, which consisted of an explanation of appraisal type (either challenge, hindrance, or threat), a clearly-identified check item (Yes/No) to assess participants' comprehension, and a unique prompt. To avoid influencing responses, the words "stressor", "challenge", "hindrance", and "appraisal" were not used in this portion of the survey. Following the unique prompt in each of the three sections, the 17 work-related stressors were listed consecutively as single-item statements (e.g., "Having discretion in planning out my work and determining my work procedures").

These three sections were used to measure the extent to which an individual appraised an individual stressor as a challenge, a hindrance, and a threat, respectively. For each section participants indicated their response using a slider scale from 0 to $100(0=$ "Not at all" and $100=$ "Completely") and were prompted with a question relating to that specific type of appraisal. The prompt for challenge appraisal tendencies was: "To what extent would the following situations in your work environment provide personal opportunities for you to learn, grow, or achieve?", the prompt for hindrance appraisal tendencies was: "To what extent would the following situations in your work environment restrict or obstruct personal opportunities to learn, grow, or achieve?", and the prompt for hindrance appraisal tendencies was: "To what extent would the following situations in your work environment pose a threat to you?".

Demographics. The following demographic information was gathered to fully understand and report on the sample: sex, age, marital status, ethnicity, race, education level, 
number of children, number of dependents, social support, hours spent working per week, number of individuals supervised, tenure in current position, and years of full-time work. Social support was measured with the question: "If you have problems or are sad, is there anyone you can talk to?" Six alternatives were provided, from which participants could choose all that applied: spouse, children, relative, close friend, neighbor, coworker. An index ranging from zero to six was constructed for an individual's total social support score, which was the number of options chosen from the six possible alternatives (Holmberg, Thelin, \& Stiernström, 2004). 


\section{CHAPTER III}

\section{RESULTS}

Prior to testing the hypotheses, the data were prepared for the analyses as follows. Participants who were not eligible to participate (i.e., did not meet inclusion criteria), who did not complete at least $50 \%$ of the survey, and/or who did not provide most of the demographic information needed for their inclusion as covariates were excluded from the dataset. Additionally, 28 participants who were missing 20 or more responses to the items measuring stressor appraisal tendencies were excluded, because a complete analysis of these individuals' tendencies to appraise stressors as challenges, hindrances, and threats could not be completed.

The following analyses were conducted with data collected from the remaining participants $(N=591)$. Descriptive statistics for and intercorrelations between all study variables are summarized in Tables 2 and 3, respectively. From these simple bivariate analyses, Sense of Coherence (SoC) was found to be significantly correlated with age $(r=.25)$, education level, $(r=$ $.09)$, number of children $(r=.17)$, number of individuals supervised $(r=.11)$, years in current

position $(r=.13)$, years working full-time $(r=.25)$, the number of individuals one felt they could count on for support $(r=.69)$, and all six types of social support: spouse $(r=.15)$, children $(r=$ $.20)$, relative $(r=.18)$, close friend $(r=.15)$, neighbor $(r=.20)$, coworker $(r=.28)$. 
Table 2 Descriptive Statistics for all Study Variables

\begin{tabular}{|c|c|c|c|c|c|c|}
\hline & $N$ & $M$ & Median & $S D$ & Minimum & Maximum \\
\hline Sex & 590 & 1.68 & 2 & 0.47 & 1 & 2 \\
\hline Age & 590 & 36.31 & 31 & 13.26 & 19 & 77 \\
\hline Marital Status & 590 & 1.93 & 2 & 1.03 & 1 & 5 \\
\hline Ethnicity & 591 & 1.97 & 2 & 0.17 & 1 & 2 \\
\hline Race & 591 & 1.29 & 1 & 1.13 & 1 & 7 \\
\hline Education Level & 591 & 5.91 & 6 & 1.39 & 1 & 8 \\
\hline Number of Children & 585 & 0.84 & 0 & 1.34 & 0 & 12 \\
\hline Number of Dependents & 585 & 0.76 & 0 & 1.85 & 0 & 34 \\
\hline Average Weekly Work Hours & 587 & 44.29 & 45 & 11.65 & 0 & 90 \\
\hline Number of Individuals Supervised & 585 & 9.77 & 0 & 69.23 & 0 & 1200 \\
\hline Years in Current Position & 586 & 5.66 & 3 & 7.54 & 0 & 50 \\
\hline Years Working Full-Time & 585 & 13.58 & 9 & 12.93 & 0 & 50 \\
\hline Social Support: Spouse & 591 & 0.53 & 1 & 0.50 & 0 & 1 \\
\hline Social Support: Children & 591 & 0.13 & 0 & 0.34 & 0 & 1 \\
\hline Social Support: Relative & 591 & 0.71 & 1 & 0.46 & 0 & 1 \\
\hline Social Support: Close Friend & 591 & 0.84 & 1 & 0.36 & 0 & 1 \\
\hline Social Support: Neighbor & 591 & 0.10 & 0 & 0.30 & 0 & 1 \\
\hline Social Support: Coworker & 591 & 0.50 & 1 & 0.50 & 0 & 1 \\
\hline Social Support Total & 591 & 2.81 & 3 & 1.24 & 0 & 6 \\
\hline Challenge appraisal & 591 & 21.66 & 22 & 4.40 & 4 & 28 \\
\hline Hindrance appraisal & 591 & 12.09 & 12 & 5.44 & 4 & 28 \\
\hline Threat appraisal & 591 & 10.20 & 10 & 3.89 & 3 & 21 \\
\hline
\end{tabular}

Note: Sex $(1=$ Male, $2=$ Female $)$ 
Table 3 Intercorrelations between all Study Variables

\begin{tabular}{|c|c|c|c|c|c|c|c|c|c|c|c|c|}
\hline Variables & 1. & 2. & 3. & 4. & 5. & 6. & 7. & 8. & 9. & 10. & 11. & 12. \\
\hline \multicolumn{13}{|l|}{ 1. Sex } \\
\hline 2. Age & .01 & & & & & & & & & & & \\
\hline 3. Education Level & .04 & .03 & & & & & & & & & & \\
\hline 4. Number of Children & .02 & $.59 * *$ & -.08 & & & & & & & & & \\
\hline 5. Numner of Dependents & -.01 & $.18 * *$ & -.08 & $.33 * *$ & & & & & & & & \\
\hline 6. Average Weekly Work Hours & -.02 & $.19 * *$ & .06 & $.13 * *$ & .05 & & & & & & & \\
\hline 7. Number of Individuals Supervised & -.05 & $.13 * *$ & .03 & $.14 * *$ & .02 & .07 & & & & & & \\
\hline 8. Years in Current Position & -.05 & $.62 * *$ & .00 & $.37 * *$ & $.16 * *$ & $.11 *$ & $.12 * *$ & & & & & \\
\hline 9. Years Working Full-Time & -.02 & $.94 * *$ & .00 & $.54 * *$ & $.20 * *$ & $.23 * *$ & $.14 * *$ & $.58 * *$ & & & & \\
\hline 10. Social Support: Spouse & -.02 & $.25 * *$ & .05 & $.33 * *$ & $.14 * *$ & $.09 *$ & $.09 *$ & $.17 * *$ & $.26 * *$ & & & \\
\hline 11. Social Support: Children & .06 & $.48 * *$ & -.02 & $.47 * *$ & $.11 * *$ & $.10 *$ & $.19 * *$ & $.23 * *$ & $.44 * *$ & $.17 * *$ & & \\
\hline 12. Social Support: Relative & .07 & $-.28 * *$ & .04 & $-.19 * *$ & -.04 & -.06 & .03 & $-.17 * *$ & $-.26 * *$ & -.02 & -.01 & \\
\hline 13. Social Support: Close Friend & $.17 * *$ & $-.17 * *$ & .03 & $-.13 * *$ & $-.12 * *$ & -.03 & .01 & $-.16 * *$ & $-.16 * *$ & $-.20 * *$ & -.01 & $.20 * *$ \\
\hline 14. Social Support: Neighbor & -.03 & $.09 *$ & .02 & .07 & .02 & .05 & .07 & .03 & .06 & .04 & $.13 * *$ & $.13 * *$ \\
\hline 15. Social Support: Coworker & .02 & .02 & $.09 *$ & .05 & -.06 & .07 & .08 & .04 & .04 & .06 & $.13 * *$ & $.27 * *$ \\
\hline 16, Social Support Total & $.09 *$ & $.11 * *$ & .08 & $.19 * *$ & .02 & .07 & $.15 * *$ & .05 & $.11 * *$ & $.42 * *$ & $.42 * *$ & $.56 * *$ \\
\hline 17. Sense of Coherence (SoC) & .00 & $.25 * *$ & $.09 *$ & $.17 * *$ & .04 & .06 & $.11 * *$ & $.13 * *$ & $.25 * *$ & $.15 * *$ & $.20 * *$ & $.18 * *$ \\
\hline 18. SoC: Comprehensibility & -.02 & $.27 * *$ & $.10 *$ & $.16 * *$ & .02 & .03 & $.13 * *$ & $.16 * *$ & $.27 * *$ & $.13 * *$ & $.16 * *$ & $.10 *$ \\
\hline 19. SoC: Manageability & -.03 & $.15 * *$ & .03 & $.13 * *$ & .03 & .05 & $.09 *$ & .07 & $.15 * *$ & $.12 * *$ & $.17 * *$ & $.22 * *$ \\
\hline 20. SoC: Meaningfulness & .07 & $.22 * *$ & $.12 * *$ & $.15 * *$ & .05 & .08 & .07 & $.10 *$ & $.22 * *$ & $.13 * *$ & $.19 * *$ & $.14 * *$ \\
\hline 21. Work-SoC & .01 & $.16 * *$ & .03 & $.13 * *$ & .00 & .03 & .06 & .06 & $.15 * *$ & .08 & $.14 * *$ & $.11 * *$ \\
\hline 22. Stress in General (SIG) & -.05 & -.05 & -.04 & -.07 & -.05 & $-.21 * *$ & $-.09 *$ & $-.12 * *$ & -.07 & -.04 & .02 & .08 \\
\hline 23. Challenge appraisal & .01 & $-.11 *$ & .02 & -.04 & -.07 & -.04 & .02 & $-.11 *$ & $-.09 *$ & .01 & -.02 & $.16 * *$ \\
\hline 24. Hindrance appraisal & .04 & -.04 & -.05 & -.06 & .04 & .03 & -.07 & -.03 & -.05 & $-.10 *$ & -.07 & -.06 \\
\hline 25. Threat appraisal & .03 & $-.08 *$ & -.01 & $-.09 *$ & -.03 & .02 & $-.08 *$ & -.04 & $-.08 *$ & -.06 & -.06 & -.07 \\
\hline Variables & 13. & 14. & 15. & 16. & 17. & 18. & 19. & 20. & 21. & 22. & 23. & 24. \\
\hline 14. Social Support: Neighbor & $.11 * *$ & & & & & & & & & & & \\
\hline 15. Social Support: Coworker & $.28 * *$ & $.22 * *$ & & & & & & & & & & \\
\hline 16, Social Support Total & $.42 * *$ & $.46 * *$ & $.69 * *$ & & & & & & & & & \\
\hline 17. Sense of Coherence (SoC) & $.15 * *$ & $.20 * *$ & $.28 * *$ & $.38 * *$ & & & & & & & & \\
\hline 18. SoC: Comprehensibility & $.09 *$ & $.12 * *$ & $.23 * *$ & $.28 * *$ & $.86 * *$ & & & & & & & \\
\hline 19. SoC: Manageability & $.16 * *$ & $.20 * *$ & $.24 * *$ & $.36 * *$ & $.91 * *$ & $.67 * *$ & & & & & & \\
\hline 20. SoC: Meaningfulness & $.15 * *$ & $.21 * *$ & $.25 * *$ & $.35 * *$ & $.83 * *$ & $.52 * *$ & $.68 * *$ & & & & & \\
\hline 21. Work-SoC & $.10 *$ & $.14 * *$ & $.15 * *$ & $.23 * *$ & $.63 * *$ & $.50 * *$ & $.58 * *$ & $.56 * *$ & & & & \\
\hline 22. Stress in General (SIG) & .07 & .07 & .01 & .06 & $.23 * *$ & $.21 * *$ & $.25 * *$ & $.14 * *$ & $.34 * *$ & & & \\
\hline 23. Challenge appraisal & $.16 * *$ & $.09 *$ & .08 & $.16 * *$ & $.31 * *$ & $.14 * *$ & $.32 * *$ & $.35 * *$ & $.39 * *$ & $.17 * *$ & & \\
\hline 24. Hindrance appraisal & -.02 & -.06 & -.03 & $-.12 * *$ & $-.38 * *$ & $-.24 * *$ & $-.39 * *$ & $-.36 * *$ & $-.41 * *$ & $-.26 * *$ & $-.52 * *$ & \\
\hline 25. Threat appraisal & -.07 & $-.09 *$ & .01 & $-.10 *$ & $-.41 * *$ & $-.29 * *$ & $-.42 * *$ & $-.35 * *$ & $-.40 * *$ & $-.21 * *$ & $-.48 * *$ & $67 * *$ \\
\hline
\end{tabular}

**. Correlation is significant at the 0.01 level (2-tailed).

*. Correlation is significant at the 0.05 level (2-tailed). 


\section{Hypothesis Tests}

Several analytical approaches were used to test the study hypotheses. The first was a straightforward correlational approach and the second was a more advanced method using Exploratory Structural Equation Modeling (ESEM; Howard, Gagné, Morin, \& Forest, 2016; Morin, Arens, \& Marsh, 2015) and alternative regression-based techniques. The primary analytical tests involved participants' reports of their general stressor appraisal tendencies and general and work-specific SoC. The bivariate correlations reported in Table 3 demonstrate that Hypotheses 1 through 3 were clearly supported. In support of Hypothesis 1, 2, and 3, respectively, SoC was significantly positively correlated with tendency to appraise work stressors as challenges $(r=.31)$, SoC was significantly negatively correlated with tendency to appraise work stressors as hindrances $(r=-.38)$, and $\mathrm{SoC}$ was significantly negatively correlated with tendency to appraise work stressors as threats $(r=-.41)$.

For a more comprehensive test of Hypotheses 1 through 3, a deeper assessment of appraisal and SoC relationships was conducted using an ESEM approach and the Mplus statistical software (v7.3; Muthén \& Muthén, 2014). These analyses involved comparing a series of increasingly complex and more fully specified measurement models, ultimately ending with a seven factor model that also included a general factor to account for the likely influence of common method bias on the responses to the items included in the survey for this study. For these estimates, the ESEM method involved fixing the number of rotations to match the expected number of factors, as recommended by Morin et al. (2015), referencing Asparouhov and Muthén (2009) and Browne (2001). This approach makes it possible to conduct a confirmatory factor analysis (CFA), while also examining how items associated with one factor might cross-load onto or affect other factors. 
The ESEM approach was conducted first without the covariates factored into the ESEM analyses and then again including the covariates. The fit statistics for these successive models are summarized in Tables 4 and 5, respectively. This alternative analysis approach was warranted to specify the items that loaded on each factor. The recent development of ESEM by Asparouhov and Muthén (2009) provides an inclusive framework that allows for the combination of CFA, exploratory factor analysis (EFA), and structural equation modeling (SEM) into a single model (Howard et al., 2016). One of the most common uses of ESEM has been to test theoretically established models that have a previously defined number and count of specified latent factors (Marsh, Morin, Parker, \& Kaur, 2014). More specifically, in ESEM it is possible to test the loadings of indicators on their expected factors and on other factors that are also being tested as part of the overall model. In other words, there is the possibility to combine both confirmatory and exploratory analyses of items and their factor loadings. In the present study, the ESEM approach with targeted oblique rotation made it possible to more comprehensively test the specified hypotheses, while also testing for the presence of a common or shared factor. A conceptual diagram of this approach is represented by the structural models in Figures 2 and 3. 


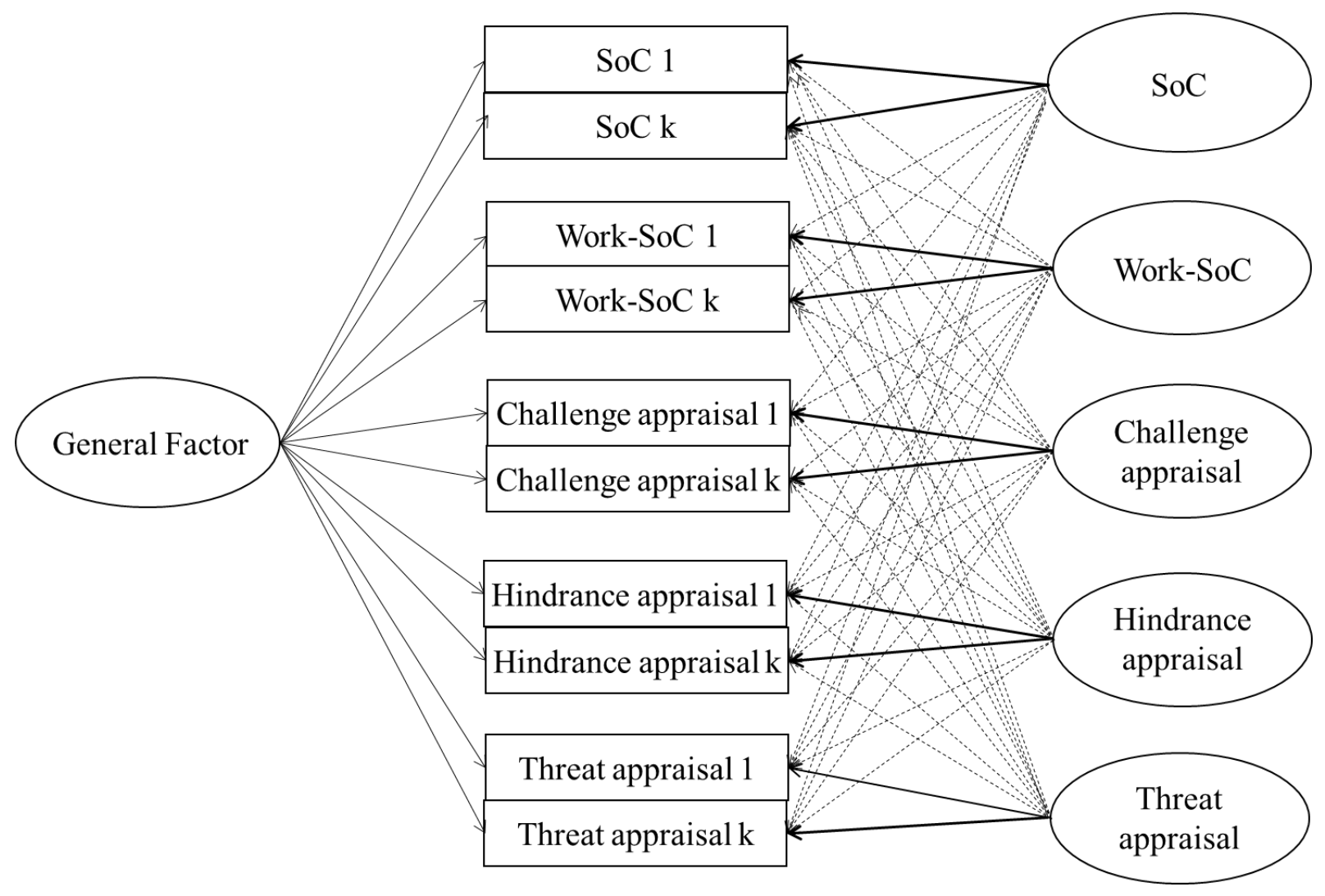

Figure 2 Conceptual Model of ESEM Analysis of Factor Correlations for Five Factor + General Factor Model (2c).

Note: For each observed variable (squares), the items 1-k denote all the items for a given scale; the actual number of items in each scale are noted in the Methodology section. Ovals represent latent factors and rectangles represent observed variables (measured with the relevant scales). Full unidirectional arrows linking ovals and rectangles represent the item uniqueness. Dotted unidirectional arrows linking ovals and rectangles represent the cross-loadings. (With ESEM, all items are permitted to load on all factors. 


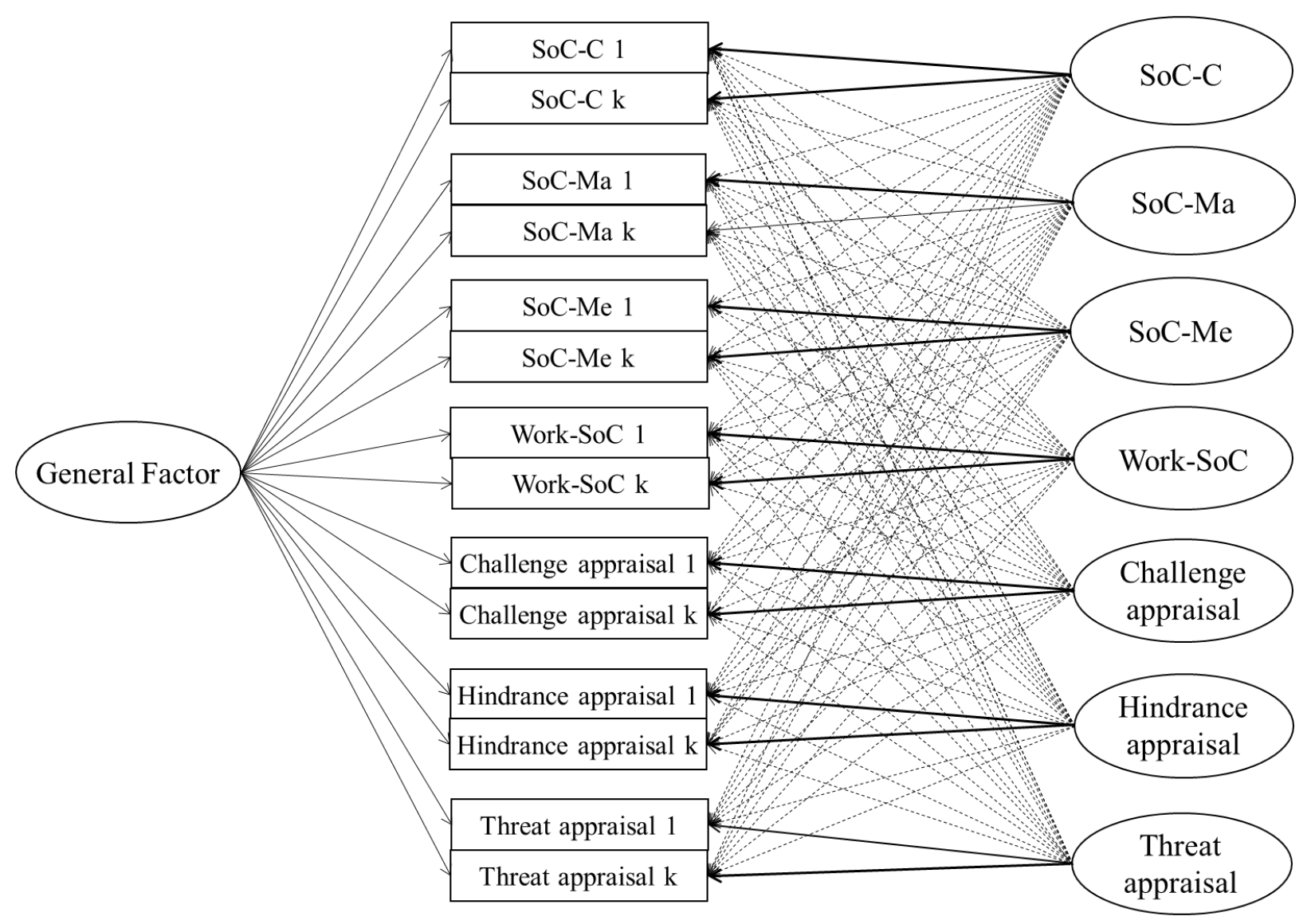

Figure 3 Conceptual Model of ESEM Analysis of Factor Correlations for Seven Factor + General Factor Model (2e)

Note: For each observed variable (squares), the items 1-k denote all the items for a given scale; the actual number of items in each scale are noted in the Methodology section. Ovals represent latent factors and rectangles represent observed variables (measured with the relevant scales). Full unidirectional arrows linking ovals and rectangles represent the item uniqueness. Dotted unidirectional arrows linking ovals and rectangles represent the cross-loadings. (With ESEM, all items are permitted to load on all factors.) 
Table 4 Measurement Model of Fit Statistics without Covariates

\begin{tabular}{|c|c|c|c|c|c|c|c|c|c|}
\hline Model & $\chi^{2}$ & $d f$ & AIC & BIC & RMSEA & $90 \% \mathrm{CI}$ & CFI & TLI & SRMR \\
\hline 1a. Single factor model & $6131.79 * *$ & 1127 & 96978.62 & 97622.75 & $0.09 *$ & $(0.085,0.089)$ & 0.53 & 0.51 & 0.09 \\
\hline 1b. Five factor model & $2454.40 * *$ & 941 & 93005.52 & 94464.66 & 0.05 & $(0.050,0.055)$ & 0.86 & 0.82 & 0.04 \\
\hline 1c. Five factor +1 General Factor model & $1910.52 * *$ & 897 & 92575.91 & 94227.85 & 0.04 & $(0.041,0.046)$ & 0.91 & 0.88 & 0.03 \\
\hline 1d. Seven factor model & $1664.41 * *$ & 854 & 92381.83 & 94222.19 & 0.04 & $(0.037 .0 .043)$ & 0.92 & 0.90 & 0.03 \\
\hline 1e. Seven factor +1 General Factor model & $1542.01 * *$ & 812 & 92274.76 & 94299.15 & 0.04 & $(0.036,0$ & 0.93 & 0.90 & 0.03 \\
\hline \multicolumn{10}{|l|}{$* * p<.001$} \\
\hline \multicolumn{10}{|l|}{$*$ Probability $R M S E A<=.05$} \\
\hline \multirow{4}{*}{\multicolumn{10}{|c|}{$\begin{array}{l}\chi^{2}=\text { Chi square } d f=\text { degrees of freedom; AIC = Akaike Information Criterion; } \mathrm{BIC}=\text { Bayesian } \\
\text { Information Criterion; RMSEA = Root Mean Square Error of Approximation; CI = Confidence } \\
\text { Interval; CFI = Comparative Fit Index; TLI = Tucker-Lewis Index; SRMR = Standardized Root } \\
\text { Mean Square Residual }\end{array}$}} \\
\hline & & & & & & & & & \\
\hline & & & & & & & & & \\
\hline & & & & & & & & & \\
\hline \multicolumn{10}{|c|}{$\begin{array}{l}\text { Note: Covariates not factored into analysis were sex, marital status, race, ethnicity, number of } \\
\text { children, number of dependents, social support, tenure in current position, number of years } \\
\text { working full-time, and highest level of education }\end{array}$} \\
\hline
\end{tabular}

Table 5 Measurement Model of Fit Statistics with Covariates

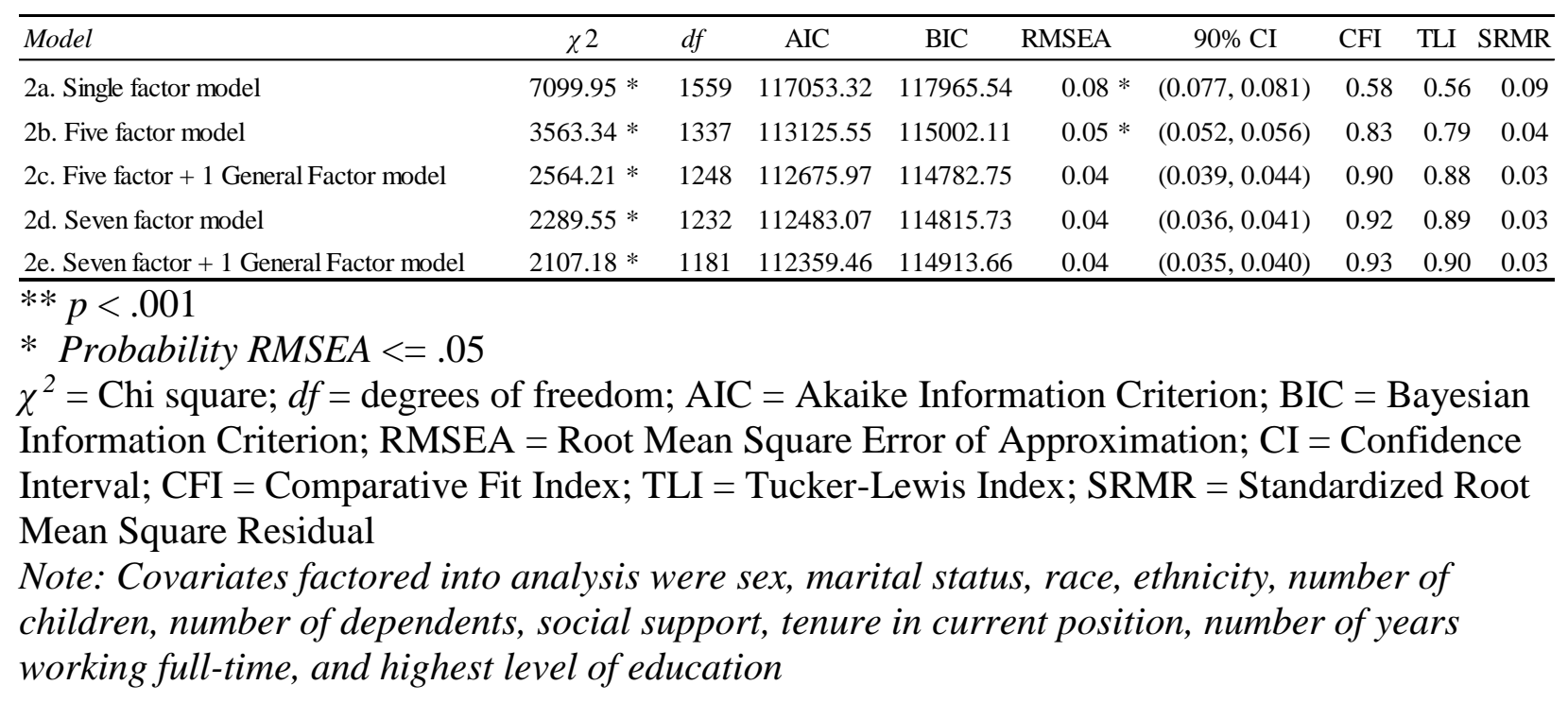

Based on the model comparisons summarized in Tables 6 and 7, the factor correlations from the models including covariates are displayed for the five factor model ( $2 b)$ and five factor with one general factor model (2c) and for the seven factor model (2d) and seven factor with general factor model (2e). It is important to note that the ESEM results of Hypotheses 1 through 
3 displayed in Table 6 differed from the bivariate correlation results of Hypotheses 1 through 3 displayed in Table 3. In the ESEM analyses, the five factor models included the three types of stressor appraisal tendencies (challenge, hindrance, and threat), Work-SoC, and $\mathrm{SoC}$ (total), and the seven factor models included the three stressor appraisal tendencies, Work-SoC, and the three SoC subdimension measures: comprehensibility (SoC-C), manageability (SoC-Ma), and meaningfulness (SoC-Me).

Specifically, Model $2 \mathrm{~b}$ showed a significant correlation in the hypothesized direction between SoC and hindrance appraisal tendency but not for challenge or threat appraisal tendencies. Model 2c, which included a general factor, did not show significant correlations between SoC and any of the stressor appraisal tendencies. It did show a significant negative correlation between Work-SoC and hindrance appraisal tendency. Model $2 \mathrm{~d}$ showed significant positive correlations between challenge appraisal tendency and the three subdimensions of SoC and with Work-SoC. There were significant negative correlations between hindrance appraisal tendency and SoC-C and SoC-Me as well as Work-SoC. There was an unexpected positive relationship between threat appraisal tendency and SoC-Ma. Model 2d, which included a general factor, showed two additional surprising results: a significant negative relationship between challenge appraisal tendency and SoC-C and a significant positive relationship between hindrance appraisal tendency and SoC-Ma. Model 2d showed significant negative relationships between threat appraisal tendency and the subdimensions SoC-C and SoC-Me, but there were no significant relationships between any of the three appraisal tendencies and Work-SoC. 
Table 6 Factor Correlations for Five Factor (2b) and Five Factor + General Factor (2c) Models

\begin{tabular}{lcc|cc} 
& \multicolumn{2}{c|}{ Model 2b } & \multicolumn{2}{c}{ Model 2c } \\
\hline & SoC & Work-SoC & SoC & Work-SoC \\
\hline Challenge & .302 & .280 & -.093 & .091 \\
Hindrance & $\mathbf{- . 3 6 9}$ & -.283 & -.050 & $\mathbf{- . 1 3 9}$ \\
Threat & .172 & .035 & .036 & -.035 \\
\hline
\end{tabular}

Note: Covariates included sex, marital status, race, ethnicity, number of children, number of dependents, social support, tenure in current position, number of years working full-time, and highest level of education.

Table 7 Factor Correlations for Seven Factor (2d) and Seven Factor + General Factor (2e) Models

Model 2d

Model 2e

\begin{tabular}{lcccc|cccc}
\hline & SoC-C & SoC-Ma & SoC-Me & Work-SoC & SoC-C & SoC-Ma & SoC-Me & Work-SoC \\
\hline Challenge & $\mathbf{. 1 0 5}$ & $\mathbf{. 1 2 7}$ & $\mathbf{. 2 6 2}$ & $\mathbf{. 3 7 1}$ & $\mathbf{- . 1 9 8}$ & -.056 & .026 & .002 \\
Hindrance & $\mathbf{- . 2 0 9}$ & -.085 & $\mathbf{- . 2 4 2}$ & $\mathbf{- . 3 5 8}$ & .115 & $\mathbf{. 1 1 3}$ & .028 & -.060 \\
Threat & .066 & $\mathbf{. 0 9 1}$ & -.063 & .029 & $\mathbf{- . 1 6 3}$ & -.092 & $\mathbf{- . 1 6 5}$ & -.054 \\
\hline
\end{tabular}

Note: Covariates included sex, marital status, race, ethnicity, number of children, number of dependents, social support, tenure in current position, number of years working full-time, and highest level of education.

Hypothesis 4 tested whether the relationships between SoC and stressor appraisal tendencies (H1-H3) were moderated by age, such that they were stronger for older individuals than for younger individuals. To test this hypothesis, a three-stage hierarchical multiple regression analysis was conducted for each of the three stressor appraisal tendencies. In step one, the standardized values (i.e., $z$-scores) for the demographic covariates of sex, education level, number of children, number of dependents, average weekly work hours, tenure in current position, tenure working full-time, and social support total were entered, given previously observed relationships between these variables and other study variables of interest. In step two, the standardized values for age and SoC were entered to test the interaction of these two variables. In step three, the product of the standardized age and SoC values was entered. Results 
indicated that the interaction term did not significantly contribute to the variance explained by these regression models and, therefore, failed to support Hypothesis 4. Results of this analysis are presented in Table 8. Table 9 shows the effects of age on the relationship between Work-SoC and stressor appraisal tendencies. A three-stage hierarchical multiple regression analysis was conducted in the same manner as for SoC, but in step three, the product of age and Work-SoC was entered to test the interaction of these two variables. Results indicated that the interaction term did not significantly contribute to the regression model.

The information summarized in Table 8 and Table 9 does not support Hypothesis 4. However, the results summarized in Table 9 reveal that age did significantly predict challenge appraisal, as shown by the main effects. Additionally, Table 8 shows main effects of SoC on stressor appraisal, suggesting that $\mathrm{SoC}$ was a significant predictor of challenge, hindrance, and threat appraisal tendencies. Table 9 shows the main effects of Work-SoC on stressor appraisal, suggesting that Work-SoC was a significant predictor of challenge and hindrance appraisal.

Table 8 Challenge, Hindrance, and Threat Appraisals Explained by Age and Sense of Coherence

\begin{tabular}{|c|c|c|c|c|c|c|c|c|c|}
\hline & \multicolumn{3}{|c|}{ Challenge Appraisal } & \multicolumn{3}{|c|}{ Hindrance Appraisal } & \multicolumn{3}{|c|}{ Threat Appraisal } \\
\hline & & Beta & & & Beta & & & Beta & \\
\hline Predictors & Step 1 & Step 2 & Step 3 & Step 1 & Step 2 & Step 3 & Step 1 & Step 2 & Step 3 \\
\hline Sex & -0.01 & 0.00 & 0.00 & 0.05 & 0.04 & 0.04 & 0.04 & 0.03 & 0.03 \\
\hline Average Weekly Work Hours & -0.03 & -0.03 & -0.02 & 0.05 & 0.05 & 0.05 & 0.05 & 0.04 & 0.04 \\
\hline Years in Current Position & -0.08 & -0.05 & -0.05 & 0.00 & -0.02 & -0.02 & 0.01 & 0.00 & 0.00 \\
\hline Years Working Full-Time & -0.06 & 0.06 & 0.07 & -0.04 & -0.06 & -0.06 & -0.09 & -0.03 & -0.03 \\
\hline Social Support Total & $0.17 *$ & 0.05 & 0.05 & $-0.12 *$ & 0.02 & 0.02 & $-0.10 *$ & 0.05 & 0.06 \\
\hline Sense of Coherence (SoC) & & $0.33 *$ & $0.33 *$ & & $-0.40 *$ & $-0.39 *$ & & $-0.43 *$ & $-0.43 *$ \\
\hline Age & & -0.22 & -0.23 & & 0.11 & 0.13 & & 0.04 & 0.06 \\
\hline Age $x$ SoC & & & 0.04 & & & -0.04 & & & -0.07 \\
\hline$\Delta R^{2}$ & 0.03 & 0.12 & 0.12 & 0.02 & 0.13 & 0.00 & 0.02 & 0.15 & 0.00 \\
\hline$\Delta F$ & $4.81 *$ & $30.90 *$ & 1.18 & $2.33 *$ & $42.90 *$ & 0.86 & $2.33 *$ & $52.16 *$ & 2.99 \\
\hline Adjusted $R^{2}$ & 0.03 & 0.12 & 0.12 & 0.01 & 0.14 & 0.14 & 0.01 & 0.16 & 0.16 \\
\hline$F$ & $4.81 *$ & $12.62 *$ & $11.20 *$ & $2.33 *$ & $14.16 *$ & $12.50 *$ & $2.33 *$ & $16.86 *$ & $15.18 *$ \\
\hline
\end{tabular}

$N=591 ; * p<.05$ 
Table 9 Challenge, Hindrance, and Threat Appraisals Explained by Age and Work-SoC

\begin{tabular}{|c|c|c|c|c|c|c|c|c|c|}
\hline & \multicolumn{3}{|c|}{ Challenge Appraisal } & \multicolumn{3}{|c|}{ Hindrance Appraisal } & \multicolumn{3}{|c|}{ Threat Appraisal } \\
\hline & & Beta & & & Beta & & & Beta & \\
\hline Predictors & Step 1 & Step 2 & Step 3 & Step 1 & Step 2 & Step 3 & Step 1 & Step 2 & Step 3 \\
\hline Sex & -0.01 & 0.00 & 0.00 & 0.05 & 0.04 & 0.04 & 0.04 & 0.04 & 0.04 \\
\hline Average Weekly Work Hours & -0.03 & -0.03 & -0.03 & 0.05 & 0.05 & 0.05 & 0.05 & 0.04 & 0.04 \\
\hline Years in Current Position & -0.08 & -0.04 & -0.04 & 0.00 & -0.03 & -0.03 & 0.01 & -0.01 & -0.01 \\
\hline Years Working Full-Time & -0.06 & 0.10 & 0.11 & -0.04 & -0.10 & -0.10 & -0.09 & -0.07 & -0.08 \\
\hline Social Support Total & $0.17 *$ & $0.08 *$ & 0.08 & $-0.12 *$ & -0.03 & -0.03 & -0.10 & -0.02 & -0.01 \\
\hline Work-SoC & & $0.40 *$ & $0.39 *$ & & $-0.40 *$ & $-0.40 *$ & & -0.39 & -0.39 \\
\hline Age & & $-0.24 *$ & $-0.27 *$ & & 0.13 & 0.13 & & 0.04 & 0.06 \\
\hline Age x Work-SoC & & & 0.06 & & & 0.00 & & & -0.04 \\
\hline$\Delta R^{2}$ & 0.04 & 0.15 & 0.01 & 0.02 & 0.15 & 0.00 & 0.02 & 0.14 & 0.00 \\
\hline$\Delta F$ & $4.81 *$ & $52.90 *$ & 3.33 & $2.33 *$ & $52.65 *$ & 0.01 & $2.33 *$ & $48.89 *$ & 1.17 \\
\hline Adjusted $R^{2}$ & 0.03 & 0.18 & 0.18 & 0.01 & 0.16 & 0.16 & 0.01 & 0.15 & 0.15 \\
\hline$F$ & $4.81 *$ & $19.17 *$ & $17.26 *$ & $2.33 *$ & $17.00 *$ & $14.85 *$ & $2.33 *$ & $15.91 *$ & $14.07 *$ \\
\hline
\end{tabular}

$N=591 ; * p<.05$ 


\section{CHAPTER IV DISCUSSION AND CONCLUSION}

Individual differences shape cognitive perceptions and influence the complex stressor appraisal process (Lazarus \& Folkman, 1984). According to the theory of salutogenesis, which focuses on the origin of health instead of the origin of disease (i.e., pathogenesis), SoC is an emotional-cognitive resource that influences an individual's perceptions of stimuli in the environment and is central to explaining an individual's progress towards health and well-being over the course of life (Antonovsky, 1979, 1987b). Individuals with a stronger SoC perceive their environment as more comprehensible, manageable, and meaningful and are better able to cope with stressors in a healthy way (Antonovsky, 1987b). The present study expands the understanding of factors that impact the way in which individuals appraise stressors in their work environment. It was designed to assess the role of the generalized emotional-cognitive individual difference, SoC, in the appraisal of work-related stressors as challenges, hindrances, and threats (H1-H3) and to examine the moderating effect of age on the relationship between individuals' SoC and their appraisal of common work-related stressors (H4).

Hypotheses 1 through 3 were tested using both a correlational approach and Exploratory Structural Equation Modeling (ESEM) and alternative regression-based techniques. The results of the bivariate correlations supported these hypotheses, revealing that $\mathrm{SoC}$ was significantly positively correlated with challenge appraisal tendency and significantly negatively correlated with hindrance and threat appraisal tendencies. There were also significant correlations in the 
same directions between the work-specific measure of SoC (Work-SoC) and challenge, hindrance, and threat appraisal tendencies. These initial results suggest that individuals with a stronger SoC are more likely to appraise stressors as challenges and that individuals with a weaker $\mathrm{SoC}$ are more likely to appraise stressors as hindrances and threats. Similarly, the initial results suggest that individuals with a stronger Work-SoC are more likely to appraise stressors as challenges and individuals with a weaker Work-SoC more likely to appraise stressors as hindrances and threats. Although the two statistical methods used to test Hypotheses 1 through 3 did not yield identical results, the results of the ESEM analyses do suggest that there are some significant relationships between specific subdimensions of SoC (SoC-C, SoC-Ma, and SoC-Me) and the tendency to appraise stressors as challenges, hindrances, and threats.

The results of Model $2 \mathrm{~d}$ reveal several significant relationships after a general factor was added to the model. As shown in Table 7, individuals who viewed their world as more comprehensible appeared to be significantly less likely to appraise stressors in their work environment as challenges and as threats; individuals who viewed their world as more manageable appeared to be significantly more likely to appraise stressors in their work environment as hindrances; and individuals who viewed their world as more meaningful appeared to be significantly less likely to appraise stressors in their work environment as threats. These interesting findings have not previously emerged in research involving the SoC construct and its subdimensions.

Hypothesis 4 was tested using a three-stage hierarchical multiple regression analysis, which added in the standardized values for the included variables. These results indicated that the interaction term did not significantly account for additional variance and therefore failed to support Hypothesis 4. A similar three-stage hierarchical multiple regression analysis was used to 
examine the interaction of age and Work-SoC on stressor appraisal tendencies but did not reveal a significant contribution. It is important to note that $\mathrm{SoC}$ and Work-SoC significantly predicted challenge, hindrance, and threat appraisal and that age played a significant role as a predictor of challenge appraisal in both the analyses involving SoC and Work-SoC.

Although these results indicate that the interactions (age x SoC; age x Work-SoC) did not significantly account for variance, the interaction of age and Work-SoC on challenge appraisal did approach significance $($ Beta $=.06, p=.069)$. Figure 4 summarizes the relationship between challenge appraisal and Work-SoC as moderated by age in the present study. Antonovsky (1984) considered a strong SoC to be a significant factor in the appraisal of unavoidable stimuli as opportunities, and research has shown that SoC increases with age throughout the lifespan (Feldt et al., 2000; Nilsson et al., 2010). Thus, in the present study the hypothesis was that age would have a positive effect on the relationship between individuals' work-specific $\mathrm{SoC}$ and the tendency to appraise stressors as challenges. Figure 4 demonstrates that as individuals in the sample get older they are more likely to appraise stressors as challenges, which is in line with some of the previous literature. Unexpectedly, however, the results demonstrated in Figure 4 suggest that individuals with a high Work-SoC are less likely to perceive stressors in their environment as challenges than those with a low Work-SoC, across all ages. Additionally, there is a pattern of results associated with age among participants in this study, but further testing is needed to determine this relationship. 


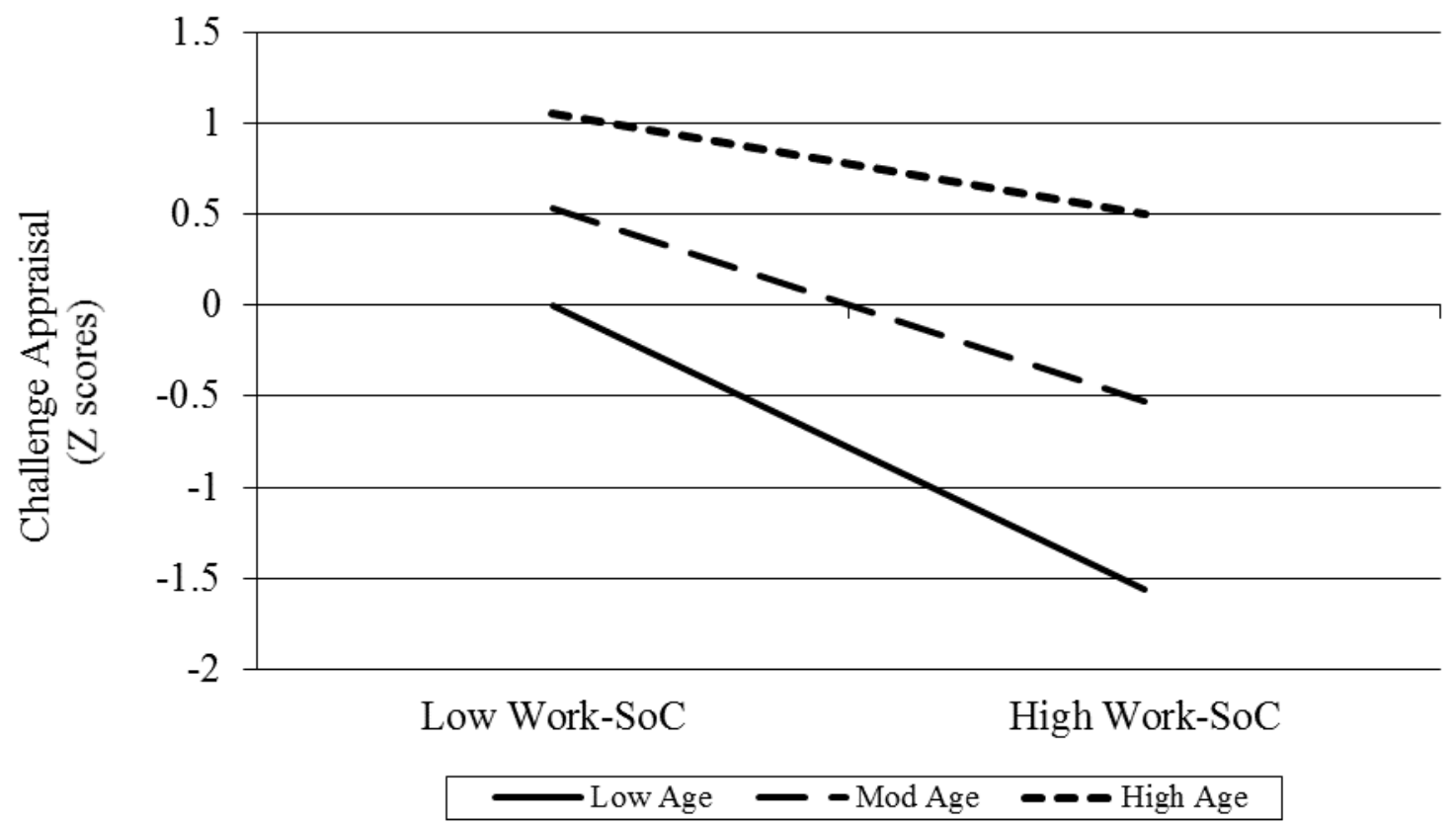

Figure 4 Relationship between Challenge Appraisal and Work-SoC Moderated by Age

\section{Limitations and Future Research}

One limitation with the present study concerns the study design. Although attention check items and other instructional attempts were made to guide participants to think in terms of their "work environment", the use of a single self-report questionnaire may have contributed to common method bias in the sample. Future research on this topic should examine the role of SoC in stressor appraisal tendencies by using a variety of methods and multiple testing periods.

Research should also investigate the psychometric properties of the SoC and Work-SoC measures. This is particularly evident, given the very different results pertaining to Hypotheses 1 through 3 between the two analytical methods employed in this study.

Another limitation in this study may be the generalizability of the findings to populations that differ from the one represented by the present sample, a summary of which is provided in 
Table 2. Within the sample, there appeared to be a bias in the stressor appraisal tendencies of individuals within the sample, which may have resulted in a restriction of range. In other words, the sample as a whole was more likely to appraise stressors as challenges than as hindrances or threats, and this may have contributed to a low range restriction for threat appraisal. Future research in this area should broaden the sampling strategy and consider targeting populations that might be more likely to appraise stressors as threats, which might allow for greater generalizability of the results.

\section{Implications}

The present study increased our understanding of the role of the cognitive individual difference, SoC, in the stressor appraisal process. It was unique in that it examined the role that SoC plays in an individual's appraisal of stressors as challenges, hindrances, and threats. The literature in this area suggests a positive relationship between SoC and challenge stressor appraisal and a negative relationship between $\mathrm{SoC}$ and hindrance and threat appraisals (Antonovsky, 1987a). While the initial analyses in the present study further confirmed this, a newer and more sophisticated statistical approach did not. The non-significant relationships between SoC and stressor appraisal tendencies indicate that in the large body of research around SoC, which has not previously involved more advanced analytical techniques, the identification of another factor, unrelated to individual cognitive differences and more related to the methodology, may have been overlooked. Including a general factor in the model that treated SoC as a single construct did not show the expected results, but including a general factor in the model that separated SoC into its three subdimensions surprisingly revealed significant results between these subdimensions and specific stressor appraisal tendencies. 
Although Model 2c provides the clearest test of Hypotheses 1 through 3, Model 2e was used to examine the subdimensions of SoC. The ESEM results revealed unexpected significant relationships between each of the stressor appraisal tendencies and the SoC subdimensions of comprehensibility (SoC-C), manageability (SoC-Ma), and meaningfulness (SoC-Me). According to (Antonovsky, 1987a), individuals who score high in the SoC-C dimension perceive events in their lives to be consistent, clear, and known, as opposed to unpredictable or confusing. Individuals who score high on the challenge appraisal items perceive work-related stressors as helping them to learn, develop, and do well, whereas individuals who score high on the threat appraisal items perceive work-related stressors as resulting in negative outcomes and negative personal experiences. The results of the present study show that individuals who scored higher on the SoC-C subdimension were significantly less likely to appraise stressors in their work environment as either challenges or threats. These unanticipated results may suggest that individuals who feel that their lives are consistent and predictable are less likely to perceive that stressors in their work environment will help them grow and develop and are also less likely to perceive that stressors in their work environment will cause them personal harm. However, these results may also suggest that individuals who feel that their lives are consistent and predictable are less likely to perceive stressors in their work environment as inconsistent or unpredictable and, therefore, are less likely to perceive stressors in their work environment as something that might have an impact on them at all, whether that be a positive impact (challenge) or a negative impact (threat). Further research is needed to better understand the mechanisms through which SoC-C operates, and these seemingly contradictory stressor appraisal results may provide some insight. 
A relationship was also found between the manageability dimension of SoC and hindrance appraisal tendency. According to (Antonovsky, 1987a), individuals who score high in the SoC-Ma subdimension perceive that their capacity to deal with events in their lives leads to fair, resolvable, and controllable situations. Tuckey et al. (2015) stated that individuals who score high on the hindrance appraisal items perceive that stressors in their work environment could obstruct or restrict their capabilities and achievements, and they suggested that this type of appraisal occurs when the pursuit of a goal is blocked and frustration arises. The results of the present study show that individuals who scored higher in the SoC-Ma subdimension were more likely to appraise stressors in their work environment as hindrances. This suggests that individuals who feel that they can rely on themselves or others to manage and control events in their environment may be more likely to appraise work-related stressors as frustrations than as providing opportunities for personal harm or personal gain. One possible explanation for this puzzling result is that while these individuals perceive stressors as obstacles that block their goals and cause frustration, they may still feel that they have the resources needed to manage these stressors. A possible intervention for individuals high in SoC-Ma may involve the reduction of obstacles and other items in their work environment that contribute to frustration, but future research is needed to investigate this.

Antonovsky (1987a) suggested that individuals who score high in the SoC-Me subdimension perceive events in their lives as interesting, meaningful, and satisfying. Individuals who score high on the threat appraisal items perceive that stressors in their work environment will result in negative outcomes, such as personal loss or harm. The results of the present study show that individuals who scored higher in the SoC-Me subdimension were less likely to appraise stressors in their work environment as threats. These results suggest that individuals 
who feel that their lives are fascinating, purposeful, and pleasurable are less likely to appraise work-related stressors as having a negative impact and causing negative experiences for them. This is in line with the SoC theory itself and may have important implications within the workplace. Further research should examine the possibility that an individual's tendency towards threat appraisal might be impacted by an underlying emotional cognitive mechanism that relates to one's view of the world as meaningful.

While the results of Hypothesis 4 indicated that age did not moderate the relationship between SoC and an individual's tendency to appraise stressors as challenges, hindrances, or threats, age did have a main effect on challenge appraisal. This suggests that, as individuals age, they are more likely to perceive stressors in their work environment as providing opportunities to learn and develop, which is in line with previous research. However, these results also indicate that individuals who perceive their work environment as incoherent are more likely to appraise work-related stressors as challenges than individuals who perceive their work environment as coherent. This finding is contrary to the literature in this area, and future research is needed to further understand this relationship. The advanced statistical analyses used in this study allowed for the identification of a general method factor common to all measured items, which calls into question the psychometric properties of the measure used in the study. Future research on SoC using an ESEM approach is needed to investigate this possibility. Another area for future research could be based on evaluating how these results might differ in a more diverse sample.

\section{Conclusion}

The present study was designed to examine the role of $\mathrm{SoC}$ on an individual's perception of stressors in their work environment as having potential for allowing personal gain (challenges) 
than for obstructing personal gain (hindrance) or causing personal harm (threat), and to examine age as a moderator of these relationships. While a large body of literature on SoC supports the hypothesized relationships in this study, these results indicate that SoC may play a different role in an individual's perception of their environment than has been previously demonstrated. The results also indicate that age may not contribute to an individual's SoC, despite prior research that suggests otherwise. Researchers should further investigate the effects of age on an individual's perception of their work environment before using age as an indicator of stressor appraisal.

Prior to this study, research had not demonstrated the individual relationships between each of the subdimensions of SoC and the three types of stressor appraisal. Thus, it is important to highlight that the general SoC measure may not be as useful as the SoC subdimension scales for determining how an individual appraises stressors in their work environment. Researchers should aim to understand the mechanisms through which the subdimensions of SoC operate and should further investigate how individuals' perceptions of their work environment as manageable, comprehensible, or meaningful may independently impact their appraisal of workrelated stressors. This information could prove valuable in future interventions aimed at impacting how individuals appraise stressors in their work environment. 


\section{REFERENCES}

Alm, S. (2001). The resurgence of mass unemployment. Stockholm: Swedish Institute for Social Research.

Amirkhan, J. H., \& Greaves, H. (2003). Sense of coherence and stress: The mechanics of a healthy disposition. Psychology \& Health, 18(1), 31-62. doi:10.1080/0887044021000044233

Antonovsky, A. (1979). Health, stress, and coping: New perspectives on mental and physical well-being. San Francisco: Jossey-Bass.

Antonovsky, A. (1984). The sense of coherence as a determinant of health. . In M. J.D. \& M. N. (Eds.), Behavioral health: A handbook of health enhancement and disease prevention (pp. 194-202). New York: Wiley.

Antonovsky, A. (1985). The life cycle, mental health, and the sense of coherence. The Israel journal of psychiatry and related sciences, 22(4), 273-280.

Antonovsky, A. (1987a). Health promoting factors at work: The sense of coherence. In R. Kalimo, M. A. El-Batawi, \& C. L. Cooper (Eds.), Psychosocial factors at work and their relation to health (pp. 153-167). Geneva, Switzerland: World Health Organization.

Antonovsky, A. (1987b). Unraveling the mystery of health: How people manage stress and stay well. San Francisco: Jossey-Bass. 
Antonovsky, A. (1991). The structural sources of salutogenic strengths. In C. L. Cooper \& R. Payne (Eds.), Personality and stress: Individual differences in the stress process. Oxford, UK: Sons.

Antonovsky, A. (1993). The structure and properties of the sense of coherence scale. Social Science \& Medicine, 36(6), 725-733. doi:10.1016/0277-9536(93)90033-z

Antonovsky, A., \& Sourani, T. (1988). Family sense of coherence and family adaptation. Journal of Marriage and the Family, 50(1), 79-92. doi:10.2307/352429

Apers, S., Luyckx, K., Rassart, J., Goossens, E., Budts, W., \& Moons, P. (2013). Sense of coherence is a predictor of perceived health in adolescents with congenital heart disease: A cross-lagged prospective study. International Journal of Nursing Studies, 50(6), 776785. doi:10.1016/j.ijnurstu.2012.07.002

Artinian, B. M. (1997). Situational sense of coherence: Development and measurement of the construct. In B. M. Artinian \& M. M. Conger (Eds.), The intersystem model: Integrating theory and practice (pp. 18-30). Thousand Oaks, CA: Sage.

Asparouhov, T., \& Muthén, B. (2009). Exploratory structural equation modeling. Structural Equation Modeling, 16, 397-438.

Baker, M., North, D., \& Smith, D. F. (1997). Burnout, sense of coherence and sources of salutogenesis in social workers. Psychology, 34(1), 22-26.

Bakker, A. B., \& Sanz-Vergel, A. I. (2013). Weekly work engagement and flourishing: The role of hindrance and challenge job demands. Journal of Vocational Behavior, 83(3), 397409. doi:http://dx.doi.org/10.1016/j.jvb.2013.06.008

Barnard, A., Peters, D., \& Muller, H. (2010). Financial health and sense of coherence. Journal of Human Resource Management, 8(1), 1-12. 
Basinska, M. A., Andruszkiewicz, A., \& Grabowska, M. (2011). Nurses' sense of coherence and their work related patterns of behaviour. International Journal of Occupational Medicine and Environmental Health, 24(3), 256-266. doi:10.2478/S13382-011-0031-1

Bauer, G. F., \& Jenny, G. J. (2007). Development, implementation and dissemination of occupational health management (OHM): Putting salutogenesis into practice. In J. Houdmont \& S. McIntyre (Eds.), Occupational health psychology: European perspectives on research, education and practice (pp. 219-250). Castelo de Maia: ISMAI Publications.

Bauer, G. F., Vogt, K., Inauen, A., \& Jenny, G. J. (2015). Work-SoC: Development and validation of a scale measuring Work-Related Sense of Coherence. Zeitschrift Fur Gesundheitspsychologie, 23(1), 20-30. doi:10.1026/0943-8149/a000132

Beehr, T. A., Glaser, K. M., Canali, K. G., \& Wallwey, D. A. (2001). Back to basics: Reexamination of Demand-Control Theory of occupational stress. Work and Stress, 15(2), 115-130. doi:Doi 10.1080/02678370110067002

Bengtsson-Tops, A., \& Hansson, L. (2001). The validity of Antonovsky's Sense of Coherence measure in a sample of schizophrenic patients living in the community. Journal of Advanced Nursing, 33(4), 432-438. doi:DOI 10.1046/j.1365-2648.2001.01692.x

Benz, T., Angst, F., Lehmann, S., \& Aeschlimann, A. (2013). Association of the sense of coherence with physical and psychosocial health in the rehabilitation of osteoarthritis of the hip and knee: a prospective cohort study. Bmc Musculoskeletal Disorders, 14. doi:Artn 159. 10.1186/1471-2474-14-159 
Binkowska-Bury, M., \& Januszewicz, P. (2010). Sense of coherence and health-related behaviour among university student-A questionnaire survey. Central European journal of public health, 18(3), 145-150.

Bolger, N., \& Zuckerman, A. (1995). A framework for studying personality in the stress process. Journal of Personality and Social Psychology, 69, 890-902.

Boswell, W. R., Olson-Buchanan, J. B., \& LePine, M. A. (2004). Relations between stress and work outcomes: The role of felt challenge, job control, and psychological strain. Journal of Vocational Behavior, 64(1), 165-181. doi:10.1016/S0001-8791(03)00049-6

Bowman, B. J. (1996). Cross-cultural validation of Antonovsky's sense of coherence scale. Journal of Clinical Psychology, 52(5), 547-549. doi:Doi 10.1002/(Sici)10974679(199609)52:5<547::Aid-Jclp8>3.0.Co;2-K

Browne, M. (2001). An overview of analytic rotation in exploratory factor analysis. Multivariate Behavioral Research, 36, 111-150.

Bureau of Labor Statistics [BLS]. (2016, September 12, 2016). Labor force characteristics. Labor force statistics from the current population survey.

Cavanaugh, M. A., Boswell, W. R., Roehling, M. V., \& Boudreau, J. W. (2000). An empirical examination of self-reported stress among U.S. managers. Journal of Applied Psychology, 85, 65-74.

Cederblad, M., \& Hansson, K. (1996). Sense of coherence: A concept influencing health and quality of life in a Swedish psychiatric at-risk group. Israel Journal of Medical Sciences, 32(3-4), 194-199. 
Cohen, M., Ben-Zur, H., \& Rosenfeld, M. J. (2008). Sense of coherence, coping strategies, and test anxiety as predictors of test performance among college students. International Journal of Stress Management, 15(3), 289-303. doi:10.1037/1072-5245.15.3.289

Cooper, C. L., Dewe, P.J., \& O’Driscoll, M.P. (2001). Organizational Stress: A Review and Critique of Theory, Research, and Applications. In M. O'Driscoll (Series Ed.) P. Dewe (Ed.) Retrieved from http://sk.sagepub.com/books/organizational-stress. doi:10.4135/9781452231235

Crawford, E. R., LePine, J. A., \& Rich, B. L. (2010). Linking job demands and resources to employee engagement and burnout: A theoretical extension and meta-analytic test. Journal of Applied Psychology, 95(5), 834-848.

Daderman, A. M., \& De Colli, D. (2014). The significance of the sense of coherence for various coping resources in stress situations used by police officers in on-the-beat service. International Journal of Occupational Medicine and Environmental Health, 27(1), 3-15. doi:10.2478/s13382-014-0227-2

Drach-Zahavy, A., \& Freund, A. (2007). Team effectiveness under stress: A structural contingency approach. Journal of Organizational Behavior, 28(4), 423-450. doi:10.1002/job.430

Eberez, S., Becker, R., \& Antoni, C. (2015). Work-related sense of coherence: A useful construct for occupational psychology? The Journal of Occupational and Organizational Psychology A \& O, 55, 115-131. doi:10.1026/09324089/a000056

Eriksson, M., \& Lindstrom, B. (2005). Validity of Antonovsky's sense of coherence scale: A systematic review. Journal of Epidemiology and Community Health, 59(6), 460-466. doi:10.1136/jech.2003.018085 
Eriksson, M., \& Lindstrom, B. (2006). Antonovsky's sense of coherence scale and the relation with health: A systematic review. Journal of Epidemiology and Community Health, 60(5), 376-381. doi:10.1136/jech.2005.041616

Eriksson, M., \& Lindstrom, B. (2007). Antonovsky's sense of coherence scale and its relation with quality of life: A systematic review. Journal of Epidemiology and Community Health, 61(11), 938-944. doi:10.1136/jech.2006.056028

Feldman, P. J., Cohen, S., Hamrick, N., \& Lepore, S. J. (2004). Psychological stress, appraisal, emotion and Cardiovascular response in a public speaking task. Psychology \& Health, 19(3), 353-368. doi:10.1080/0887044042000193497

Feldt. (1997). The role of sense of coherence in well-being at work: Analysis of main and moderator effects. Work \& Stress, 11(2), 134-147. doi:10.1080/02678379708256830

Feldt, Kivimaki, M., Rantala, A., \& Tolvanen, A. (2004). Sense of coherence and work characteristics: A cross-lagged structural equal model among managers. Journal of Occupational and Organizational Psychology, 77, 323-342.

Feldt, Leskinen, E., Kinnunen, U., \& Mauno, S. (2000). Longitudinal factor analysis models in the assessment of the stability of sense of coherence. Personality and Individual Differences, 28(2), 239-257. doi:Doi 10.1016/S0191-8869(99)00094-X

Feldt, Leskinen, E., Koskenvuo, M., Suominen, S., Vahtera, J., \& Kivimaki, M. (2011). Development of sense of coherence in adulthood: a person-centered approach. The population-based HeSSup cohort study. Quality of Life Research, 20(1), 69-79. doi:10.1007/s11136-010-9720-7 
Feldt, T., Leskinen, E., \& Kinnunen, U. (2005). Structural invariance and stability of sense of coherence: A longitudinal analysis of two groups with different employment experiences. Work and Stress, 19(1), 68-83. doi:10.1080/02678370500084441

Fisher, C. D. (1993). Boredom at work: A neglected concept. Human Relations, 46(3), 395-417. doi:10.1177/001872679304600305

Flannery, R. B., \& Flannery, G. J. (1990). Sense of coherence, life stress, and psychological distress: A prospective methodological inquiry. Journal of Clinical Psychology, 46(4), 415-420.

Flensborg-Madsen, T., Ventegodt, S., \& Merrick, J. (2005). Sense of coherence and physical health. A review of previous findings. Thescientificworldjournal, 5, 665-673. doi:10.1100/tsw.2005.85

Frenz, A. W., Carey, M. P., \& Jorgensen, R. S. (1993). Psychometric evaluation of Antonovsky's sense of coherence scale. Psychological Assessment, 5(2), 145-153.

Geyer, S. (1997). Some conceptual considerations on the sense of coherence. Social Science \& Medicine, 44(12), 1771-1779. doi:10.1016/s0277-9536(96)00286-9

Gilbar, O. (1998). Relationship between burnout and sense of coherence in health social workers. Social Work in Health Care, 26(3), 39-49. doi:10.1300/J010v26n03_03

Gomes, A. R., Faria, S., \& Gonçalves, A. M. (2013). Cognitive appraisal as a mediator in the relationship between stress and burnout. Work \& Stress, 27(4), 351-367. doi:10.1080/02678373.2013.840341

Gräser, S. (2003). Hochschule und gesundheit: Salutogenese am arbeitsplatz universität. Lengerich, Germany: Pabst. 
Greenhalgh, L. (1982). Maintaining organizational effectiveness during organizational retrenchment. Journal of Applied Behavioral Sciences, 18(155-170).

Hackman, J. R., \& Oldham, G. R. (1980). Work redesign. Reading, MA: Addison-Wesley.

Hakanen, J. J., Feldt, T., \& Leskinen, E. (2007). Change and stability of sense of coherence in adulthood: Longitudinal evidence from the Healthy Child study. Journal of Research in Personality, 41(3), 602-617. doi:10.1016/j.jrp.2006.07.001

Hart, K. E., Wilson, T. L., \& Hittner, J. B. (2006). A psychosocial resilience model to account for medical well-being in relation to sense of coherence. J Health Psychol, 11(6), 857862. doi:10.1177/1359105306069082

Hartley, J., Jacobson, D., Klandermans, B., \& Van Vuuren, T. (1991). Job Insecurity. Coping with jobs at risk. Sage, London.

Holmberg, S., Thelin, A., \& Stiernström, E.-L. (2004). Relationship of Sense of Coherence to other psychosocial indices. European Journal of Psychological Assessment, 20(4), 227236. doi:10.1027/1015-5759.20.4.227

Howard, J. L., Gagné, M., Morin, A. J. S., \& Forest, J. (2016). Using bifactor exploratory structural equation modeling to test for a continuum structure of motivation. Journal of Management. doi:10.1177/0149206316645653

Hurrell, J. J. J., \& McLaney, M. A. (1988). Exposure to job stress: A new psychometric instrument. Scand J Work Environ Health, 14, 27-28.

Jenny, G. J., Bauer, G. F., Vinje, H. F., Vogt, K., \& Torp, S. (2016). The application of salutogenesis to work. In M. B. Mittelmark, S. Sagy, M. Erikkson, G. F. Bauer, J. M. Pelikan, B. Lindstrom, \& G. A. Espenes (Eds.), The handbook of salutogenesis (pp. 197210). DOI 10.1007/978-3-319-04600-6: Springer. 
Jex, S. M., \& Britt, T. W. (2014). Organizational psychology: A scientist-practitioner approach (3rd ed.). Hoboken, NJ: Wiley.

Jex, S. M., \& Yankelevich, M. (Eds.). (2008) The Sage Handbook of Organizational Behavior (Vols. 1). Los Angeles: Sage.

Johnson, K. L., Yorkston, K. M., Klasner, E. R., Kuehn, C. M., Johnson, E., \& Amtmann, D. (2004). The cost and benefits of employment: a qualitative study of experiences of persons with multiple sclerosis. Arch Phys Med Rehabil., 85. doi:10.1016/s00039993(03)00614-2

Jorgensen, R. S., Frankowski, J. J., \& Carey, M. P. (1999). Sense of coherence, negative life events and appraisal of physical health among university students. Personality and Individual Differences, 27(6), 1079-1089. doi:10.1016/s0191-8869(99)00050-1

Kahn, R. L., Wolfe, D. M., Quinn, R. P., Snoek, J. D., \& Rosenthal, R. A. (1964). Organizational stress: Studies in role conflict and ambiguity. New York, NY: Wiley.

Kalimo, Pahkin, K., \& Mutanen, P. (2002). Work and personal resources as long-term predictors of well-being. Stress and Health, 18(5), 227-234. doi:10.1002/smi.949

Kalimo, R., Pahkin, K., Mutanen, P., \& Toppinen-Tanner, S. (2003). Staying well or burning out at work: work characteristics and personal resources as long-term predictors. Work and Stress, 17. doi:10.1080/0267837031000149919

Kalimo, R., \& Vuori, J. (1990). Work and sense of coherence--resources for competence and life satisfaction. Behavioral Medicine, 16(2), 76-89. doi:10.1080/08964289.1990.9934595

King, L. A., \& King, D. W. (1990). Role confict and role ambiguity: A critical assessment of construct validity. Psychological Bulletin, 107, 48-64. 
Kivimaki, Feldt, T., Vahtera, J., \& Nurmi, J. E. (2000). Sense of coherence and health: Evidence from two cross-lagged longitudinal samples. Social Science \& Medicine, 50(4), 583-597. doi:10.1016/s0277-9536(99)00326-3

Kivimäki, Vahtera, J., Thomson, L., Griffiths, A., Cox, T., \& Pentti, J. (1997). Psychosocial factors predicting employee sickness absence during economic decline. Journal of Applied Psychology, 82, 858-872.

Kivimäki, M., Elovainio, M., Vahtera, J., Nurmi, J-E., Feldt, T., Keltinkangas-Järvinen, L., \& Pentti, J. (2002). Sense of coherence as a mediator between hostility and health: Sevenyear prospective study on female employees. Journal of Psychosomatic Research, 52, 239-247.

Kouvonen, A. M., Vaananen, A., Woods, S. A., Heponiemi, T., Koskinen, A., \& ToppinenTanner, S. (2008). Sense of coherence and diabetes: a prospective occupational cohort study. Bmc Public Health, 8, 46. doi:10.1186/1471-2458-8-46

Krantz, G., \& Ostergren, P. O. (2004). Does it make sense in a coherent way? Determinants of sense of coherence in Swedish women 40 to 50 years of age. International Journal of Behavioral Medicine, 11(1), 18-26. doi:DOI 10.1207/s15327558ijbm1101_3

Kuuppelomaki, M., \& Utriainen, P. (2003). A 3 year follow-up study of health care students' sense of coherence and related smoking, drinking and physical exercise factors. International Journal of Nursing Studies, 40(4), 383-388. doi:10.1016/S00207489(02)00103-7

Larsson, G., Kallenberg, K., Setterlind, S., \& Starrin, B. (1994). Health and loss of a family member: Impact of Sense of Coherence. International Journal of Health Science, 5, 5-11. 
Lazarus, R. S. (1991). Progress on a cognitive-motivational-relational theory of emotion. American Psychologist, 46(8), 819-834.

Lazarus, R. S., \& Folkman, S. (1984). Stress, appraisal, and coping. New York: Springer.

LePine, J. A., LePine, M. A., \& Jackson, C. L. (2004). Challenge and hindrance stress: Relationships with exhaustion, motivation to learn, and learning performance. Journal of Applied Psychology, 89, 883-891.

Lepine, J. A., Podsakoff, N. P., \& Lepine, M. A. (2005). A meta-analytic test of the challenge stressor-hindrance stressor framework: An explanation for inconsistent relationships among stressors and performance. Academy of Management Journal, 48(5), 764-775.

Levert, T., Lucas, M., \& Ortlepp, K. (2000). Burnout in psychiatric nurses: Contributions of the work environment and a Sense of Coherence. South African Journal of Psychology, $30(2), 36-43$.

Liukkonen, V., Virtanen, P., Vahtera, J., Suominen, S., Sillanmaki, L., \& Koskenvuo, M. (2010). Employment trajectories and changes in sense of coherence. European Journal of Public Health, 20(3), 293-298. doi:10.1093/eurpub/ckp171

Lowin, A. (1968). Participative decision making: A model, literature critique, and prescriptions for research. Organizational Behavior and Human Performance, 3, 68-106.

Luyckx, K., Goossens, E., Apers, S., Rassart, J., Klimstra, T., Dezutter, J., \& Moons, P. (2012). The 13-item sense of soherence scale in Dutch-speaking adolescents and young adults: Structural validity, age trends, and chronic disease. Psychologica Belgica, 52(4), 351368. 
Marsh, H., Morin, A., Parker, P., \& Kaur, G. (2014). Exploratory structural equation modeling: An integration of the best features of exploratory and confirmatory factor analysis. Annual Review of Clinical Psychology, 10, 85-110.

Mcsherry, W. C., \& Holm, J. E. (1994). Sense of Coherence: Its effects on psychological and physiological processes prior to, during, and after a stressful situation. Journal of Clinical Psychology, 50(4), 476-487. doi:Doi 10.1002/1097-4679(199407)50:4<476::AidJclp2270500402>3.0.Co;2-9

Morin, A. J. S., Arens, A. K., \& Marsh, H. W. (2015). A bifactor exploratory structural equation modeling framework for the identification of distinct sources of construct-relevant psychometric multidimensionality. Structural Equation Modeling: A Multidisciplinary Journal, 23(1), 116-139. doi:10.1080/10705511.2014.961800

Morita, Y., Ohta, M., Inoue, T., Honda, T., Konno, Y., Eguchi, Y., \& Yamato, H. (2014). Sense of coherence is significantly associated with both metabolic syndrome and lifestyle in Japanese computer software office workers. International Journal of Occupational Medicine and Environmental Health, 27(6), 967-979. doi:10.2478/s13382-014-0322-4

Muthén, L. K., \& Muthén, B. O. (2014). Mplus user's guide. Los Angeles, CA: Muthén \& Muthén.

Neuner, B., Miller, P., Maulhardt, A., Weiss-Gerlach, E., Neumann, T., Lau, A., . . Spies, C. (2006). Hazardous alcohol consumption and sense of coherence in emergency department patients with minor trauma. Drug and Alcohol Dependence, 82(2), 143-150. doi:10.1016/j.drugalcdep.2005.09.001 
Nilsson, Holmgren, L., \& Westman, G. (2000). Sense of coherence in different stages of health and disease in northern Sweden: gender and psychosocial differences. Scand J Prim Health Care, 18. doi:10.1080/02813430050202497

Nilsson, Leppert, J., Simonsson, B., \& Starrin, B. (2010). Sense of coherence and psychological well-being: Improvement with age. J Epidemiol Community Health, 64. doi:10.1136/jech.2008.081174

Ohly, S., \& Fritz, C. (2010). Work characteristics, challenge appraisal, creativity, and proactive behavior: A multi-level study. Journal of Organizational Behavior, 31, 543-565.

Pallant, J. F., \& Lae, L. (2002). Sense of coherence, well-being, coping and personality factors: further evaluation of the sense of coherence scale. Personality and Individual Differences, 33(1), 39-48. doi:Pii S0191-8869(01)00134-9

Doi 10.1016/S0191-8869(01)00134-9

Palsson, M.-B., Hallberg, I.R., Norberg, A., \& Björvell, H. (1996). Burnout, empathy and sense of coherence among Swedish district nurses before and after systematic clinical supervision. Scandinavian journal of caring sciences, 10, 21-26.

Pearsall, M. J., Ellis, A. P. J., \& Stein, J. H. (2009). Coping with challenge and hindrance stressors in teams: Behavioral, cognitive, and affective outcomes. Organizational Behavior and Human Decision Processes, 109(1), 18-28. doi:10.1016/j.obhdp.2009.02.002

Pejtersen, J. H., Kristensen, T. S., Borg, V., \& Bjorner, J. B. (2010). The second version of the Copenhagen Psychosocial Questionnaire. Scandinavian Journal of Public Health, 38, 824. doi:10.1177/1403494809349858 
Podsakoff, N. P., LePine, J. A., \& LePine, M. A. (2007). Differential challenge stressorhindrance stressor relationships with job attitudes, turnover intentions, turnover, and withdrawal behavior: a meta-analysis. J Appl Psychol, 92(2), 438-454. doi:10.1037/00219010.92 .2 .438

Poppius, E., Tenkanen, L., Kalimo, R., \& Heinsalmi, P. (1999). The sense of coherence, occupation and the risk of coronary heart disease in the Helsinki Heart Study. Social Science and Medicine, 49, 109-120.

Poppius, E., Virkkunen, H., Hakama, M., \& Tenkanen, L. (2006). The sense of coherence and incidence of cancer--role of follow-up time and age at baseline. Journal of Psychosomatic Research, 61(2), 205-211. doi:10.1016/j.jpsychores.2006.01.017

Pusswald, G., Fleck, M., Lehrner, J., Haubenberger, D., Weber, G., \& Auff, E. (2012). The "Sense of Coherence" and the coping capacity of patients with Parkinson disease. International Psychogeriatrics, 24(12), 1972-1979. doi:10.1017/S1041610212001330

Read, S., Aunola, K., Feldt, T., Leinonen, R., \& Ruoppila, I. (2005). The relationship between generalized resistance resources, sense of coherence, and health among Finnish people aged 65-69. European Psychologist, 10(3), 244-253. doi:10.1027/1016-9040.10.3.244

Richardson, C. G., \& Ratner, P. A. (2005). Sense of coherence as a moderator of the effects of stressful life events on health. Journal of Epidemiology and Community Health, 59(11), 979-984. doi:10.1136/jech.2005.036756

Sarenmalm, E. K., Browall, M., Persson, L. O., Fall-Dickson, J., \& Gaston-Johansson, F. (2013). Relationship of sense of coherence to stressful events, coping strategies, health status, and quality of life in women with breast cancer. Psycho-Oncology, 22(1), 20-27. doi:10.1002/pon.2053 
Schnyder, U., Buchi, S., Sensky, T., \& Klaghofer, R. (2000). Antonovsky's sense of coherence: Trait or state? Psychotherapy and Psychosomatics, 69(6), 296-302. doi:Doi $10.1159 / 000012411$

Searle, B. J., \& Auton, J. C. (2015). The merits of measuring challenge and hindrance appraisals. Anxiety Stress Coping, 28(2), 121-143. doi:10.1080/10615806.2014.931378

Selye, H. (1974). Stress without distress. Philadelphia: Lippincott.

Smith, P. M., Breslin, F. C., \& Beaton, D. E. (2003). Questioning the stability of sense of coherence. Soc Psychiatry Psychiatr Epidemiol, 38(9), 475-484. doi:10.1007/s00127003-0654-z

Spector, P. E., \& Jex, S. M. (1998). Development of four self-report measures of job stressors and strain: Interpersonal Conflict at Work Scale, Organizational Constratints Scale, Quantitative Workload Inventory, and Physical Symptoms Inventory. Journal of Occupational Health Psychology, 3(4), 356-367.

Strumpfer. (2001). Psychometric properties of an instrument to measure resilience in adults. South African Journal of Psychology, 31(1), 36-44.

Suominen, S., Helenius, H., Blomberg, H., Uutela, A., \& Koskenvuo, M. (2001). Sense of coherence as a predictor of subjective state of health: Results of 4 years of follow-up of adults. Journal of Psychosomatic Research, 50, 77-86.

Super, S., Verschuren, W. M., Zantinge, E. M., Wagemakers, M. A., \& Picavet, H. S. (2014). A weak sense of coherence is associated with a higher mortality risk. J Epidemiol Community Health, 68(5), 411-417. doi:10.1136/jech-2013-203085 
Surtees, Wainwright, N., Luben, R., Khaw, K. T., \& Day, N. (2003). Sense of coherence and mortality in men and women in the EPIC-Norfolk United Kingdom prospective cohort study. American Journal of Epidemiology, 158(12), 1202-1209. doi:10.1093/aje/kwg272

Surtees, Wainwright, N. W., \& Khaw, K. T. (2006). Resilience, misfortune, and mortality: evidence that sense of coherence is a marker of social stress adaptive capacity. Journal of Psychosomatic Research, 61(2), 221-227. doi:10.1016/j.jpsychores.2006.02.014

Surtees, Wainwright, N. W., Luben, R. L., Wareham, N. J., Bingham, S. A., \& Khaw, K. T. (2007). Adaptation to social adversity is associated with stroke incidence: evidence from the EPIC-Norfolk prospective cohort study. Stroke, 38(5), 1447-1453. doi:10.1161/STROKEAHA.106.473116

Tartas, M., Walkiewicz, M., Budzinski, W., Majkowicz, M., \& Wojcikiewicz, K. (2014). The sense of coherence and styles of success in the medical career: a longitudinal study. BMC Medical Education, 14, 254. doi:10.1186/s12909-014-0254-5

Tetrick, L. E., \& LaRocco, J. M. (1987). Understanding, prediction, and control as moderators of the relationships between perceived stress, satisfaction, and psychological well-being. $J$ Appl Psychol, 72, 538-543.

Tomotsune, Y., Sasahara, S., Umeda, T., Hayashi, M., Usami, K., Yoshino, S., . . Matsuzaki, I. (2009). The association of Sense of Coherence and coping profile with stress among Research Park City Workers in Japan. Industrial Health, 47(6), 664-672.

Tselebis, A., Moulou, A., \& Ilias, I. (2001). Burnout versus depression and sense of coherence: Study of Greek nursing staff. Nursing and Health Sciences, 3, 69-71. 
Tuckey, M. R., Searle, B. J., Boyd, C. M., Winefield, A. H., \& Winefield, H. R. (2015). Hindrances are not threats: advancing the multidimensionality of work stress. J Occup Health Psychol, 20(2), 131-147. doi:10.1037/a0038280

Urakawa, K., Yokoyama, K., \& Itoh, H. (2012). Sense of coherence is associated with reduced psychological responses to job stressors among Japanese factory workers.(Research article)(Report). BMC Research Notes, 5, 247.

Van der Colff, J. J., \& Rothmann. (2009). Occupational stress, sense of coherence, coping, burnout and work engagement of registered nurses in South Africa. South African Journal of Industrial Psychology, 35(1).

Vogt, K., Hakanen, J. J., Jenny, G. J., \& Bauer, G. F. (2016). Sense of coherence and the motivational process of the job-demands-resources model. Journal of Occupational Health Psychology, 21(2), 194-207. doi:10.1037/a0039899

Vogt, K., Jenny, G. J., \& Bauer, G. F. (2013). Comprehensibility, manageability and meaningfulness at work: Construct validity of a scale measuring workrelated sense of coherence. SA Journal of Industrial Psychology, 39(1). doi:10.4102/sajip.v39i1.1111

Volanen, S. M., Lahelma, E., Silventoinen, K., \& Suominen, S. (2004). Factors contributing to sense of coherence among men and women. European Journal of Public Health, 14(3), $322-330$.

Volanen, S. M., Suominen, S., Lahelma, E., Koskenvuo, M., \& Silventoinen, K. (2007). Negative life events and stability of sense of coherence: A five-year follow-up study of Finnish women and men. Scandinavian Journal of Psychology, 48(5), 433-441. doi:10.1111/j.1467-9450.2007.00598.x 
Wainwright, N. W. J., Surtees, P. G., Welch, A. A., Luben, R. N., Khaw, K. T., \& Bingham, S. A. (2008). Sense of coherence, lifestyle choices and mortality. Journal of Epidemiology and Community Health, 62(9), 829-831. doi:10.1136/jech.2007.066464

Webster, J. R., Beehr, T. A., \& Love, K. (2011). Extending the challenge-hindrance model of occupational stress: The role of appraisal. Journal of Vocational Behavior, 79(2), 505516. doi:10.1016/j.jvb.2011.02.001

Widmer, P. S., Semmer, N. K., Kälin, W., Jacobshagen, N., \& Meier, L. L. (2012). The ambivalence of challenge stressors: Time pressure associated with both negative and positive well-being. Journal of Vocational Behavior, 80(2), 422-433. doi:10.1016/j.jvb.2011.09.006

Wiegand, D. M., Chen, P. Y., Hurrell, J. J., Jex, S., Nakata, A., Nigam, J. A., . . Tetrick, L. E. (2012). A consensus method for updating psychosocial measures used in NIOSH health hazard evaluations. Journal of Organizational and Environmental Medicine, 54(3), 350355.

Wolff, A. C., \& Ratner, P. A. (1999). Stress, social support, and sense of coherence. Western Journal of Nursing Research, 21(2), 182-197. doi:Doi 10.1177/01939459922043820

Wurtz, E. T., Fonager, K., \& Mortensen, J. T. (2015). Association between sense of coherence in adolescence and social benefits later in life: a 12-year follow-up study. Bmj Open, 5(1). doi:10.1136/bmjopen-2014-006489

Zarzycka, B., \& Rydz, E. (2014). Explaining the relationship between post-critical beliefs and Sense of Coherence in Polish young, middle, and late adults. Journal of Religion \& Health, 53(3), 834-848. doi:10.1007/s10943-013-9680-7 
APPENDIX A

SoC AND NON-WORK OUTCOMES 


\begin{tabular}{|c|c|c|}
\hline VARIABLE & REFERENCE & RELATIONSHIP TO SoC \\
\hline Alcohol consumption & Neuner et al. (2006) & $\begin{array}{l}\text { - } \\
\text { SoC negatively associated to increased } \\
\text { alcohol consumption (as a result of failed } \\
\text { coping strategies) }\end{array}$ \\
\hline $\begin{array}{l}\text { Anxiety and } \\
\text { depression }\end{array}$ & Schnyder et al. (2000) & $\begin{array}{l}\text { SoC negatively associated with } \\
\text { anxiety/depression }\end{array}$ \\
\hline Cancer & Poppius et al. (2006) & $\begin{array}{l}\text { Those with weak SoC had higher relative } \\
\text { risk of cancer }(1.52) \text { than those with strong } \\
\text { SoC ( } 8 \text {-year follow-up) } \\
\text { Strong SoC associated with delayed onset } \\
\text { of cancer (men }>55 \text { years) }\end{array}$ \\
\hline Chronic stress & $\begin{array}{l}\text { Wolff and Ratner } \\
\text { (1999) }\end{array}$ & $\begin{array}{l}+ \\
\text { Weak SoC as adults associated with } \\
\text { experiences of childhood stressors (chronic } \\
\text { stress) (parental divorce, family stress, } \\
\text { physical abuse, and parental alcohol or } \\
\text { drug abuse) }\end{array}$ \\
\hline Coping strategies & $\begin{array}{l}\text { Sarenmalm, Browall, } \\
\text { Persson, Fall-Dickson, } \\
\text { and Gaston-Johansson } \\
\text { (2013) }\end{array}$ & $\begin{array}{l}+ \\
\text { (Weaker SoC were more likely to use } \\
\text { unhealthy coping strategies) }\end{array}$ \\
\hline Depression & Feldt (1997) & - \\
\hline Diabetes & Kouvonen et al. (2008) & $\begin{array}{l}\text { Weak SoC associated with } 46 \% \text { higher risk } \\
\text { of diabetes }\end{array}$ \\
\hline $\begin{array}{l}\text { Eating (health } \\
\text { behavior) }\end{array}$ & Morita et al. (2014) & $\begin{array}{l}\text { Morita et al. (2014)+ } \\
\text { Strong SoC individuals more likely to eat } \\
\text { at slow or moderate speed }\end{array}$ \\
\hline $\begin{array}{l}\text { General health/Well- } \\
\text { being }\end{array}$ & $\begin{array}{l}\text { Binkowska-Bury and } \\
\text { Januszewicz (2010), } \\
\text { Feldt (1997), Geyer } \\
\text { (1997), Jorgensen, } \\
\text { Frankowski, and Carey } \\
\text { (1999), Pallant and Lae } \\
\text { (2002), Poppius, } \\
\text { Tenkanen, Kalimo, and } \\
\text { Heinsalmi (1999), } \\
\text { Kivimaki et al. (2000), } \\
\text { Kivimäki (2002), } \\
\text { Cederblad and Hansson } \\
\text { (1996) }\end{array}$ & + \\
\hline
\end{tabular}




\begin{tabular}{|c|c|c|}
\hline $\begin{array}{l}\text { General living } \\
\text { conditions }\end{array}$ & Holmberg et al. (2004) & $\begin{array}{l}+ \\
\text { between SoC and general living } \\
\text { conditions }\end{array}$ \\
\hline $\begin{array}{l}\text { Healthy coping } \\
\text { strategies }\end{array}$ & Pusswald et al. (2012) & $\begin{array}{l}\text { - } \\
\text { SoC associated with depressive coping } \\
\text { styles }\end{array}$ \\
\hline $\begin{array}{l}\text { Health (in ages 65- } \\
69 \text { ) }\end{array}$ & $\begin{array}{l}\text { Read, Aunola, Feldt, } \\
\text { Leinonen, and } \\
\text { Ruoppila (2005) }\end{array}$ & $\begin{array}{l}+ \\
\text { Good cognitive functioning, physical } \\
\text { activity, marital status (in men) and SoC } \\
+ \\
\text { SoC and physical, social, \& mental health }\end{array}$ \\
\hline $\begin{array}{l}\text { Healthy coping } \\
\text { strategies }\end{array}$ & $\begin{array}{l}\text { Mcsherry and Holm } \\
\text { (1994) }\end{array}$ & $\begin{array}{l}+ \\
\text { Strong SoC individuals used more } \\
\text { approach coping strategies }\end{array}$ \\
\hline $\begin{array}{l}\text { Healthy coping } \\
\text { strategies }\end{array}$ & $\begin{array}{l}\text { Amirkhan and Greaves } \\
(2003)\end{array}$ & $\begin{array}{l}+ \\
\text { Higher SoC associated with non-avoidant } \\
\text { coping styles } \\
\text { Higher SoC associated with problem- } \\
\text { focused responses } \\
\text { Higher SoC associated with attempts to } \\
\text { resolve problems }\end{array}$ \\
\hline $\begin{array}{l}\text { Healthy coping } \\
\text { strategies }\end{array}$ & Pallant and Lae (2002) & $\begin{array}{l}+ \\
\text { Strong SoC individuals are more likely to } \\
\text { respond to stressor with adaptive strategies } \\
\text { SoC is positively correlated with physical } \\
\text { and psychological well-being }\end{array}$ \\
\hline $\begin{array}{l}\text { Healthy coping } \\
\text { strategies }\end{array}$ & $\begin{array}{l}\text { Tomotsune et al. } \\
(2009)\end{array}$ & $\begin{array}{l}+ \\
\text { Higher SoC individuals use problem- } \\
\text { focused coping } \\
\text { Lower SoC individuals use emotion- } \\
\text { focused coping }\end{array}$ \\
\hline $\begin{array}{l}\text { Healthy coping } \\
\text { strategies }\end{array}$ & $\begin{array}{l}\text { Surtees, Wainwright, } \\
\text { and Khaw (2006) }\end{array}$ & $\begin{array}{l}+ \\
\text { Higher SoC showed better preparation to } \\
\text { handle stressors of everyday life and use } \\
\text { resources at their disposal to counter those } \\
\text { stressors }\end{array}$ \\
\hline $\begin{array}{l}\text { Healthy coping } \\
\text { strategies }\end{array}$ & $\begin{array}{l}\text { Amirkhan and Greaves } \\
(2003)\end{array}$ & $\begin{array}{l}+ \\
\text { Higher SoC individuals adopted more } \\
\text { problem-solving and less avoidant } \\
\text { behavior }\end{array}$ \\
\hline $\begin{array}{l}\text { Healthy lifestyle (in } \\
\text { Japanese workers) }\end{array}$ & Morita et al. (2014) & $\begin{array}{l}+ \\
\text { Those with stronger SoC were more likely } \\
\text { to: walk for at least } 1 \text { hour a day, eat } \\
\text { slowly/moderate pace, and sleep for at } \\
\text { least } 6 \text { hours/night }\end{array}$ \\
\hline
\end{tabular}




\begin{tabular}{|c|c|c|}
\hline Life satisfaction & $\begin{array}{l}\text { Binkowska-Bury and } \\
\text { Januszewicz (2010), } \\
\text { Kalimo and Vuori } \\
\text { (1990) }\end{array}$ & + \\
\hline Locus of control & Johnson et al. (2004) & $\begin{array}{l}+ \\
\text { SoC } \text { and locus of control }\end{array}$ \\
\hline Locus of control & $\begin{array}{l}\text { Bengtsson-Tops and } \\
\text { Hansson (2001) }\end{array}$ & $\begin{array}{l}+ \\
\text { SoC and locus of control }\end{array}$ \\
\hline Mortality & Super et al. (2014) & $\begin{array}{l}\text { Weak SoC (compared with intermediate } \\
\text { SoC ) associated with higher all-cause } \\
\text { mortality risk (13.5-year follow-up) }\end{array}$ \\
\hline Mortality & $\begin{array}{l}\text { Wainwright et al. } \\
\text { (2008) }\end{array}$ & $\begin{array}{l}\text { - } \\
\text { Strong SoC associated with } 20 \% \text { reduced } \\
\text { risk of all-cause mortality ( } 8 \text {-year follow- } \\
\text { up) }\end{array}$ \\
\hline Mortality & $\begin{array}{l}\text { Surtees, Wainwright, } \\
\text { Luben, Khaw, and Day } \\
\text { (2003) }\end{array}$ & $\begin{array}{l}\text { Strong SoC associated with } 30 \% \text { reduction } \\
\text { in mortality from all causes, cardiovascular } \\
\text { disease, and cancer }\end{array}$ \\
\hline $\begin{array}{l}\text { Negative Affectivity } \\
\text { measures (e.g., } \\
\text { anxiety and } \\
\text { neuroticism) }\end{array}$ & $\begin{array}{l}\text { Bowman (1996), } \\
\text { Flannery and Flannery } \\
(1990)\end{array}$ & (2) \\
\hline Perceived health & $\begin{array}{l}\text { Eriksson and } \\
\text { Lindstrom (2006) }\end{array}$ & $\begin{array}{l}+ \\
\text { Association positive }-\mathrm{SoC} \text { and perceived } \\
\text { health (especially mental health); stronger } \\
\text { SoC = better perceived health in general } \\
\text { (for those with initial high SoC) }\end{array}$ \\
\hline Perceived health & $\begin{array}{l}\text { Nilsson, Holmgren, and } \\
\text { Westman (2000), } \\
\text { Suominen (2001), } \\
\text { Apers et al. (2013) }\end{array}$ & $\begin{array}{l}+ \\
\text { Low SoC associated with poor perceived } \\
\text { health } \\
+ \\
\text { SoC at } \mathrm{T} 1 \text { positively predicted all domains } \\
\text { of generic perceived health (physical, } \\
\text { emotional, social, and school functioning) } \\
\text { at T2 } \\
\text { SoC at } \mathrm{T} 1 \text { positively predicted three out of } \\
\text { five domains of disease-specific perceived } \\
\text { health (symptoms, physical appearance, } \\
\text { and cognitive problems) at } \mathrm{T} 2\end{array}$ \\
\hline $\begin{array}{l}\text { Perceived stress (in } \\
\text { psychotherapy } \\
\text { subjects) }\end{array}$ & $\begin{array}{l}\text { Frenz, Carey, and } \\
\text { Jorgensen (1993) }\end{array}$ & $\begin{array}{l}\text { - } \\
\text { soC scores and self-reports of perceived } \\
\text { stress }\end{array}$ \\
\hline
\end{tabular}




\begin{tabular}{|c|c|c|}
\hline Physical activity & $\begin{array}{l}\text { Kuuppelomaki and } \\
\text { Utriainen (2003) }\end{array}$ & $\begin{array}{l}+ \\
\text { Physical activity related to strength of SoC }\end{array}$ \\
\hline Physical activity & Morita et al. (2014) & $\begin{array}{l}+ \\
\text { People with stronger SoC more likely to } \\
\text { walk for at least } 1 \text { hour/day }\end{array}$ \\
\hline Physiological distress & $\begin{array}{l}\text { Mcsherry and Holm } \\
\text { (1994) }\end{array}$ & $\begin{array}{l}\text { Low SoC individuals displayed more } \\
\text { psychological and physiological distress }\end{array}$ \\
\hline $\begin{array}{l}\text { Psychological and } \\
\text { physical health }\end{array}$ & $\begin{array}{l}\text { Flensborg-Madsen, } \\
\text { Ventegodt, and } \\
\text { Merrick (2005) }\end{array}$ & $\begin{array}{l}+ \\
\text { Lit review: concluded that SoC is highly } \\
\text { related to psychological aspects of health } \\
\text { but that there is not a strong association } \\
\text { with physical health }\end{array}$ \\
\hline $\begin{array}{l}\text { Psychological health } \\
\text { indicators }\end{array}$ & $\begin{array}{l}\text { Eriksson and } \\
\text { Lindstrom (2005) }\end{array}$ & $\begin{array}{l}+ \\
\text { SoC and self-esteem, quality of life, and } \\
\text { optimism } \\
- \\
\text { SoC and anxiety and depression }\end{array}$ \\
\hline Psychosocial health & $\begin{array}{l}\text { Benz, Angst, Lehmann, } \\
\text { and Aeschlimann } \\
(2013)\end{array}$ & SoC and psychosocial health dimensions \\
\hline Quality of Life & Pusswald et al. (2012) & $\begin{array}{l}+ \\
\text { SoC is above all a predictor for QoL, well- } \\
\text { being, and coping }\end{array}$ \\
\hline Quality of life & $\begin{array}{l}\text { Eriksson and } \\
\text { Lindstrom (2007) }\end{array}$ & $\begin{array}{l}+ \\
\text { SoC and quality of life } \\
\text { Predictor - SoC predicts quality of live } \\
\text { (review) }\end{array}$ \\
\hline Quality of life & Tartas et al. (2014) & $\begin{array}{l}+ \\
\text { Med students with high SoC had highest } \\
\text { quality of life later on }\end{array}$ \\
\hline $\begin{array}{l}\text { Reality of human } \\
\text { existence }\end{array}$ & $\begin{array}{l}\text { Skaggs \& Barron } \\
(2006)\end{array}$ & $\begin{array}{l}+ \\
\text { SoC associated with a person's sense of } \\
\text { social consciousness, sense of order, sense } \\
\text { of personal identity, a reason for existence, } \\
\text { sense that life is meaningful, belief that life } \\
\text { is manageable, and stable understanding of } \\
\text { others, self and lifell (p. 562) }\end{array}$ \\
\hline $\begin{array}{l}\text { Religiosity (Post- } \\
\text { Critical Belief) in } \\
\text { women and men in } \\
\text { early, middle, and } \\
\text { late adulthood (18-79 } \\
\text { years) }\end{array}$ & $\begin{array}{l}\text { Zarzycka and Rydz } \\
\text { (2014) }\end{array}$ & $\begin{array}{l}+ \\
\text { The salutogenic function of religiosity is } \\
\text { related to age and gender } \\
\text { - In women it is most strongly marked } \\
\text { in late adulthood } \\
\text { - In men it is most strongly marked in } \\
\text { middle adulthood }\end{array}$ \\
\hline
\end{tabular}




\begin{tabular}{|c|c|c|}
\hline Resilience & Hart et al. (2006) & $\begin{array}{l}+ \\
\text { SoC positively associated with measures of } \\
\text { psychological resilience }\end{array}$ \\
\hline $\begin{array}{l}\text { Sleep (health } \\
\text { behavior) }\end{array}$ & Morita et al. (2014) & $\begin{array}{l}+ \\
\text { Strong SoC individuals more likely to } \\
\text { sleep for at least } 6 \text { hours/night }\end{array}$ \\
\hline Social support & $\begin{array}{l}\text { Strang and Strang } \\
(2001)\end{array}$ & $\begin{array}{l}+ \\
\text { Positive effect of social support on SoC } \\
\text { Social support increases people's ability to } \\
\text { cope with potential stressors in life (by } \\
\text { providing people with belief that their life } \\
\text { has more meaning and is more } \\
\text { manageable) }\end{array}$ \\
\hline Social support & $\begin{array}{l}\text { Volanen, Lahelma, } \\
\text { Silventoinen, and } \\
\text { Suominen (2004) }\end{array}$ & $\begin{array}{l}+ \\
\text { Likely reciprocal relationships strong SoC } \\
\text { and social relationships and support (with } \\
\text { good social relationships and support } \\
\text { contributing to a strong SoC and a strong } \\
\text { SoC facilitating the acquisition of social } \\
\text { support and relationships) }\end{array}$ \\
\hline $\begin{array}{l}\text { Social } \\
\text { support/anchorage }\end{array}$ & $\begin{array}{l}\text { Krantz and Ostergren } \\
(2004)\end{array}$ & $\begin{array}{l}\text { Low social support and a lack of social } \\
\text { anchorage were predictors of low SoC in } \\
\text { adult women }\end{array}$ \\
\hline Stability & Feldt et al. (2011) & $\begin{array}{l}+ \\
\text { Continuous increase in SoC over time, } \\
\text { irrespective of age of adult; High SOC, } \\
\text { rather than higher age, seems to determine } \\
\text { a stable development of the SOC. }\end{array}$ \\
\hline Stability & Luyckx et al. (2012) & $\begin{array}{l}+ \\
\text { SoC increased with age through teens and } \\
\text { twenties; } \\
\text { High school and college students did not } \\
\text { differ on mean SoC scores, but employed } \\
\text { young adults scored significantly higher }\end{array}$ \\
\hline Stability & $\begin{array}{l}\text { Volanen, Suominen, } \\
\text { Lahelma, Koskenvuo, } \\
\text { and Silventoinen } \\
(2007)\end{array}$ & $\begin{array}{l}\text { - Negative life events decreased level of } \\
\text { SoC (irrespective of timing of event; the } \\
\text { more recent the life event, the lower the } \\
\text { SoC) } \\
\text { - Strong SoC did not protect SoC from } \\
\text { declining at } 15 \text { year follow up } \\
\text { - SoC related to negative changes in } \\
\text { people's environment } \\
\text { Initially strong SoC was not more stable } \\
\text { than initially mediocre or weak SoC }\end{array}$ \\
\hline
\end{tabular}




\begin{tabular}{|c|c|c|}
\hline Stability & Hakanen et al. (2007) & $\begin{array}{l}\text { Stability demonstrated in those with a high } \\
\text { SoC level (Finnish, ages 44-57) }\end{array}$ \\
\hline Stability & $\begin{array}{l}\text { Larsson, Kallenberg, } \\
\text { Setterlind, and Starrin } \\
\text { (1994) }\end{array}$ & $\begin{array}{l}\text { Stability demonstrated in those with an } \\
\text { initial high SoC when experienced loss of } \\
\text { family member }\end{array}$ \\
\hline Stability & Alm (2001) & $\begin{array}{l}\text { Stability demonstrated in those with an } \\
\text { initial high SoC when experienced } \\
\text { unemployment }\end{array}$ \\
\hline Stability & $\begin{array}{l}\text { Antonovsky (1979, } \\
\text { 1987b) }\end{array}$ & $\begin{array}{l}\text { Major later life crises are more likely to } \\
\text { undermine the SoC of those with an } \\
\text { initially weak or mediocre SoC than those } \\
\text { with an initially strong SoC }\end{array}$ \\
\hline $\begin{array}{l}\text { Stability (from } \\
\text { teenage to young } \\
\text { adulthood) }\end{array}$ & $\begin{array}{l}\text { Wurtz, Fonager, and } \\
\text { Mortensen }(2015)\end{array}$ & $\begin{array}{l}\text { SoC increased significantly and mostly in } \\
\text { girls } \\
\text { - SoC - } 7 \text { may serve as a predictor for } \\
\text { social life event outcomes and facilitate } \\
\text { early identification and selective approach } \\
\text { to support teenage girls with a weak SoC } \\
\text { - From adolescence to young adulthood, } \\
\text { SoC -7 was relatively unstable }\end{array}$ \\
\hline Stress responses & $\begin{array}{l}\text { Urakawa, Yokoyama, } \\
\text { and Itoh (2012) }\end{array}$ & $\begin{array}{l}\text { - } \\
\text { SoC was inversely associated with tension, } \\
\text { fatigue, anxiety, depression and subjective } \\
\text { symptoms in males, and tension, } \\
\text { depression and subjective symptoms in } \\
\text { females. }\end{array}$ \\
\hline $\begin{array}{l}\text { Stressful life events } \\
\text { (in people }>30 \text { years, } \\
\text { after } 1 \text { year) }\end{array}$ & $\begin{array}{l}\text { Richardson and Ratner } \\
\text { (2005) }\end{array}$ & $\begin{array}{l}\text { Buffer - SoC buffers the impact of recent } \\
\text { stressful life events on self-rated health }\end{array}$ \\
\hline Stroke Incidence & Surtees et al. (2007) & $\begin{array}{l}\text { - } \\
\text { SoC associated with } 25 \% \text { reduced rate of } \\
\text { stroke; Strong SoC associated with } 40 \% \\
\text { reduced rate of stroke }\end{array}$ \\
\hline Support & Nilsson et al. (2000) & $\begin{array}{l}\text { - } \\
\text { sow SoC associated with low social } \\
\text { Association negative - SoC scores and } \\
\text { poor perceived health }\end{array}$ \\
\hline Test Anxiety & $\begin{array}{l}\text { Cohen, Ben-Zur, and } \\
\text { Rosenfeld (2008) }\end{array}$ & - \\
\hline Vulnerability & Hart et al. (2006) & $\begin{array}{l}\text { SoC negatively associated with measures } \\
\text { of psychosocial vulnerability }\end{array}$ \\
\hline $\begin{array}{l}\text { Weight (health } \\
\text { behavior) }\end{array}$ & Morita et al. (2014) & $\begin{array}{l}\text { - Strong SoC individuals less likely to be } \\
\text { overweight }\end{array}$ \\
\hline
\end{tabular}




\section{APPENDIX B}

SoC AND WORK-RELATED OUTCOMES 


\begin{tabular}{|c|c|c|}
\hline VARIABLE & REFERENCE & RELATIONSHIP TO SoC \\
\hline Absence rate & Kivimäki et al. (1997) & $\begin{array}{l}\text { SoC and negative life events predicted } \\
\text { forthcoming absence rates }\end{array}$ \\
\hline $\begin{array}{l}\text { Achievement (in } \\
\text { social workers) }\end{array}$ & $\begin{array}{l}\text { Baker, North, and Smith } \\
\text { (1997) }\end{array}$ & $\begin{array}{l}+ \\
\text { SoC positively related to sense of } \\
\text { personal achievement }\end{array}$ \\
\hline Burnout & $\begin{array}{l}\text { Kalimo, Pahkin, and } \\
\text { Mutanen (2002); Kalimo, } \\
\text { Pahkin, Mutanen, and } \\
\text { Toppinen-Tanner (2003), } \\
\text { Palsson (1996), Tselebis } \\
\text { (2001) }\end{array}$ & - \\
\hline $\begin{array}{l}\text { Burnout/emotional } \\
\text { exhaustion (in } \\
\text { social workers) }\end{array}$ & Gilbar (1998) & $\begin{array}{l}\text { Strong SoC causes less experience of } \\
\text { burnout than those with weak SoC }\end{array}$ \\
\hline Burnout (in nurses) & $\begin{array}{l}\text { Basinska, Andruszkiewicz, } \\
\text { and Grabowska (2011) }\end{array}$ & $\begin{array}{l}\text { SoC negatively associated with burnout } \\
\text { behavior in nurses }\end{array}$ \\
\hline $\begin{array}{l}\text { Burnout (in social } \\
\text { workers) }\end{array}$ & $\begin{array}{l}\text { Baker, North, and Smith } \\
\text { (1997) }\end{array}$ & $\begin{array}{l}- \\
\text { Strong SoC causes less experience of } \\
\text { burnout than those with weak SoC }\end{array}$ \\
\hline Conscientiousness & Strumpfer (2001) & $\begin{array}{l}+ \\
\text { SoC positively associated with } \\
\text { conscientiousness }\end{array}$ \\
\hline Career Movement & Liukkonen et al. (2010) & $\begin{array}{l}+ \\
\text { SoC and upward career movement; } \\
\text { effects of employment trajectory on } \\
\text { SoC were strongest among employees } \\
<30 \text { years }\end{array}$ \\
\hline Engagement & $\begin{array}{l}\text { Vogt, Hakanen, Jenny, and } \\
\text { Bauer (2016) }\end{array}$ & $\begin{array}{l}+ \\
\text { SoC predicts work engagement }\end{array}$ \\
\hline Engagement & Van der Colff (2009) & $\begin{array}{l}+ \\
\text { Strong SoC predicted work engagement }\end{array}$ \\
\hline $\begin{array}{l}\text { Exhaustion (in } \\
\text { social workers) }\end{array}$ & Baker et al. (1997) & $\begin{array}{l}\text { SoC inversely related to emotional } \\
\text { exhaustion and depersonalization }\end{array}$ \\
\hline $\begin{array}{l}\text { Exhaustion, } \\
\text { depersonalization, } \\
\text { and burnout } \\
\text { (nurses) }\end{array}$ & $\begin{array}{l}\text { Levert, Lucas, and Ortlepp } \\
(2000)\end{array}$ & $\begin{array}{l}+ \\
\text { SoC and all factors of the work } \\
\text { environment correlated with emotional } \\
\text { exhaustion and depersonalization } \\
\text { *Multiple regression analyses showed } \\
\text { SoC and work load to explain a large } \\
\text { proportion of both emotional exhaustion } \\
\text { and depersonalization }\end{array}$ \\
\hline
\end{tabular}




\begin{tabular}{|c|c|c|}
\hline Financial health & $\begin{array}{l}\text { Barnard, Peters, and Muller } \\
\text { (2010) }\end{array}$ & + \\
\hline $\begin{array}{l}\text { Healthy coping } \\
\text { strategies }\end{array}$ & $\begin{array}{l}\text { Daderman and De Colli } \\
\text { (2014) }\end{array}$ & $\begin{array}{l}+ \\
\text { SoC is a significant variant in resources } \\
\text { used by police officers to cope with } \\
\text { stress }\end{array}$ \\
\hline Income & & $\begin{array}{l}+ \\
\text { Med students with high SoC have } \\
\text { higher income later on }\end{array}$ \\
\hline Job commitment & Strumpfer (2001) & $\begin{array}{l}+ \\
\text { SoC positively associated with job } \\
\text { commitment }\end{array}$ \\
\hline Job commitment & Strumpfer \& Mlonzi (2001) & + \\
\hline Job control & $\begin{array}{l}\text { Holmberg, Thelin, \& } \\
\text { Stiernstrom (2004) }\end{array}$ & $\begin{array}{l}+ \\
\text { between SoC and job control }\end{array}$ \\
\hline Job demand & $\begin{array}{l}\text { Holmberg, Thelin, \& } \\
\text { Stiernstrom (2004) }\end{array}$ & $\begin{array}{l}\text { between SoC and job demand } \\
\text { (Job demand was consistently correlated } \\
\text { to both a strong and weak SoC) }\end{array}$ \\
\hline Job demands & Fourie et al. (2008) & $\begin{array}{l}\text { SoC predicts perceived low job } \\
\text { demands }\end{array}$ \\
\hline Job insecurity & Feldt et al. (2000) & $\begin{array}{l}\text { Low job insecurity related to strong } \\
\text { SoC }\end{array}$ \\
\hline Job resources & Vogt et al. (2016) & $\begin{array}{l}+ \\
\text { SoC predicts job resources (reciprocal } \\
\text { relationship) } \\
* \text { Mediator }- \text { SoC mediates relationship } \\
\text { between job resources and work } \\
\text { engagement }\end{array}$ \\
\hline Job resources & Fourie et al. (2008) & $\begin{array}{l}\text { SoC positively predicts perceived high } \\
\text { availability of job resources }\end{array}$ \\
\hline Job satisfaction & Strumpfer (2001) & $\begin{array}{l}+ \\
\text { SoC positively associated with job } \\
\text { satisfaction }\end{array}$ \\
\hline Job satisfaction & Rothmann (2001) & + \\
\hline Job satisfaction & Strumpfer et al. (2003) & + \\
\hline Job stressors & Kinman (2008) & $\begin{array}{l}\text { Those with stronger SoC reported lower } \\
\text { levels of all types of job stressors } \\
\text { Moderator - employees with stronger } \\
\text { SoC might be protected from negative } \\
\text { effects of some job-related stressors }\end{array}$ \\
\hline
\end{tabular}




\begin{tabular}{|c|c|c|}
\hline $\begin{array}{l}\text { Mental Health and } \\
\text { work } \\
\text { characteristics } \\
\text { (male employees } \\
20-40 \text { ) }\end{array}$ & Togari \& Yamazaki (2012) & $\begin{array}{l}\text { Mediator - SoC mediated relationship of } \\
\text { psychological work characteristics on } \\
\text { mental health; *SoC is enhanced by a } \\
\text { positive psychosocial work environment } \\
\text { (i.e., flexibility, opportunity to increase } \\
\text { one's skills and decision-making) }\end{array}$ \\
\hline $\begin{array}{l}\text { Organizational } \\
\text { climate }\end{array}$ & Feldt et al. (2000) & $\begin{array}{l}+ \\
\text { Good organizational climate related to } \\
\text { strong SoC }\end{array}$ \\
\hline $\begin{array}{l}\text { Personal } \\
\text { achievement }\end{array}$ & $\begin{array}{l}\text { Baker, North, and Smith } \\
\text { (1997) }\end{array}$ & + \\
\hline $\begin{array}{l}\text { Physical and } \\
\text { psychological } \\
\text { health }\end{array}$ & Kinman (2008) & $\begin{array}{l}\text { - } \\
\text { Those with stronger SoC were in better } \\
\text { psychological and physical health than } \\
\text { those with weaker SoC }\end{array}$ \\
\hline $\begin{array}{l}\text { Psychiatric events } \\
\text { (in context of } \\
\text { organizational } \\
\text { merger) }\end{array}$ & Pahkin et al. (2011) & $\begin{array}{l}\text { - } \\
\text { Weaker SoC at premerger = at higher } \\
\text { and of perceiving org change negatively } \\
\text { and had elevated risk of postmerger } \\
\text { psychiatric events } \\
\text { Stronger SoC at premerger was a } \\
\text { protective factor for mental health when } \\
\text { the employee experiences negative } \\
\text { changes during an org change }\end{array}$ \\
\hline Sense of burden & $\begin{array}{l}\text { Hiyoshi-Taniguchi, Becker, } \\
\text { \& Kinoshita et al. (2013) }\end{array}$ & $\begin{array}{l}\text { - } \\
\text { High SoC substantially mitigated care- } \\
\text { givers' sense of burden (which could } \\
\text { ultimately reduce burnout, neglect, and } \\
\text { abuse of homebound elderly) }\end{array}$ \\
\hline Social network & $\begin{array}{l}\text { Holmberg, Thelin, \& } \\
\text { Stiernstrom (2004) }\end{array}$ & $\begin{array}{l}+ \\
\text { between SoC and social support }\end{array}$ \\
\hline Strain & Kalimo et al. (2002) & $\begin{array}{l}\text { SoC protects workers from strain and } \\
\text { thus maintains well-being }\end{array}$ \\
\hline Stress symptoms & Albertsen et al. (2001) & $\begin{array}{l}\text { - } \\
\text { Those with higher SoC experience } \\
\text { fewer stress symptoms } \\
\text { Mediating effect of SoC was supported } \\
\text { Moderating effect of SoC was found, } \\
\text { suggesting that people with higher SoC } \\
\text { coped better with work environmental } \\
\text { strain than those w/ lower SoC } \\
\text { * SoC in part explained association } \\
\text { between work environment and stress } \\
\text { symptoms }\end{array}$ \\
\hline
\end{tabular}




\begin{tabular}{|c|c|c|}
\hline Vigor & Urakawa et al. (2012) & $\begin{array}{l}+ \\
\text { SoC was positively associated with } \\
\text { vigor in both males and females } \\
\text { *Conclusions: Having a strong SoC } \\
\text { may reduce worker's negative job stress } \\
\text { responses and increase their vigor }\end{array}$ \\
\hline $\begin{array}{l}\text { Well-being (overall } \\
\text { and occupational) }\end{array}$ & Feldt et al. (2000) & $\begin{array}{l}+ \\
\text { Strong SoC related to high general and } \\
\text { occupational well-being } \\
\text { Mediator - SoC mediates psychosomatic } \\
\text { symptoms in employees in } \\
\text { organizations with a poor climate } \\
\text { Predictor - SoC level predicted less } \\
\text { psychosomatic symptoms and emotional } \\
\text { exhaustion after a year } \\
\text { Stability - found moderate stability over } \\
\text { 12-month period }\end{array}$ \\
\hline Well-being at work & Feldt (1997) & $\begin{array}{l}+ \\
\text { The stronger the SoC, the lower the } \\
\text { level of psychosomatic symptoms and } \\
\text { emotional exhaustion } \\
\text { SoC moderated the relationship between } \\
\text { perceived work characteristics and well- } \\
\text { being } \\
\text { Strong SoC subjects seem to be better } \\
\text { protected from the adverse effects of } \\
\text { certain work characteristics (e.g., } \\
\text { pressure of time) } \\
\text { Good social relations at work } \\
\text { emphasized well-being in people with a } \\
\text { weak SoC (and less so in people with a } \\
\text { stronger SoC) }\end{array}$ \\
\hline $\begin{array}{l}\text { Work } \\
\text { characteristics }\end{array}$ & Feldt et al. (2004) & $\begin{array}{l}+ \\
\text { SoC at } \mathrm{T} 1 \text { predicted work } \\
\text { characteristics at } \mathrm{T} 2 \\
\text { High SoC predicts good organizational } \\
\text { climate (over } 3 \text {-year follow-up) }\end{array}$ \\
\hline $\begin{array}{l}\text { Work } \\
\text { characteristics }\end{array}$ & $\begin{array}{l}\text { Toppinen-Tanner \& Kalimo } \\
\text { (2003) }\end{array}$ & $\begin{array}{l}\text { SoC moderated the relation of } \\
\text { autonomy to competence and } \\
\text { psychological symptoms (but more } \\
\text { strongly among designers and assisting } \\
\text { personnel than among top-level } \\
\text { designers } \\
\text { Autonomy was beneficial for those with } \\
\text { high SoC }\end{array}$ \\
\hline
\end{tabular}




\begin{tabular}{|c|c|c|}
\hline Work stress & Feldt (1997) & - \\
\hline Work stress & Ryland \& Greenfeld (1991) & - \\
\hline Work violence & Hogh \& Mikkelsen (2005) & $\begin{array}{l}\text { - } \\
\text { Employees subjected to violence have a } \\
\text { weaker SoC } \\
\text { SoC is a mediator (and not a moderator) } \\
\text { of relationships between exposure to } \\
\text { violence and psychological, } \\
\text { psychosomatic, cognitive stress } \\
\text { reactions }\end{array}$ \\
\hline Work wellness & Fourie (2008) & $\begin{array}{l}+ \\
\text { SoC positively predicts work wellness } \\
\text { (low burnout and high work } \\
\text { engagement) } \\
\text { Stronger SoC led to more work wellness } \\
\text { than a weaker SoC }\end{array}$ \\
\hline Work wellness & Rothmann (2005) & $\begin{array}{l}\text { A strong SoC mediated relationship } \\
\text { between job stress and work wellness } \\
\text { (low burnout and high work } \\
\text { engagement) }\end{array}$ \\
\hline $\begin{array}{l}\text { Workplace } \\
\text { incidents/accidents }\end{array}$ & Kotze et al. (2013) & $\begin{array}{l}\text { SoC level negatively associated with } \\
\text { involvement in workplace } \\
\text { incidents/accidents }\end{array}$ \\
\hline $\begin{array}{l}\text { Work-related } \\
\text { conflict }\end{array}$ & Albertsen et al. (2001) & $\begin{array}{l}\text { Mediator - SoC is partial mediator of } \\
\text { relationships between work-related } \\
\text { conflicts and various stress } \\
\text { symptoms/reactions } \\
\text { Moderator (some support) - higher SoC } \\
=\text { better coping with work environment } \\
\text { strain } \\
\text { Association negative - high SoC and } \\
\text { number of stress symptoms }\end{array}$ \\
\hline $\begin{array}{l}\text { Work-related } \\
\text { stress }\end{array}$ & Albertsen et al. (2001) & $\begin{array}{l}\text { High SoC negatively related to number } \\
\text { of stress symptoms }\end{array}$ \\
\hline
\end{tabular}




\section{APPENDIX C}

IRB APPROVAL LETTER 
TO:

FROM: Lindsay Pardue, Director of Research Integrity Dr. Amy Doolittle, IRB Committee Chair

DATE: $11 / 1 / 2016$

SUBJECT: $\quad$ IRB \#16-157: The role of sense of coherence in stressor appraisal

The IRB Committee Chair has reviewed and approved your application and assigned you the IRB number listed above. You must include the following approval statement on research materials seen by participants and used in research reports:

The Institutional Review Board of the University of Tennessee at Chattanooga (FWA00004149) has approved this research project \# 16-157.

Since your project has been deemed exempt, there is no further action needed on this proposal unless there is a significant change in the project that would require a new review. Changes that affect risk to human subjects would necessitate a new application to the IRB committee immediately.

Please remember to contact the IRB Committee immediately and submit a new project proposal for review if significant changes occur in your research design or in any instruments used in conducting the study. You should also contact the IRB Committee immediately if you encounter any adverse effects during your project that pose a risk to your subjects.

For any additional information, please consult our web page http://www.utc.edu/irb or email instrb@utc.edu

Best wishes for a successful research project. 
APPENDIX D

INFORMED CONSENT FORM 


\section{Informed Consent Form}

\section{Purpose of the Study:}

This study is being conducted by Lisa Brady, a graduate student in the Industrial and Organizational Psychology program at The University of Tennessee at Chattanooga. This research is being conducted under the supervision of Dr. Chris Cunningham. The purpose is to examine the role of individual differences in appraising work-related stressors.

\section{What will be done:}

If you agree to participate you will be asked to respond to a brief internet-based survey (requiring approximately 25 minutes of your time). This survey includes questions about your appraisal of common work-related stressors and your sense of coherence. Several demographic questions are also included so that the characteristics of the final sample can be accurately described.

\section{Benefits of this Study:}

You will be contributing to a growing base of knowledge regarding the role of an individual difference in the appraisal of common work-related stressors.

\section{What are the risks to me?}

The risks of this study are anticipated to be limited to the potential inconvenience of taking the survey. If you feel uncomfortable with a question in the survey, you can withdraw from the study at any time. If you decide to quit at any time before you have finished the questionnaire, your answers will NOT be recorded. Please note, however, that we can only make use of fully complete surveys, so we greatly appreciate your full participation and cooperation.

\section{What about my privacy?}

You are able to participate in this study confidentially; no names or personal contact information will be requested from you. In addition to this protection, all data will be securely gathered and stored in password protected files accessible only by the researchers.

\section{Voluntary participation:}

It is your choice to participate in this research and you may withdraw from this study at any time. If you decide to quit any time before you have finished the questionnaire, however, your answers will NOT be recorded. We can only make use of fully complete surveys, so we greatly appreciate your full participation.

\section{How will the data be used?}

The results of the study will be used for research purposes only. Group-level (not personally identified) results from the study will be presented in educational settings and at professional conferences, and the results may be published in a professional journal in the field of psychology.

\section{Contact information:}

If you have concerns or questions about this study, please contact the chair of UTC's Institutional Review Board, Dr. Amy Doolittle, at amy-doolittle@utc.edu or 423-425-5563 or the 
faculty supervisor for this study, Dr. Christopher Cunningham, at chris-cunningham@utc.edu or 423-425-4264. By completing and returning this survey, you acknowledge that you have read this information and agree to participate in this research, with the knowledge that you are free to withdraw your participation at any time without penalty.

Thank you in advance for your assistance and participation.

Sincerely,

Lisa Brady

Christopher J. L. Cunningham, Ph.D.

The University of Tennessee Chattanooga

The Institutional Review Board of the University of Tennessee at Chattanooga (FWA00004149) has approved this research project \# ******

I have reviewed the information above and am willing to participate in this survey.

Yes No 


\section{Inclusion/Exclusion Criteria}

Are you currently enrolled as a full-time graduate student with additional responsibilities (e.g., Graduate/Research/Teaching Assistantship, part-/full-time work, etc.) Yes

No

Are you currently a full-time employee (working at least 34 hours per week)?

Yes

No 
APPENDIX E

MEASURES 


\section{Orientation to Life Questionnaire (OLQ) (SoC-29)}

Please respond to the following statements.

\begin{tabular}{|c|c|c|}
\hline C1r & $\begin{array}{l}\text { When you talk to people, do you } \\
\text { have the feeling that they don't } \\
\text { understand you? (C) } \mathbf{R}\end{array}$ & $\begin{array}{l}1=\text { Never } \\
2= \\
3= \\
4= \\
5= \\
6= \\
7=\text { Always }\end{array}$ \\
\hline Ma1 & $\begin{array}{l}\text { In the past, when you had to do } \\
\text { something which depended upon } \\
\text { cooperation with others, did you } \\
\text { have the feeling that it: (Ma) }\end{array}$ & $\begin{array}{l}1=\text { Surely would not get done } \\
2= \\
3= \\
4= \\
5= \\
6= \\
7=\text { Surely would get done }\end{array}$ \\
\hline $\mathrm{C} 2$ & $\begin{array}{l}\text { Think of the people with whom } \\
\text { you come into contact daily, } \\
\text { aside from the ones to whom you } \\
\text { feel closest. How well do you } \\
\text { know most of them? (C) }\end{array}$ & $\begin{array}{l}1=\text { You feel that they are strangers } \\
2= \\
3= \\
4= \\
5= \\
6= \\
7=\text { You feel that you know them very well }\end{array}$ \\
\hline Me1r & $\begin{array}{l}\text { Do you have the feeling that you } \\
\text { don't really care about what goes } \\
\text { on around you? (Me) } \mathbf{R}\end{array}$ & $\begin{array}{l}1=\text { Very seldom or never } \\
2= \\
3= \\
4= \\
5= \\
6= \\
7=\text { Very often }\end{array}$ \\
\hline C3r & $\begin{array}{l}\text { Has it happened in the past that } \\
\text { you were surprised by the } \\
\text { behavior of people whom you } \\
\text { thought you knew well? (C) } \mathbf{R}\end{array}$ & $\begin{array}{l}1=\text { Never happened } \\
2= \\
3= \\
4= \\
5= \\
6= \\
7=\text { Always happened }\end{array}$ \\
\hline $\mathrm{Ma} 2 \mathrm{r}$ & $\begin{array}{l}\text { Has it happened that people } \\
\text { whom you counted on } \\
\text { disappointed you? (Ma) } \mathbf{R}\end{array}$ & $\begin{array}{l}1=\text { Never happened } \\
2= \\
3= \\
4= \\
5= \\
6=\end{array}$ \\
\hline
\end{tabular}




\begin{tabular}{|c|c|c|}
\hline & & $7=$ Always happened \\
\hline $\mathrm{Me} 2 \mathrm{r}$ & Life is: $(\mathrm{Me}) \mathbf{R}$ & $\begin{array}{l}1=\text { Full of interest } \\
2= \\
3= \\
4= \\
5= \\
6= \\
7=\text { Completely routine }\end{array}$ \\
\hline $\mathrm{Me} 3$ & Until now your life has had: $(\mathrm{Me})$ & $\begin{array}{l}1=\text { No clear goals or purpose at all } \\
2= \\
3= \\
4= \\
5= \\
6= \\
7=\text { Very clear goals and purpose }\end{array}$ \\
\hline Ma3 & $\begin{array}{l}\text { Do you have the feeling that } \\
\text { you're being treated unfairly? } \\
\text { (Ma) }\end{array}$ & $\begin{array}{l}1=\text { Very often } \\
2= \\
3= \\
4= \\
5= \\
6= \\
7=\text { Seldom or never }\end{array}$ \\
\hline $\mathrm{C} 4$ & $\begin{array}{l}\text { In the past ten years your life has } \\
\text { been: (C) }\end{array}$ & $\begin{array}{l}1=\text { Full of changes } \\
2= \\
3= \\
4= \\
5= \\
6= \\
7=\text { Completely consistent and clear without you } \\
\text { knowing what will happen next }\end{array}$ \\
\hline $\mathrm{Me} 4 \mathrm{r}$ & $\begin{array}{l}\text { Most of the things you do in the } \\
\text { future will probably be: (Me) } \mathbf{R}\end{array}$ & $\begin{array}{l}1=\text { Completely fascinating } \\
2= \\
3= \\
4= \\
5= \\
6= \\
7=\text { Completely boring }\end{array}$ \\
\hline $\mathrm{C} 5$ & $\begin{array}{l}\text { Do you have the feeling that you } \\
\text { are in an unfamiliar situation and } \\
\text { don't know what to do? (C) }\end{array}$ & $\begin{array}{l}1=\text { Very often } \\
2= \\
3= \\
4= \\
5= \\
6= \\
7=\text { Very seldom or never }\end{array}$ \\
\hline
\end{tabular}




\begin{tabular}{|c|c|c|}
\hline $\mathrm{Ma} 4 \mathrm{r}$ & $\begin{array}{l}\text { What best describes how you see } \\
\text { life: (Ma) R }\end{array}$ & $\begin{array}{l}1=\text { One can always find a solution to painful } \\
\text { things in life } \\
2= \\
3= \\
4= \\
5= \\
6= \\
7=\text { There is no solution to painful things in life }\end{array}$ \\
\hline Me5r & $\begin{array}{l}\text { When you think about your life, } \\
\text { you very often: }(\mathrm{Me}) \mathbf{R}\end{array}$ & $\begin{array}{l}1=\text { Feel how good it is to be alive } \\
2= \\
3= \\
4= \\
5= \\
6= \\
7=\text { Ask yourself why you exist at all }\end{array}$ \\
\hline C6 & $\begin{array}{l}\text { When you face a difficult } \\
\text { problem, the choice of a solution } \\
\text { is: (C) }\end{array}$ & $\begin{array}{l}1=\text { Always confusing and hard to find } \\
2= \\
3= \\
4= \\
5= \\
6= \\
7=\text { Always completely clear }\end{array}$ \\
\hline Me6r & $\begin{array}{l}\text { Doing the things you do every } \\
\text { day is: }(\mathrm{Me}) \mathbf{R}\end{array}$ & $\begin{array}{l}1=\text { A source of deep pleasure and satisfaction } \\
2= \\
3= \\
4= \\
5= \\
6= \\
7=\text { A source of pain and boredom }\end{array}$ \\
\hline C7 & $\begin{array}{l}\text { Your life in the future will } \\
\text { probably be: (C) }\end{array}$ & $\begin{array}{l}1=\text { Full of changes without knowing what will } \\
\text { happen next } \\
2= \\
3= \\
4= \\
5= \\
6= \\
7=\text { Completely consistent and clear }\end{array}$ \\
\hline Ma5 & $\begin{array}{l}\text { When something unpleasant } \\
\text { happened in the past your } \\
\text { tendency was: (Ma) }\end{array}$ & $\begin{array}{l}1=\text { "To eat yourself up" about it } \\
2= \\
3= \\
4= \\
5= \\
6= \\
7=\text { To say "ok that's that, I have to live with it" } \\
\text { and go on }\end{array}$ \\
\hline
\end{tabular}




\begin{tabular}{|c|c|c|}
\hline C8 & $\begin{array}{l}\text { Do you have very mixed-up } \\
\text { feelings and ideas? (C) }\end{array}$ & $\begin{array}{l}1=\text { Very often } \\
2= \\
3= \\
4= \\
5= \\
6= \\
7=\text { Seldom or never }\end{array}$ \\
\hline Ma6r & $\begin{array}{l}\text { When you do something that } \\
\text { gives you a good feeling: (Ma) } \mathbf{R}\end{array}$ & $\begin{array}{l}1=\text { It's certain that you'll go on feeling good } \\
2= \\
3= \\
4= \\
5= \\
6= \\
7=\text { It's certain that something will happen to } \\
\text { spoil the feeling }\end{array}$ \\
\hline C9 & $\begin{array}{l}\text { Does it happen that you have } \\
\text { feelings inside you would rather } \\
\text { not feel? (C) }\end{array}$ & $\begin{array}{l}1=\text { Very often } \\
2= \\
3= \\
4= \\
5= \\
6= \\
7=\text { Very seldom or never }\end{array}$ \\
\hline $\mathrm{Me} 7$ & $\begin{array}{l}\text { You anticipate that your personal } \\
\text { life in the future will be: (Me) }\end{array}$ & $\begin{array}{l}1=\text { Totally without meaning or purpose } \\
2= \\
3= \\
4= \\
5= \\
6= \\
7=\text { Full of meaning and purpose }\end{array}$ \\
\hline Ma7r & $\begin{array}{l}\text { Do you think that there will } \\
\text { always be people whom you'll be } \\
\text { able to count on in the future? } \\
\text { (Ma) } \mathbf{R}\end{array}$ & $\begin{array}{l}1=\text { You are certain there will be } \\
2= \\
3= \\
4= \\
5= \\
6= \\
7=\text { You doubt there will be }\end{array}$ \\
\hline C10 & $\begin{array}{l}\text { Does it happen that you have the } \\
\text { feeling that you don't know } \\
\text { exactly what's about to happen? } \\
\text { (C) }\end{array}$ & $\begin{array}{l}1=\text { Very often } \\
2= \\
3= \\
4= \\
5= \\
6= \\
7=\text { Very seldom or never }\end{array}$ \\
\hline $\mathrm{Ma} 8 \mathrm{r}$ & $\begin{array}{l}\text { Many people }- \text { even those with a } \\
\text { strong character - sometimes feel }\end{array}$ & $\begin{array}{l}1=\text { Never } \\
2=\end{array}$ \\
\hline
\end{tabular}




\begin{tabular}{|c|c|c|}
\hline & $\begin{array}{l}\text { like sad sacks (losers) in certain } \\
\text { situations. How often have you } \\
\text { felt this way in the past? (Ma) } \mathbf{R}\end{array}$ & $\begin{array}{l}3= \\
4= \\
5= \\
6= \\
7=\text { Very often }\end{array}$ \\
\hline C11 & $\begin{array}{l}\text { When something happened, have } \\
\text { you generally found that: }(C)\end{array}$ & $\begin{array}{l}1=\text { You overestimated or underestimated its } \\
\text { importance } \\
2= \\
3= \\
4= \\
5= \\
6= \\
7=\text { You saw things in the right proportion }\end{array}$ \\
\hline Ma9r & $\begin{array}{l}\text { When you think of the } \\
\text { difficulties you are likely to face } \\
\text { in important aspects of your life, } \\
\text { do you have the feeling that: } \\
\text { (Ma) } \mathbf{R}\end{array}$ & $\begin{array}{l}1=\text { You will always succeed in overcoming the } \\
\text { difficulties } \\
2= \\
3= \\
4= \\
5= \\
6= \\
7=\text { You won't succeed in overcoming the } \\
\text { difficulties }\end{array}$ \\
\hline $\mathrm{Me} 8$ & $\begin{array}{l}\text { How often do you have the } \\
\text { feeling that there's little meaning } \\
\text { in the things you do in your daily } \\
\text { life? (Me) }\end{array}$ & $\begin{array}{l}1=\text { Very often } \\
2= \\
3= \\
4= \\
5= \\
6= \\
7=\text { Very seldom or never }\end{array}$ \\
\hline Ma10 & $\begin{array}{l}\text { How often do you have feelings } \\
\text { that you're not sure you can keep } \\
\text { under control? (Ma) }\end{array}$ & $\begin{array}{l}1=\text { Very often } \\
2= \\
3= \\
4= \\
5= \\
6= \\
7=\text { Very seldom or never }\end{array}$ \\
\hline
\end{tabular}

Scoring instructions:

(C) = comprehensibility component

$(\mathrm{Ma})=$ manageability component

$(\mathrm{Me})=$ meaningful component

$\mathbf{R}=$ reverse scored 


\section{Work-related Sense of Coherence}

\begin{tabular}{|c|c|c|c|c|c|c|c|c|c|}
\hline \multicolumn{10}{|c|}{ How do you personally find your current job and work situation in general? } \\
\hline $1 r$ & manageable & o & ○ & 0 & 0 & O & ○ & O & unmanageable \\
\hline 2 & meaningless & ○ & ○ & O & ○ & o & o & o & meaningful \\
\hline $3 r$ & structured & 0 & 0 & 0 & 0 & 0 & 0 & 0 & unstructured \\
\hline $4 r$ & $\begin{array}{l}\text { easy to } \\
\text { influence }\end{array}$ & o & o & 0 & 0 & o & o & o & $\begin{array}{l}\text { impossible to } \\
\text { influence }\end{array}$ \\
\hline 5 & insignificant & 0 & 0 & 0 & 0 & 0 & o & o & significant \\
\hline $6 r$ & clear & 0 & o & 0 & 0 & o & o & o & unclear \\
\hline $7 r$ & controllable & 0 & 0 & 0 & 0 & 0 & 0 & 0 & uncontrollable \\
\hline 8 & unrewarding & o & o & 0 & 0 & o & o & o & rewarding \\
\hline $9 r$ & predictable & 0 & 0 & 0 & 0 & 0 & 0 & o & unpredictable \\
\hline
\end{tabular}

Comprehensibility: Items 1, 3, 6 and 9

Manageability: Items 4 and 7

Meaningfulness: Items 2, 5, and 8 


\section{Stress in General}

Do you find your job stressful? For each of the following words or phrases below select:

$Y$ for "Yes" if it describes your job;

$\mathrm{N}$ for "No" if it does not describe your job;

? for "?" if you cannot decide.

\begin{tabular}{|l|l|}
\hline Demanding & Yes \\
& No \\
& $?$ \\
\hline Pressured & Yes \\
& No \\
& $?$ \\
\hline Calm (R) & Yes \\
& No \\
& $?$ \\
\hline Many things stressful & Yes \\
& No \\
& $?$ \\
\hline Hassled & Yes \\
& No \\
& $?$ \\
\hline Nerve-racking & Yes \\
& No \\
\hline More stressful than I'd like & $?$ \\
\hline Overwhelming & Yes \\
& No \\
& $?$ \\
\hline & Yes \\
& No \\
& $?$ \\
\hline & \\
\hline
\end{tabular}




\section{General Appraisal of Work-Related Stressors}

The "work environment" includes your environment as an employee of an organization and/or your environment as a student (including any time spent in class, studying or doing homework, or working for pay outside of class).

A "stressor" represents a situation or events in the work environment that requires some adaptive response on the part of the individual (Jex \& Britt, 2014). For example: a difficult coworker, a work interruption, a new management style, or a project deadline.

Instructions: Think about your current work environment. Please now assess how encountering "stressors" (as defined above) is likely to affect you.

\begin{tabular}{|c|c|}
\hline They will help me to learn a lot. & $\begin{array}{l}1=\text { Disagree strongly } \\
2=\text { Disagree moderately } \\
3=\text { Disagree } \\
4=\text { Neither agree nor disagree } \\
5=\text { Agree } \\
6=\text { Agree moderately } \\
7=\text { Agree strongly }\end{array}$ \\
\hline They will help me develop my skills. & $\begin{array}{l}1=\text { Disagree strongly } \\
2=\text { Disagree moderately } \\
3=\text { Disagree } \\
4=\text { Neither agree nor disagree } \\
5=\text { Agree } \\
6=\text { Agree moderately } \\
7=\text { Agree strongly }\end{array}$ \\
\hline They will show me I can do something new. & $\begin{array}{l}1=\text { Disagree strongly } \\
2=\text { Disagree moderately } \\
3=\text { Disagree } \\
4=\text { Neither agree nor disagree } \\
5=\text { Agree } \\
6=\text { Agree moderately } \\
7=\text { Agree strongly }\end{array}$ \\
\hline They will keep me focused on doing well. & $\begin{array}{l}1=\text { Disagree strongly } \\
2=\text { Disagree moderately } \\
3=\text { Disagree } \\
4=\text { Neither agree nor disagree } \\
5=\text { Agree } \\
6=\text { Agree moderately } \\
7=\text { Agree strongly }\end{array}$ \\
\hline $\begin{array}{l}\text { They will hinder any achievements I might } \\
\text { have. }\end{array}$ & $\begin{array}{l}1=\text { Disagree strongly } \\
2=\text { Disagree moderately } \\
3=\text { Disagree } \\
4=\text { Neither agree nor disagree }\end{array}$ \\
\hline
\end{tabular}




\begin{tabular}{|c|c|}
\hline & $\begin{array}{l}5=\text { Agree } \\
6=\text { Agree moderately } \\
7=\text { Agree strongly }\end{array}$ \\
\hline They will restrict my capabilities. & $\begin{array}{l}1=\text { Disagree strongly } \\
2=\text { Disagree moderately } \\
3=\text { Disagree } \\
4=\text { Neither agree nor disagree } \\
5=\text { Agree } \\
6=\text { Agree moderately } \\
7=\text { Agree strongly }\end{array}$ \\
\hline They will limit how well I can do. & $\begin{array}{l}1=\text { Disagree strongly } \\
2=\text { Disagree moderately } \\
3=\text { Disagree } \\
4=\text { Neither agree nor disagree } \\
5=\text { Agree } \\
6=\text { Agree moderately } \\
7=\text { Agree strongly }\end{array}$ \\
\hline $\begin{array}{l}\text { They will prevent me from mastering } \\
\text { difficult aspects of the work. }\end{array}$ & $\begin{array}{l}1=\text { Disagree strongly } \\
2=\text { Disagree moderately } \\
3=\text { Disagree } \\
4=\text { Neither agree nor disagree } \\
5=\text { Agree } \\
6=\text { Agree moderately } \\
7=\text { Agree strongly }\end{array}$ \\
\hline They may be a negative experience for me. & $\begin{array}{l}1=\text { Disagree strongly } \\
2=\text { Disagree moderately } \\
3=\text { Disagree } \\
4=\text { Neither agree nor disagree } \\
5=\text { Agree } \\
6=\text { Agree moderately } \\
7=\text { Agree strongly }\end{array}$ \\
\hline They will result in negative outcomes. & $\begin{array}{l}1=\text { Disagree strongly } \\
2=\text { Disagree moderately } \\
3=\text { Disagree } \\
4=\text { Neither agree nor disagree } \\
5=\text { Agree } \\
6=\text { Agree moderately } \\
7=\text { Agree strongly }\end{array}$ \\
\hline $\begin{array}{l}\text { They are going to have a negative impact } \\
\text { on me. }\end{array}$ & $\begin{array}{l}1=\text { Disagree strongly } \\
2=\text { Disagree moderately } \\
3=\text { Disagree } \\
4=\text { Neither agree nor disagree } \\
5=\text { Agree } \\
6=\text { Agree moderately } \\
7=\text { Agree strongly }\end{array}$ \\
\hline
\end{tabular}




\section{Prevalence of Specific Work-Related Stressors}

The "work environment" includes your environment as an employee of an organization and/or your environment as a student (including any time spent in class, studying or doing homework, or working for pay outside of class).

Instructions: Please rate the extent to which each of the following statements is true concerning your current "work environment".

\begin{tabular}{|c|c|}
\hline Work-related characteristic & $\begin{array}{l}\text { Rate the extent to which each } \\
\text { statement is true in your } \\
\text { current work environment. }\end{array}$ \\
\hline $\begin{array}{l}\text { Job autonomy } \\
\text { I have discretion in planning out my work and } \\
\text { determining procedures in my work. }\end{array}$ & $\begin{array}{l}1=\text { Not at all } \\
2=\text { A little } \\
3=\text { Somewhat } \\
4=\text { Moderately } \\
5=\text { Quite a bit } \\
6=\text { Very } \\
7=\text { Completely }\end{array}$ \\
\hline $\begin{array}{l}\text { Participative decision-making } \\
\text { I have input in the formulation of decisions that I am } \\
\text { responsible for implementing. }\end{array}$ & $\begin{array}{l}1=\text { Not at all } \\
2=\text { A little } \\
3=\text { Somewhat } \\
4=\text { Moderately } \\
5=\text { Quite a bit } \\
6=\text { Very } \\
7=\text { Completely }\end{array}$ \\
\hline $\begin{array}{l}\text { Predictability of work } \\
\text { I experience unexpected events in my work. }\end{array}$ & $\begin{array}{l}1=\text { Not at all } \\
2=\text { A little } \\
3=\text { Somewhat } \\
4=\text { Moderately } \\
5=\text { Quite a bit } \\
6=\text { Very } \\
7=\text { Completely }\end{array}$ \\
\hline $\begin{array}{l}\text { Role ambiguity } \\
\text { I receive unclear information concerning my work } \\
\text { objectives and what is expected of me. }\end{array}$ & $\begin{array}{l}1=\text { Not at all } \\
2=\text { A little } \\
3=\text { Somewhat } \\
4=\text { Moderately } \\
5=\text { Quite a bit } \\
6=\text { Very } \\
7=\text { Completely }\end{array}$ \\
\hline $\begin{array}{l}\text { Role conflict } \\
\text { I receive conflicting information or inconsistent } \\
\text { demands concerning my work or work methods. }\end{array}$ & $\begin{array}{l}1=\text { Not at all } \\
2=\text { A little } \\
3=\text { Somewhat } \\
4=\text { Moderately } \\
5=\text { Quite a bit }\end{array}$ \\
\hline
\end{tabular}




\begin{tabular}{|c|c|}
\hline & $\begin{array}{l}6=\text { Very } \\
7=\text { Completely }\end{array}$ \\
\hline $\begin{array}{l}\text { Quantitative work overload } \\
\text { I have too much work to do within a given time frame. }\end{array}$ & $\begin{array}{l}1=\text { Not at all } \\
2=\text { A little } \\
3=\text { Somewhat } \\
4=\text { Moderately } \\
5=\text { Quite a bit } \\
6=\text { Very } \\
7=\text { Completely }\end{array}$ \\
\hline$\frac{\text { Qualitative work overload }}{\text { My work is too difficult and exceeds my abilities. }}$ & $\begin{array}{l}1=\text { Not at all } \\
2=\text { A little } \\
3=\text { Somewhat } \\
4=\text { Moderately } \\
5=\text { Quite a bit } \\
6=\text { Very } \\
7=\text { Completely }\end{array}$ \\
\hline$\frac{\text { Quantitative work underload }}{\text { I do not have enough work to do. }}$ & $\begin{array}{l}1=\text { Not at all } \\
2=\text { A little } \\
3=\text { Somewhat } \\
4=\text { Moderately } \\
5=\text { Quite a bit } \\
6=\text { Very } \\
7=\text { Completely }\end{array}$ \\
\hline $\begin{array}{l}\text { Qualitative work underload } \\
\text { My work is too simple and does not allow me to use my } \\
\text { full abilities. }\end{array}$ & $\begin{array}{l}1=\text { Not at all } \\
2=\text { A little } \\
3=\text { Somewhat } \\
4=\text { Moderately } \\
5=\text { Quite a bit } \\
6=\text { Very } \\
7=\text { Completely }\end{array}$ \\
\hline $\begin{array}{l}\text { Responsibility for others } \\
\text { I am responsible for the work of others (e.g., others' } \\
\text { morale, division of labor). }\end{array}$ & $\begin{array}{l}1=\text { Not at all } \\
2=\text { A little } \\
3=\text { Somewhat } \\
4=\text { Moderately } \\
5=\text { Quite a bit } \\
6=\text { Very } \\
7=\text { Completely }\end{array}$ \\
\hline $\begin{array}{l}\text { Lack of social support from colleagues } \\
\text { There is a lack of help and support from my colleagues. }\end{array}$ & $\begin{array}{l}1=\text { Not at all } \\
2=\text { A little } \\
3=\text { Somewhat } \\
4=\text { Moderately } \\
5=\text { Quite a bit } \\
6=\text { Very } \\
7=\text { Completely }\end{array}$ \\
\hline Lack of social support from supervisors & $1=$ Not at all \\
\hline
\end{tabular}




\begin{tabular}{|c|c|}
\hline $\begin{array}{l}\text { There is a lack of help and support from my } \\
\text { supervisors. }\end{array}$ & $\begin{array}{l}2=\text { A little } \\
3=\text { Somewhat } \\
4=\text { Moderately } \\
5=\text { Quite a bit } \\
6=\text { Very } \\
7=\text { Completely }\end{array}$ \\
\hline $\begin{array}{l}\text { Interpersonal conflict among colleagues or peers } \\
\text { My work environment consists of negatively charged } \\
\text { interactions between colleagues and peers in the work } \\
\text { environment. }\end{array}$ & $\begin{array}{l}1=\text { Not at all } \\
2=\text { A little } \\
3=\text { Somewhat } \\
4=\text { Moderately } \\
5=\text { Quite a bit } \\
6=\text { Very } \\
7=\text { Completely }\end{array}$ \\
\hline $\begin{array}{l}\text { Interpersonal conflict among involving one's supervisor } \\
\text { My work environment consists of negatively charged } \\
\text { interactions involving my supervisor. }\end{array}$ & $\begin{array}{l}1=\text { Not at all } \\
2=\text { A little } \\
3=\text { Somewhat } \\
4=\text { Moderately } \\
5=\text { Quite a bit } \\
6=\text { Very } \\
7=\text { Completely }\end{array}$ \\
\hline $\begin{array}{l}\text { Bureaucratic constraints } \\
\text { The company bureaucracy (e.g., rules and procedures) } \\
\text { at my organization prevent me from performing up to } \\
\text { my capabilities. }\end{array}$ & $\begin{array}{l}1=\text { Not at all } \\
2=\text { A little } \\
3=\text { Somewhat } \\
4=\text { Moderately } \\
5=\text { Quite a bit } \\
6=\text { Very } \\
7=\text { Completely }\end{array}$ \\
\hline $\begin{array}{l}\text { Material and technological constraints } \\
\text { The missing and/or lack of equipment and supplies at } \\
\text { work prevents me from performing up to my } \\
\text { capabilities. }\end{array}$ & $\begin{array}{l}1=\text { Not at all } \\
2=\text { A little } \\
3=\text { Somewhat } \\
4=\text { Moderately } \\
5=\text { Quite a bit } \\
6=\text { Very } \\
7=\text { Completely }\end{array}$ \\
\hline $\begin{array}{l}\text { Job insecurity } \\
\text { I am uncertain about the security of my job in the } \\
\text { future. }\end{array}$ & $\begin{array}{l}1=\text { Not at all } \\
2=\text { A little } \\
3=\text { Somewhat } \\
4=\text { Moderately } \\
5=\text { Quite a bit } \\
6=\text { Very } \\
7=\text { Completely }\end{array}$ \\
\hline
\end{tabular}




\section{Appraisal of Specific Work-Related Stressors}

The "work environment" includes your environment as an employee of an organization and/or your environment as a student (including any time spent in class, studying or doing homework, or working for pay outside of class).

Instructions: Please report the extent to which you encountering each of the following work-related characteristics in your current work environment affects you.

\begin{tabular}{|c|c|c|c|}
\hline Work-related characteristic & $\begin{array}{l}\text { To what extent } \\
\text { does } \\
\text { encountering } \\
\text { this have } \\
\text { potentially } \\
\text { meaningful } \\
\text { gains for you? }\end{array}$ & $\begin{array}{l}\text { To what extent } \\
\text { does } \\
\text { encountering } \\
\text { this tend to } \\
\text { constrain or } \\
\text { interfere with } \\
\text { your individual } \\
\text { work } \\
\text { achievement? }\end{array}$ & $\begin{array}{l}\text { To what extent } \\
\text { does } \\
\text { encountering } \\
\text { this post a } \\
\text { threat to you? }\end{array}$ \\
\hline $\begin{array}{l}\text { Job autonomy } \\
\text { I have discretion in planning out } \\
\text { my work and determining } \\
\text { procedures in my work. }\end{array}$ & $1<--->100$ & $1<--->100$ & $1<--->100$ \\
\hline $\begin{array}{l}\text { Participative decision-making } \\
\text { I have input in the formulation } \\
\text { of decisions that I am } \\
\text { responsible for implementing. }\end{array}$ & $1<--->100$ & $1<--->100$ & $1<--->100$ \\
\hline $\begin{array}{l}\text { Predictability of work } \\
\text { I experience unexpected events } \\
\text { in my work. }\end{array}$ & $1<--->100$ & $1<--->100$ & $1<--->100$ \\
\hline $\begin{array}{l}\text { Role ambiguity } \\
\text { I receive unclear information } \\
\text { concerning my work objectives } \\
\text { and what is expected of me. }\end{array}$ & $1<--->100$ & $1<--->100$ & $1<--->100$ \\
\hline $\begin{array}{l}\text { Role conflict } \\
\text { I receive conflicting information } \\
\text { or inconsistent demands } \\
\text { concerning my work or work } \\
\text { methods. }\end{array}$ & $1<---->100$ & $1<---->100$ & $1<---->100$ \\
\hline $\begin{array}{l}\text { Quantitative work overload } \\
\text { I have too much work to do } \\
\text { within a given time frame. }\end{array}$ & $1<--->100$ & $1<--->100$ & $1<--->100$ \\
\hline $\begin{array}{l}\text { Qualitative work overload } \\
\text { My work is too difficult and } \\
\text { exceeds my abilities }\end{array}$ & $1<--->100$ & $1<--->100$ & $1<--->100$ \\
\hline$\frac{\text { Quantitative work underload }}{\text { I do not have enough work to do }}$ & $1<--->100$ & $1<--->100$ & $1<---->100$ \\
\hline
\end{tabular}




\begin{tabular}{|c|c|c|c|}
\hline $\begin{array}{l}\text { Qualitative work underload } \\
\text { My work is too simple and does } \\
\text { not allow me to use my full } \\
\text { abilities. }\end{array}$ & $1<--->100$ & $1<--->100$ & $1<--->100$ \\
\hline $\begin{array}{l}\text { Responsibility for others } \\
\text { I am responsible for the work of } \\
\text { others (e.g., others' morale, } \\
\text { division of labor) }\end{array}$ & $1<--->100$ & $1<--->100$ & $1<--->100$ \\
\hline $\begin{array}{l}\text { Lack of social support from } \\
\text { colleagues } \\
\text { There is a lack of help and } \\
\text { support from my colleagues. }\end{array}$ & $1<--->100$ & $1<--->100$ & $1<--->100$ \\
\hline $\begin{array}{l}\text { Lack of social support from } \\
\text { supervisors } \\
\text { There is a lack of help and } \\
\text { support from my supervisors. }\end{array}$ & $1<---->100$ & $1<--->100$ & $1<--->100$ \\
\hline $\begin{array}{l}\text { Interpersonal conflict among } \\
\text { colleagues or peers } \\
\text { My work environment consists } \\
\text { of negatively charged } \\
\text { interactions between colleagues } \\
\text { and peers in the work } \\
\text { environment. }\end{array}$ & $1<--->100$ & $1<--->100$ & $1<--->100$ \\
\hline $\begin{array}{l}\text { Interpersonal conflict among } \\
\text { involving one's supervisor } \\
\text { My work environment consists } \\
\text { of negatively charged } \\
\text { interactions involving my } \\
\text { supervisor. }\end{array}$ & $1<--->100$ & $1<--->100$ & $1<--->100$ \\
\hline $\begin{array}{l}\text { Bureaucratic constraints } \\
\text { The company bureaucracy (e.g., } \\
\text { rules and procedures) at my } \\
\text { organization prevent me from } \\
\text { performing up to my } \\
\text { capabilities. }\end{array}$ & $1<--->100$ & $1<--->100$ & $1<--->100$ \\
\hline $\begin{array}{l}\text { Material and technological } \\
\text { constraints } \\
\text { The missing and/or lack of } \\
\text { equipment and supplies at work } \\
\text { prevents me from performing } \\
\text { up to my capabilities. }\end{array}$ & $1<--->100$ & $1<--->100$ & $1<--->100$ \\
\hline $\begin{array}{l}\text { Job insecurity } \\
\text { I am uncertain about the } \\
\text { security of my job in the future. }\end{array}$ & $1<--->100$ & $1<--->100$ & $1<--->100$ \\
\hline
\end{tabular}




\section{Demographics}

1. What is your sex?

$$
\begin{aligned}
& 1=\text { Male } \\
& 2=\text { Female }
\end{aligned}
$$

2. What is your current age? (enter only the number, example: 31 )

3. What is your marital status?

1 = Married or living as married

2 = In a committed (serious) relationship but not married

3 = Single, never married

4 = Single, divorced

5 = Single, widowed

4. What is your ethnicity? (select ethnicity with which you most closely identify)

$$
\begin{aligned}
& 1=\text { Hispanic/Latino } \\
& 2=\text { Non-Hispanic/Non-Latino }
\end{aligned}
$$

5. What is your race? (select race with which you most closely identify)

$$
\begin{aligned}
& 1=\text { White } \\
& 2=\text { Black/African American } \\
& 3=\text { Asian } \\
& 4=\text { American Indian/Alaskan Native } \\
& 5=\text { Native Hawaiian/Pacific Islander } \\
& 6=\text { Middle Eastern/Arab }
\end{aligned}
$$

6. What is the highest education level you have received?

$$
\begin{aligned}
& 1=\text { Some high school } \\
& 2=\text { Completed high school } \\
& 3=\text { Some college } \\
& 4=\text { Associate's degree } \\
& 5=\text { Bachelor's degree } \\
& 6=\text { Some graduate school } \\
& 7=\text { Master's degree } \\
& 8=\text { Doctoral degree }
\end{aligned}
$$

7. To how many children are you considered a parent? (report just the number of children, example: 3 )

8. How many children and adults depend on you for their care? (report just the number of children, example: 3 )

9. How many individuals currently reside in your household, including yourself (report just the number of children, example: 3 ) 
10. If you have problems and are sad, is there anyone you can talk to? (You may select more than one option). An index ranging from zero to six will be constructed, depending on how many persons the participant has for potential intimate talk.

$$
\begin{array}{ll}
1 & =\text { Spouse } \\
2 & =\text { Children } \\
3 & =\text { Relative } \\
4 & =\text { Close friend } \\
5 & =\text { Neighbor } \\
6 & =\text { Coworker }
\end{array}
$$

11. Please enter your annual household income. (round to the nearest thousand)

12. Please identify the industry in which you currently work. If the industry is not listed, please identify within the "other" box.

$$
\begin{aligned}
1 & =\text { Manufacturing } \\
2 & =\text { Retail } \\
3 & =\text { Wholesale } \\
4 & =\text { Transportation and Warehousing } \\
5 & =\text { Information } \\
6 & =\text { Financial Activities } \\
7 & =\text { Professional \& Business Services } \\
8 & =\text { Education and Health Services } \\
9 & =\text { Leisure \& Hospitality } \\
10 & =\text { Other: }
\end{aligned}
$$

13. What is your current job title?

14. Enter the average number of hours you work in a week. "Work" refers to any time spent working as an employee of an organization or as a student (including time spent in class, studying or doing homework, or working for pay). If you have multiple "work" roles, add the hours together. (Please round to the nearest amount of hours).

15. How many individuals work directly under your leadership or supervision in your current position?

16. How many years have you been working in your current position? "Work" refers to any time spent working as an employee of an organization or as a student (including time spent in class, studying or doing homework, or working for pay). If you have multiple "work" roles, add the hours together. (Please round to the nearest amount of hours).

17. If you are not in school, how many years have you been working full-time (i.e., at least 34 hours per week)? (round to the nearest year) 


\section{Copy of Actual Survey}

\section{Default Question Block}

\section{INFORMED CONSENT LETTER}

\section{Purpose of the Study:}

This study is being conducted by Lisa Brady, a graduate student in the Industrial and Organizational Psychology program at The University of Tennessee at Chattanooga. This research is being conducted under the supervision of Dr. Chris Cunningham. Please note that participants in this study must be at least 18 years of age. The purpose is to examine the role of individual differences in appraising work-related stressors.

\section{What will be done:}

If you agree to participate you will be asked to respond to a brief internet-based survey (requiring approximately 25 minutes of your time). This survey includes questions about your appraisal of common work-related stressors and your sense of coherence. Several demographic questions are also included so that the characteristics of the final sample can be accurately described.

\section{Benefits of this Study:}

You will be contributing to a growing base of knowledge regarding the role of an individual difference in the appraisal of common work-related stressors.

\section{What are the risks to me?}

The risks of this study are anticipated to be limited to the potential inconvenience of taking the survey. If you feel uncomfortable with a question in the survey, you can withdraw from the study at any time. If you decide to quit at any time before you have finished the questionnaire, your answers will NOT be recorded. Please note, however, that we can only make use of fully complete surveys, so we greatly appreciate your full participation and cooperation. 


\section{What about my privacy?}

You are able to participate in this study confidentially; no names or personal contact information will be requested from you. In addition to this protection, all data will be securely gathered and stored in password protected files accessible only by the researchers.

\section{Voluntary participation:}

It is your choice to participate in this research and you may withdraw from this study at any time. If you decide to quit any time before you have finished the questionnaire, however, your answers will NOT be recorded. We can only make use of fully complete surveys, so we greatly appreciate your full participation.

\section{How will the data be used?}

The results of the study will be used for research purposes only. Group-level (not personally identified) results from the study will be presented in educational settings and at professional conferences, and the results may be published in a professional journal in the field of psychology.

\section{Contact information:}

If you have concerns or questions about this study, please contact the chair of UTC's Institutional Review Board, Dr. Amy Doolittle, at amy-doolittle@utc.edu or 423-425-5563 or the faculty supervisor for this study, Dr. Christopher Cunningham, at chriscunningham@utc.edu or 423-425-4264. By completing and returning this survey, you acknowledge that you have read this information and agree to participate in this research, with the knowledge that you are free to withdraw your participation at any time without penalty.

Thank you in advance for your assistance and participation.

Sincerely,

Lisa Brady

Christopher J. L. Cunningham, Ph.D.

The University of Tennessee Chattanooga

The Institutional Review Board of the University of Tennessee at Chattanooga

(FWA00004149)

has approved this research project \# 16-157 
I have read the preceding information and am willing to participate fully in this research.

Yes

No

Please answer the following questions about yourself:

Yes

Are you currently a full-time employee (i.e., working at least 34 hours per week) for an organization?

Are you currently enrolled as a full-time graduate student with additional paid work responsibilities (e.g.,

Graduate/Research/Teaching

Assistantship, internship,

part-/full-time work)?
No

$\bigcirc$<smiles>[O]</smiles>

When you talk to people, do you have the feeling that they don't understand you?

$\begin{array}{lllllll}1=\text { Never } & 2 & 3 & 4 & 5 & 6 & 7=\text { Always }\end{array}$

In the past, when you had to do something which depended upon cooperation with others, did you have the feeling that it:

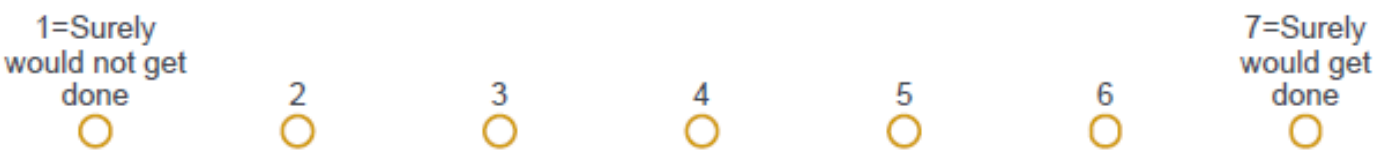

Think of the people with whom you come into contact daily, aside from the ones to whom you feel closest. How well do you know most of them?

$$
\begin{gathered}
1=\text { You feel } \\
\text { that they are } \\
\text { strangers }
\end{gathered}
$$

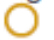

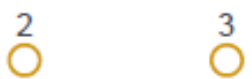

4

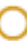

$7=$ You feel that you know them very well

Do you have the feeling that you don't really care about what goes on around you? 


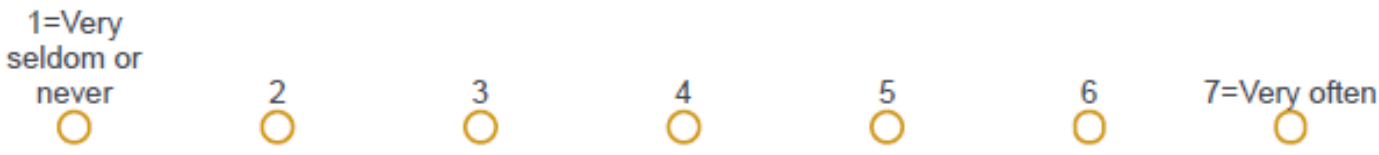

Has it happened in the past that you were surprised by the behavior of people whom you thought you knew well?

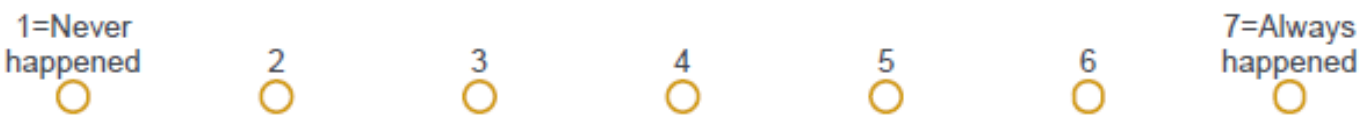

Has it happened that people whom you counted on disappointed you?

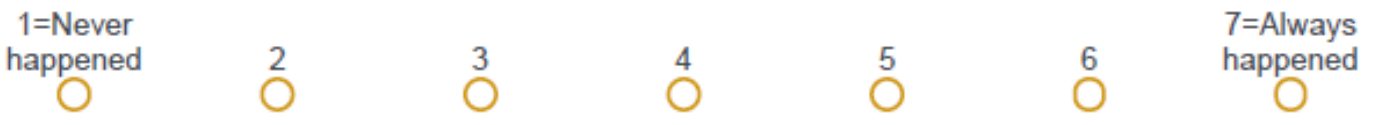

Life is:

$1=$ Full of

interest

${ }^{\circ}$

$\stackrel{3}{3} \quad \stackrel{3}{\circ}$

$\stackrel{4}{\bigcirc} \quad \stackrel{5}{\bigcirc}$

$7=$ Completely

routine

$\stackrel{6}{\circ}$

O

Until now your life has had:

$1=$ No clear

goals or

purpose at all

purpose

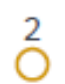

$\stackrel{2}{\bigcirc}$ $\stackrel{3}{\circ}$
7=Very clear goals and

purpose

$\stackrel{5}{\bigcirc}$

6

○

Do you have the feeling that you're being treated unfairly?
1=Very often
$\stackrel{2}{\circ}$
$\stackrel{3}{\circ}$
$\stackrel{4}{\bigcirc}$
$\stackrel{5}{\bigcirc}$
$\stackrel{6}{\circ}$
$7=$ Seldom or never 0

In the past ten years your life has been:

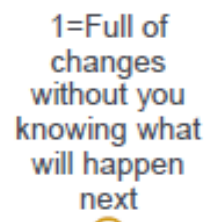

3

4

$\stackrel{5}{\bigcirc}$
$7=$ Completely consistent and clear 
Most of the things you do in the future will probably be:
$1=$ Completely
fascinating

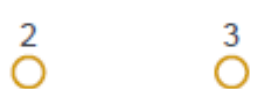
4
$\stackrel{5}{\bigcirc}$
7=Deadly
boring

Do you have the feeling that you are in an unfamiliar situation and don't know what to do?

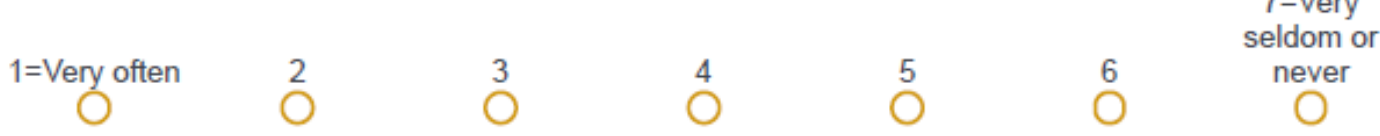

What best describes how you see life:

$$
\begin{aligned}
& 1=\text { One can } \\
& \text { always find a } \\
& \text { solution to } \\
& \text { painful things } \\
& \text { in life }
\end{aligned}
$$

2

3

$\bigcirc$
4

$\stackrel{5}{\circ}$
$7=$ There is no solution to painful things in life

6 $\mathrm{O}$

When you think about your life, you very often:

1=Feel how good it is to be alive

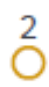

3

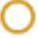

4

5
$7=$ Ask yourself why you exist at all

When you face a difficult problem, the choice of a solution is:

$\begin{gathered}\text { 1=Always } \\ \text { confusing and } \\ \text { hard to find }\end{gathered}$
$\bigcirc$

Doing the things you do every day is:

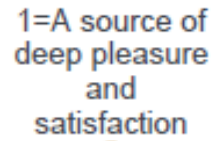

3

4

5
$7=$ A source of pain and boredom 
Your life in the future will probably be:

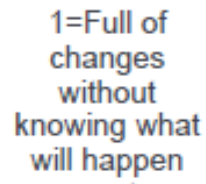

$\stackrel{2}{\circ}$ $\stackrel{3}{\circ}$

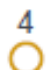

$7=$ Completely consistent and clear 0

When something unpleasant happened in the past your tendency was:

$$
\begin{gathered}
1={ }^{a} \text { To eat } \\
\text { yourself up" } \\
\text { about it }
\end{gathered}
$$
$\bigcirc$

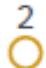

3

\section{$\stackrel{4}{8}$}

$7=$ To say "OK that's that, I have to live with it" and go

on

6

Do you have very mixed-up feelings and ideas?
1=Very often
2
3
$\stackrel{4}{6}$
$\stackrel{5}{\circ}$
6
$7=$ Seldom or never P

When you do something that gives you a good feeling:

$1=$ It's certain

that you'll go

on feeling good O

\section{2}

3

○ $\stackrel{4}{\bigcirc}$
$7=$ It's certain that something will happen to spoil the feeling

6 P

Does it happen that you have feelings inside you would rather not feel?

1=Very ofte

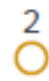

3

 $\stackrel{4}{\circ}$ $\stackrel{5}{\bigcirc}$
$7=$ Very seldom or never

You anticipate that your personal life in the future will be:

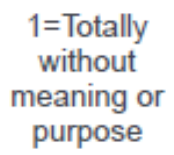

3
4

5
$7=$ Full of meaning and purpose 
Do you think that there will always be people whom you'll be able to count on in the future?

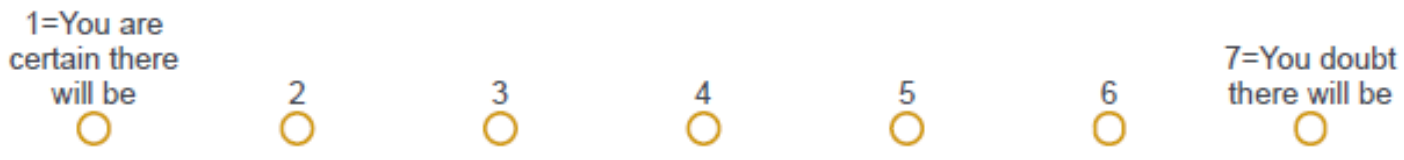

Does it happen that you have the feeling that you don't know exactly what's about to happen?

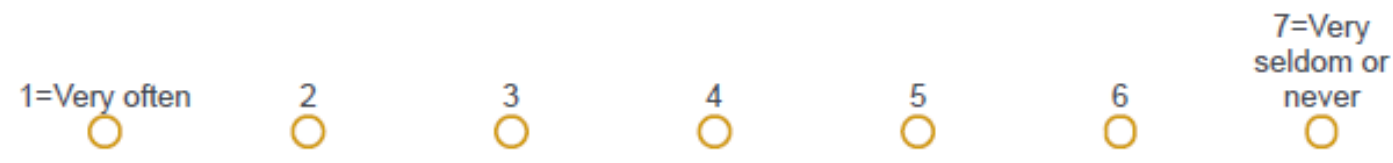

Many people - even those with a strong character - sometimes feel like sad sacks (losers) in certain situations. How often have you felt this way in the past?

$\begin{array}{cccccccc}1=\text { Never } & 2 & 3 & 4 & 5 & 6 & 7=\text { 7ery often }\end{array}$

When something happened, have you generally found that:

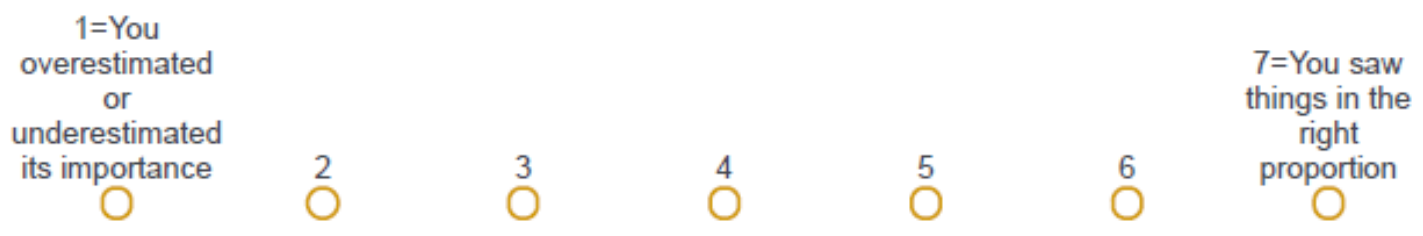

When you think of the difficulties you are likely to face in important aspects of your life, do you have the feeling that:

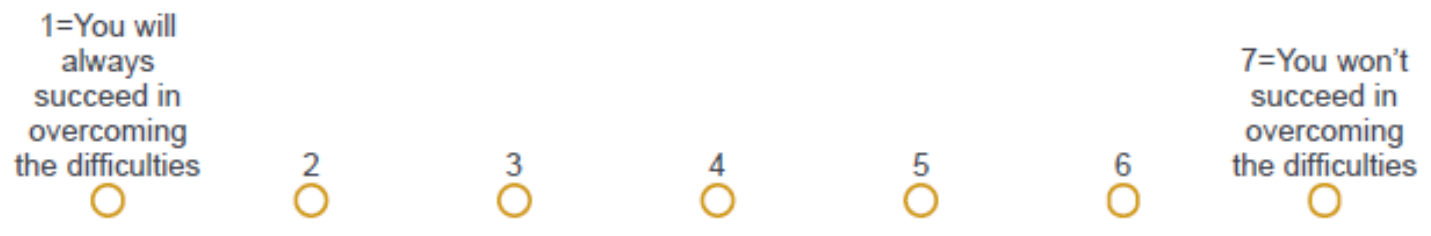

How often do you have the feeling that there's little meaning in the things you do in your daily life? 


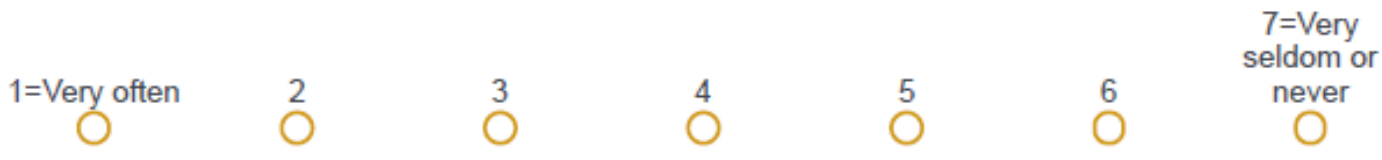

How often do you have feelings that you're not sure you can keep under control?

$\begin{array}{lllllll}\text { 1=Very often } & 2 & 3 & 4 & 5 & 6 & \begin{array}{c}\text { seldom or } \\ \text { never }\end{array} \\ & 0 & \bigcirc & \bigcirc & \bigcirc & \bigcirc & \bigcirc\end{array}$

How do you personally find your current job and work situation in general?

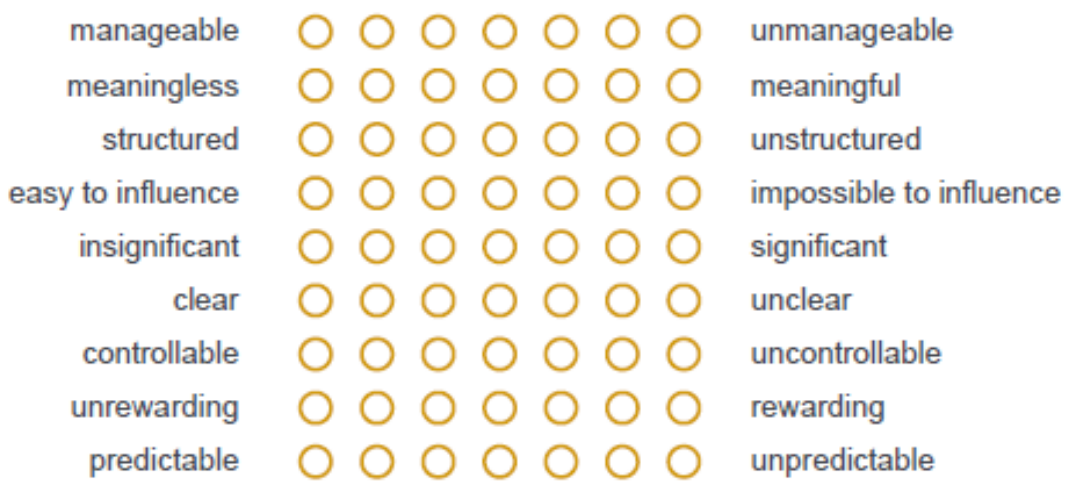

Do you find your job stressful? For each of the following words or phrases below, select the option that best matches your response:

\begin{tabular}{|c|c|c|c|}
\hline & Yes, it describes my job. & $\begin{array}{c}\text { No, it does not describe } \\
\text { my job. }\end{array}$ & ?, I cannot decide. \\
\hline Demanding & $\mathrm{O}$ & $\mathrm{O}$ & O \\
\hline Pressured & $\mathrm{O}$ & $\mathrm{O}$ & O \\
\hline Calm & $\mathrm{O}$ & $\mathrm{O}$ & $\mathrm{O}$ \\
\hline Many things stressful & $\mathrm{O}$ & $\mathrm{O}$ & $\mathrm{O}$ \\
\hline Hassled & $\mathrm{O}$ & $\bigcirc$ & $\mathrm{O}$ \\
\hline Nerve-racking & $\mathrm{O}$ & O & $\mathrm{O}$ \\
\hline $\begin{array}{l}\text { More stressful than l'd } \\
\text { like }\end{array}$ & $\mathrm{O}$ & ○ & O \\
\hline Overwhelming & $\mathrm{O}$ & $\bigcirc$ & O \\
\hline
\end{tabular}


"Work environment" = the environment in which you are working for compensation or experience. (For example: part-/full-time work, internship, graduate/research/teaching assistantship, clinical hours)

I understand how "work environment" is defined and applies to me.<smiles>[18O][Mg]</smiles>

Please identify the industry of your current "work environment" (as defined above). If the industry is not listed, please identify within the "other" box.
1 = Manufacturing
$6=$ Financial Activities
○ 2 = Retail
7 = Professional \& Business Services
$3=$ Wholesale
$8=$ Education and Health Services
4 = Transportation and Warehousing
9 = Leisure \& Hospitality
5 = Information
$10=$ Other:

In you current "work environment" (as defined above), what is your job title?

"Stressor" = a situation or event that requires some adaptive response on your part. (For example: a difficult coworker, a work interruption, or a new management style)

Please assess how encountering "stressors" (as defined above) in your "work environment" (as defined above) is likely to affect you.

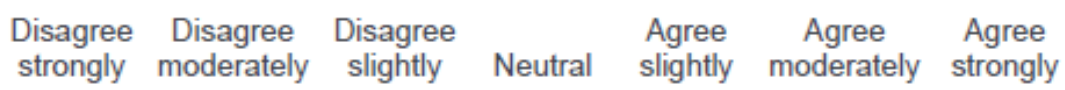

They will help me to learn a lot.

They will help me develop my skills.

They will show me I can do something new.

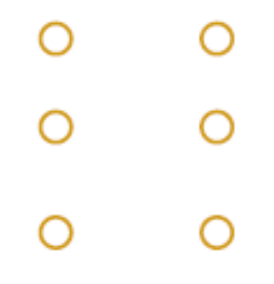


They will keep me focused on doing well.

$\begin{array}{cccccc}\begin{array}{c}\text { Disagree } \\ \text { strongly }\end{array} & \begin{array}{c}\text { Disagree } \\ \text { moderately }\end{array} & \begin{array}{c}\text { Disagree } \\ \text { slightly }\end{array} \text { Neutral } & \begin{array}{c}\text { Agree } \\ \text { slightly }\end{array} & \begin{array}{c}\text { Agree } \\ \text { moderately }\end{array} & \begin{array}{c}\text { Agree } \\ \text { strongly }\end{array}\end{array}$

They will hinder any achievements I might have.

They will restrict my capabilities.

They will limit how well I can do.

They will prevent me from mastering difficult aspects of the work.

They may be a negative experience for me.

They will result in negative outcomes.

They are going to have a negative

impact on me.

O slightly slightly moderately strongly

"Work environment" = the environment in which you are working for compensation or experience. (For example: part-ffull-time work, internship, graduate/research/teaching assistantship, clinical hours)

Indicate the PERCENTAGE OF TIME for which each of the following statements is TRUE about your current "work environment" (as defined above).

Click on the rating bar or move the slider to the position that indicates your response along a continuum ranging from $0 \%$ of the time (left) to $100 \%$ of the time (right).

$\begin{array}{lllllllllll}0 & 10 & 20 & 30 & 40 & 50 & 60 & 70 & 80 & 90 & 100\end{array}$

I have discretion in planning out my work and determining procedures in my work. 


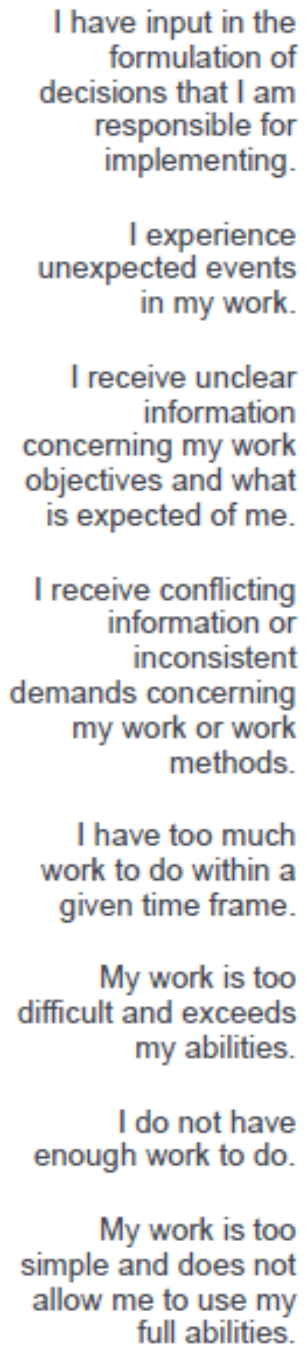

I have too much work to do within a given time frame.

My work is too difficult and exceeds my abilities.

I do not have enough work to do.

My work is too simple and does not allow me to use my full abilities.

"Work environment" = the environment in which you are working for compensation or experience. (For example: part-ffull-time work, internship, graduate/research/teaching assistantship, clinical hours)

Indicate the PERCENTAGE OF TIME for which each of the following statements is TRUE about your current "work environment" (as defined above). 
Click on the rating bar or move the slider to the position that indicates your response along a continuum ranging from $\underline{0 \%}$ of the time (left) to $100 \%$ of the time (right).

$\begin{array}{lllllllllll}0 & 10 & 20 & 30 & 40 & 50 & 60 & 70 & 80 & 90 & 100\end{array}$

I am responsible for the work of others

(e.g., others' morale, division of labor).

There is a lack of help and support from my colleagues.

There is a lack of help and support from my supervisors.

My work environment consists of negatively charged interactions between colleagues and peers.

My work environment consists of negatively charged interactions involving my supervisor.

The company bureaucracy (e.g., rules and procedures) at my organization prevents me from performing up to my capabilities.

The missing and/or lack of equipment and supplies at work prevents me from performing up to my capabilities.

I am uncertain about the security of my job in the future. 
Opportunities to learn, grow, or achieve

Responding to the next set of items will help us understand your opportunities for learning, growing, and/or otherwise achieving through your experiences at work. Before you proceed, please respond to the following question (so we know you're paying some attention):

I understand that this set of items is referring to situations in my work environment that would provide personal opportunities to learn, grow, or achieve.

Yes $\quad$ No

To what extent would the following situations in your work environment provide personal opportunities to learn. grow. or achieve?

Click on the rating bar or move the slider to the position that indicates your response along a continuum ranging from: $0=$ Not at all (left) to $100=$ Completely (right)

$\begin{array}{lllllllllll}0 & 10 & 20 & 30 & 40 & 50 & 60 & 70 & 80 & 90 & 100\end{array}$

\footnotetext{
Having discretion in planning out my work and determining my work procedures

Having input in the formulation of decisions that I am responsible for implementing

Experiencing unexpected events in my work

Receiving unclear information concerning my work objectives and what is expected of me
} 


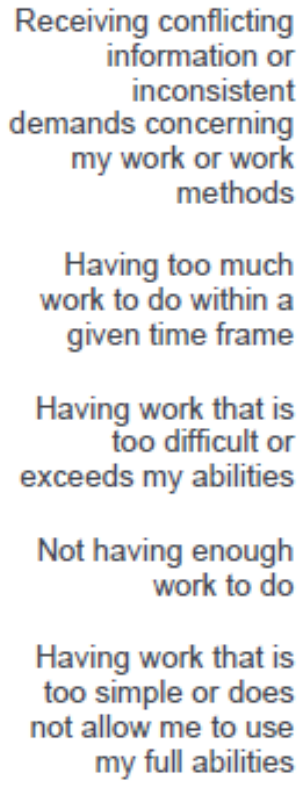

Having too much work to do within a given time frame

Having work that is too difficult or exceeds my abilities

Not having enough work to do

Having work that is too simple or does not allow me to use my full abilities

\section{Opportunities to learn, grow, or achieve (continued)}

To what extent would the following situations in your work environment provide personal opportunities to learn, grow, or achieve?

Click on the rating bar or move the slider to the position that indicates your response along a continuum ranging from: $0=N$ ot at all (left) to $100=$ Completely (right)

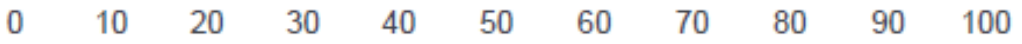

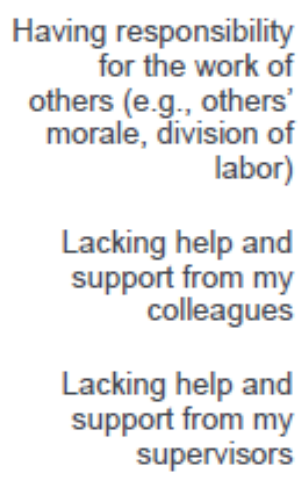




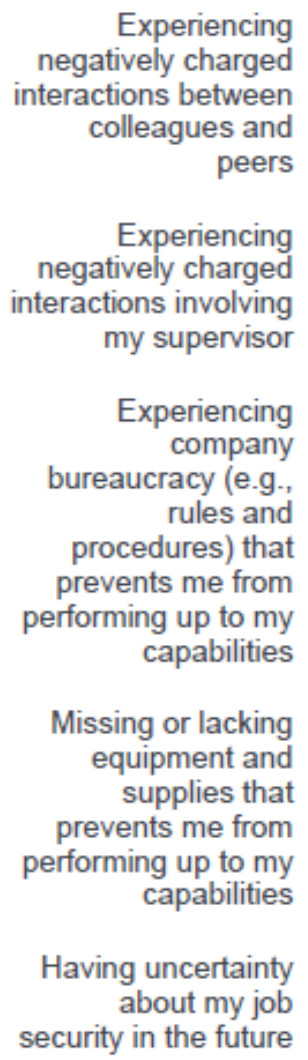

Having uncertainty about my job security in the future

\section{Restriction or obstruction of opportunities to learn, grow, or achieve}

Responding to the next set of items will help us understand the level of restrictions you perceive to your opportunities for learning, growing, and/or otherwise achieving through your experiences at work. Before you proceed, please respond to the following question (so we know you're paying some attention):

I understand that this set of items is referring to situations in my work environment that would RESTRICT OR OBSTRUCT my opportunities to learn, grow, or achieve.

$$
\text { Yes }
$$$$
\text { No }
$$ 
To what extent would the following situations in your work environment RESTRICT OR OBSTRUCT personal opportunities to learn, grow. or achieve?

Click on the rating bar or move the slider to the position that indicates your response along a continuum ranging from: $0=N o t$ at all (left) to $100=$ Completely (right)

$\begin{array}{lllllllllll}0 & 10 & 20 & 30 & 40 & 50 & 60 & 70 & 80 & 90 & 100\end{array}$

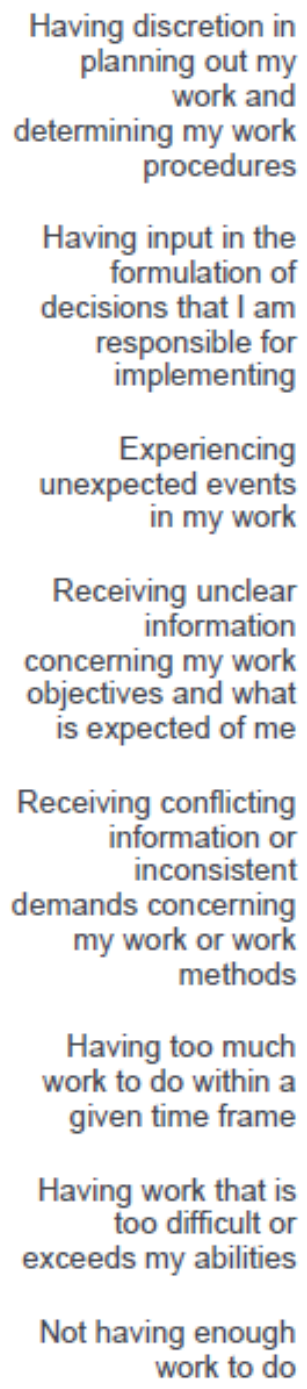

Receiving unclear information concerning my work objectives and what is expected of me

Receiving conflicting information or inconsistent demands concerning my work or work methods

Having too much work to do within a given time frame

Having work that is too difficult or exceeds my abilities

Not having enough work to do 
Having work that is too simple or does not allow me to use my full abilities

Restriction or obstruction of opportunities to learn, grow, or achieve (continued)

To what extent would the following situations in your work environment RESTRICT OR OBSTRUCT personal opportunities to learn, grow, or achieve?

Click on the rating bar or move the slider to the position that indicates your response along a continuum ranging from: $0=$ Not at all (left) to $100=$ Completely (right)

$\begin{array}{lllllllllll}0 & 10 & 20 & 30 & 40 & 50 & 60 & 70 & 80 & 90 & 100\end{array}$

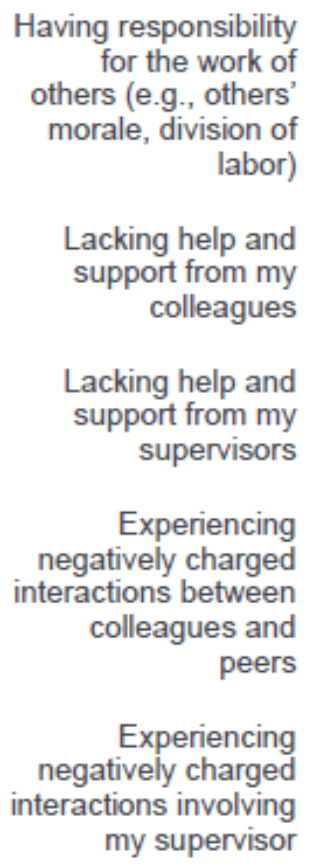




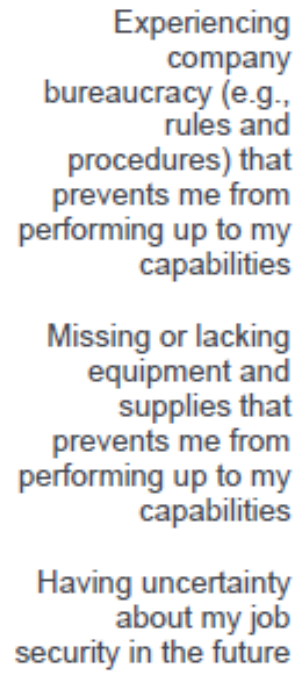

\section{Threats at work}

Responding to the next set of items will help us understand the level of potential threats (i.e., of harm, loss, or negative experience) you perceive at work. Before you proceed, please respond to the following question (so we know you're paying some attention):

I understand that this set of items is referring to situations in my work environment that would "POSE A THREAT" (e.g., cause future harm, loss, or negative experiences) to me.

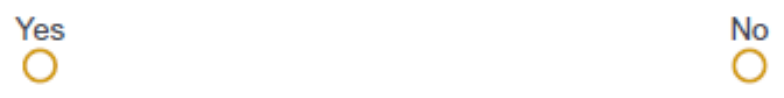

To what extent would the following situations in your work environment POSEA IHREAT to you?

Click on the rating bar or move the slider to the position that indicates your response along a continuum ranging from: $0=N o t$ at all (left) to $100=$ Completely (right)

$\begin{array}{lllllllllll}0 & 10 & 20 & 30 & 40 & 50 & 60 & 70 & 80 & 90 & 100\end{array}$




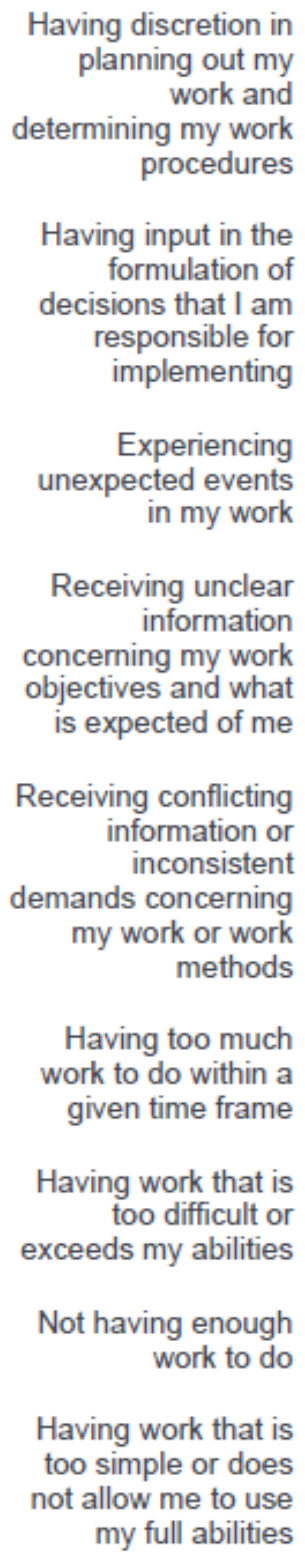

Receiving unclear information concerning my work objectives and what is expected of me

Receiving conflicting information or inconsistent demands concerning my work or work methods

Having too much work to do within a given time frame

Having work that is too difficult or exceeds my abilities

Not having enough work to do

Having work that is too simple or does not allow me to use my full abilities

\section{Threats at work (continued)}

To what extent would the following situations in your work environment POSEA THREAT to you? 
Click on the rating bar or move the slider to the position that indicates your response along a continuum ranging from: $0=N o t$ at all (left) to $100=$ Completely (right)

$\begin{array}{lllllllllll}0 & 10 & 20 & 30 & 40 & 50 & 60 & 70 & 80 & 90 & 100\end{array}$

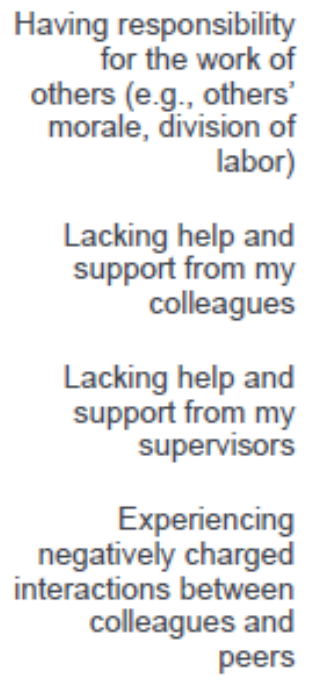

Experiencing negatively charged interactions between colleagues and

peers

Experiencing negatively charged interactions involving my supervisor

Experiencing company

bureaucracy (e.g., rules and

procedures) that prevents me from performing up to my capabilities

Missing or lacking equipment and supplies that

prevents me from performing up to my capabilities

Having uncertainty about my job security in the future 
Finally, please respond honestly and completely to the following questions. This information helps us understand and describe the overall sample of people who respond to this survey. These last few pages of questions really are the last part of this survey!

What is your sex?

Male

Female

O

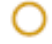

What is your current age? (enter only the number, example: 31 )

What is your marital status?

$2=$ In a committed (serious)

$1=$ Married or living relationship but not $3=$ Single, never as married married $\quad 4=$ Single, divorced $5=$ Single, widowed O $O$

What is your ethnicity? (select ethnicity with which you most closely identify)

$$
1=\text { Hispanic/Latino } \quad 2=\text { Non-Hispanic/Non-Latino }
$$

\begin{tabular}{|c|c|c|c|c|}
\hline $\begin{array}{c}2= \\
\text { Black/African }\end{array}$ & & $\begin{array}{l}4=\text { American } \quad 5=\text { Native } \\
\text { Indian/AlaskanHawaiian/Pacific }\end{array}$ & liddle & $7=$ \\
\hline American & $3=$ Asian & Islander & Eastern/Arab & More Races \\
\hline
\end{tabular}

What is your race? (select race with which you most closely identify)

What is the highest education level you have received?

1 = Some high school

2 = Completed high school

3 = Some college

4 = Associate's degree
5 = Bachelor's degree

6 = Some graduate school

7 = Master's degree

$8=$ Doctoral degree 
To how many children are you considered a parent? (report just the number of children, example: 3 )

How many children and adults depend on you for their care? (report just the number of children, example: 3 )

Please enter your annual household income (round to the nearest thousand; do not include commas).

If you have problems and are sad, is there anyone you can talk to? (You may select more than one option).
$1=$ Spouse
4 = Close friend
2 = Children
5 = Neighbor
$3=$ Relative
$6=$ Coworker

Enter the average number of hours you work each week. "Work" includes working for compensation or experience. (For example: part-/full-time work, internship, graduate/research/teaching assistantship, clinical hours)

If you have multiple "work" roles, add the hours together (round to the nearest amount of hours, example: 30 ).

How many individuals work directly under your leadership or supervision in your current position? (report just the number, example: 5) 
Enter the average number of years you have been working in your current position.

"Work" includes working for compensation, job experience, or course credit.

(For example: part-/full-time work, internship, graduate/research/teaching

assistantship, clinical hours)

(Please round to the nearest number of years, example: 2)

How many years have you worked full-time (i.e., at least 34 hours per week)? (round to the nearest year)

If you have never worked full-time, please enter 0. 


\section{VITA}

Lisa Brady was born in Covington, Louisiana on November 1, 1990 to Claude and Rose Brady. Her brother and sister are Danny and Laura Brady. She was raised in Folsom, LA and attended Saint Peter Catholic School for elementary school and Saint Scholastica Academy for high school. Upon graduation, she attended The University of Alabama in Tuscaloosa, AL where she studied Psychology and minored in Spanish. While at UA, Lisa conducted research on the psychological effects of physical activity in fifth-graders, which eventually impacted her decision to pursue a master's degree. After graduating in 2013, she worked for two years before attending The University of Tennessee at Chattanooga for graduate school. At UTC Lisa worked as a graduate assistant for the Counseling Center and the Graduate School. She graduated in May 2017 with a Masters of Science degree in Industrial-Organizational Psychology. 